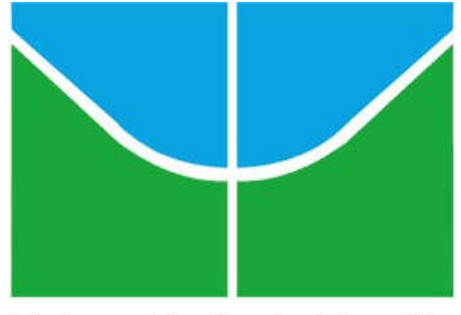

Universidade de Brasília
Universidade de Brasília

Instituto de Ciências Biológicas

Programa de Pós-Graduação em Biologia Animal

Janaína Gomes Penteado

\title{
ESTUDO DA EFICÁCIA DA ALUMÍNIO-CLORO-FTALOCIANINA EM MICELAS APLICADA NA TERAPIA FOTODINÂMICA EM CÉLULAS DE MELANOMA MURINO
}

\author{
Brasília, DF
}

Março, 2016 


\section{Janaína Gomes Penteado}

\section{ESTUDO DA EFICÁCIA DA ALUMÍNIO-CLORO- FTALOCIANINA EM MICELAS APLICADA NA TERAPIA FOTODINÂMICA EM CÉLULAS DE MELANOMA MURINO}

Dissertação de mestrado apresentada ao Programa de Pós-Graduação em Biologia Animal da Universidade de Brasília, como requisito para obtenção do título de Mestre em Biologia Animal.

Orientadora: Profa. Dra. Mônica Pereira Garcia 
Dedico esse trabalho ao meu filho Gabriel, aos meus pais, aos meus avós e aos meus irmãos. 


\section{AGRADECIMENTOS}

Agradeço primeiramente a Deus pelo presente da vida, a saúde, a força e coragem para prosseguir no caminho correto da virtude, da tolerância, da generosidade, da amizade, do companheirismo, da gentileza, do respeito e do afeto. Obrigada meu Deus, por colocar tantas pessoas boas e outras nem tão boas, para que também pudesse apender com elas!

Ao meu filho Gabriel....que desde sempre me apoia,me ajuda, me ajuda a enfrentar a vida, pois como filho, nunca reclamou das horas ausentes, dos dias intermináveis de trabalho, do meu cansaço. Agradeço a você meu filho, por todo o amor e compreensão as dificuldades que nós enfrentamos todos os dias!

Ao meu companheiro Sebastian..... Inside these pages you just hold me and I won't ever let you go. We made these memories for ourselves and wait for me to come home!!!

Aos meus pais, Nelson e Rosângela, por ser essa fonte inesgotável de apoio, motivação e amor. Obrigada por todas as oportunidades proporcionadas durante toda a minha vida...

Aos meus irmãos, Pablo e Felipe, minhas cunhadas, Isabella e Maria Luíza pelo apoio, carinho e amizade de sempre!

Aos meus avós, Armando e Rosicler, obrigada por terem me apoiado e dado o exemplo de luta, integridade e amor.

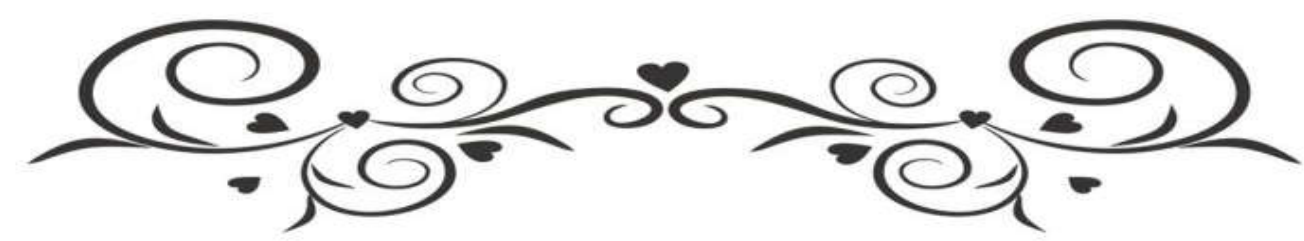

A construção de todo o meu trabalho de mestrado, foi possível por causa de pessoas especiais. Foram tantos grãos de areia colocados por tantas pessoas realmente me sinto extremamente grata por ter tido a oportunidade de conviver com pessoas que não 
mediram os esforços para me ajudar e pelo conhecimento que cada um generosamente compartilhou comigo.

Agradeço a Professora Mônica Garcia, pela importante oportunidade que me foi concedida. Pela paciência, compreensão, apoio e confiança. Agradeço por todos os ensinamentos, pela amizade e pela confiança no meu trabalho. Obrigada Professora!!!! A pessoa a qual tenho um profundo carinho e respeito, uma profunda gratidão por todo o apoio, carinho, gentileza, amizade, por engrandecer o meu espírito compartilhando toda sua experiência e sabedoria, por tornar meus dias mais alegres com um sorriso e um abraço cotidianos. Obrigada D. Zélia!! A Sra. não sabe o quão importante é e sempre será em minha vida.

À minha amada florzinha Rayane Ganassin, muito obrigada. Deus colocou você em minha vida e por isso sou muito grata. Hoje tenho uma filha de coração! Te amo PiuPiu!!!

À querida Dra. Maria Luiza Fascineli pela alegria, amizade, disponibilidade e por todo o apoio.

À Professora Graziella Joanitti pela enorme paciência, gentileza e amizade. Posso dizer que encontrei a pessoa mais afável e gentil do mundo e que seu exemplo profissional é algo que me orgulha e emociona.

Aos Professores Aline Pic-Taylor, Carla, César Grisólia, Professora Susana Milhomen, agradeço por todo o carinho, apoio e respeito.

À Profesora Zulmira Lacava, que em muitos momentos difíceis, me ajudou com sua docura e delicadeza. Obrigada Professora por todas as palvavras de carinho, incentivo. Pelos ensinamentos e por ser uma Lady. 
Aos meus amados amigos, Mayara Simolely, Ludmila David, Khélida Loiane, Luíza Yanny, Wània Guimarães, José filho, Ana Gouvea, Déborah Santos, muito obrigada por todo o amor, compreensão, carinho e ajuda que me foram ofertados. As palavras são poucas pra descrever, as ações também não são suficientemente grandes para agradecer por toda a amizade. Amo vocês!

À Karen Rappa Py-Daniel..."Eu tenho tanto pra lhe falar mas com palavras não sei dizer. Como é grande o meu amor por você! Nunca se esqueça, nem um segundo que eu tenho o amor maior do mundo. Como é grande o meu amor por você!"

E às demais pessoas que fizeram parte desta empreitada, muito obrigada!!!! 
Felicidade é quando o que você pensa, o que você diz e o que você faz estão em harmonia. "Mahatma Gandhi" 


\section{RESUMO}

Entre os tipos de câncer de pele, o melanoma é responsável por $4 \%$ dos casos. É o mais agressivo, por possuir um alto potencial metastático. Como proposta para um tratamento mais efeciente e que cause menos danos estéticos, foi utilizada a Terapia Fotodinâmica (TFD) como um sistema que proporcionasse uma futura utilização por via tópica. No presente trabalho as micelas de Pluronic ${ }^{\circledR}$ F127 contendo 1,5 e 10 $\mu \mathrm{g} / \mathrm{mL}$ do fotossensibilizante alumínio-cloro-ftalocianina (NP F127/AICIPc), as micelas foram utilizadas para investigar os efeitos da TFD em células de melanoma murino. NP F127/AICIPc foram avaliadas quanto a sua estabilidade e caracterização fotofísica e fotoquímica $\mathrm{O}$ diâmetro hidrodinâmico $(\mathrm{DH})$ médio de NP F127/AICIPc com $1 \mu \mathrm{g} / \mathrm{mL}$ de ALCLPc foi de $22 \mathrm{~nm} ; 42,03 \mathrm{~nm}$ para $5 \mu \mathrm{g} / \mathrm{mL}$ e 152,9 nm para 10 $\mu \mathrm{g} / \mathrm{mL}$ a $\sim 25^{\circ} \mathrm{C}$. O índice de polidispersão foi 0,43 para $1 \mu \mathrm{g} / \mathrm{mL} ; 0,68$ para $5 \mu \mathrm{g} / \mathrm{mL}$; 0,37 para $10 \mu \mathrm{g} / \mathrm{mL}$, e o potencial zeta (PZ) de $-2,71 \mathrm{mV}$ para $1 \mu \mathrm{g} / \mathrm{mL} ;-0,11 \mathrm{mV}$ para $5 \mu \mathrm{g} / \mathrm{mL}$ e $-0,58 \mathrm{mV}$ para $10 \mu \mathrm{g} / \mathrm{mL}$, mostrando que as micelas são polidispersas. NP F127/AICIPc apresentou máxima absorbância a $670 \mathrm{~nm}$ e fluorescencia a $680 \mathrm{~nm}$. Duas linhagens celulares foram utilizadas: B16F10 (melanoma murino) e B16F10FF (melanoma murino modificadas com FireFly Luciferase). Somente a irradiação com a luz LED ou a exposição das células a diferentes concentrações de NP F127/AICIPc não causaram toxicidade em ambas as linhagens celulares. Quando aplicada a TFD com fluência de $85,1 \mathrm{~J} / \mathrm{cm}^{2}$. Os resultados de citotoxicidade da NP F127/AICIPc, com vários tempos de incubação, mostrou uma maior eficácia em células B16F10 do que em células B16F10FF. A concentração de $1 \mu \mathrm{g} / \mathrm{mL} ; 5 \mu \mathrm{g} / \mathrm{mL} ; 10 \mu \mathrm{g} / \mathrm{mL}$ mostraram-se mais eficaz no tempo de incubação de 20 e 25 minutos para as células B16F10. Pelo mesmo tempo de exposição de 25 minutos, as células B16F10FF mostraram-se mais resistentes ao tratamento. A citotoxicidade sem irradiação e com irradiação do LED mostrou que as micelas não causaram toxicidade em ambas as linhagens celulares. As células expostas à NP F127/AICIPc nas concentração de $1 \mu \mathrm{g} / \mathrm{mL} ; 5$ $\mu \mathrm{g} / \mathrm{mL} ; 10 \mu \mathrm{g} / \mathrm{mL}$ por 15, 20 e 25 minutos e irradiadas com a fluência de $85,1 \mathrm{~J} / \mathrm{cm}^{2}$, mostraram que células B16F10 tratadas com a NP F127/AICIPc $10 \mu \mathrm{g} / \mathrm{mL}$ 
apresentaram viabilidade de $25 \%$, enquanto as células B16F10FF sob as mesmas condições apresentaram viabilidade de $64 \%$. A citotoxicidade nas células B16F10FF foi de $7 \%$ para o tempo de incubação de 20 minutos e de 3 a $4 \%$ nos tempos de 15 e 25 minutos, quando estas células sofream duas incubações (24-48 horas) e duas aplicações de TFD (24-48 horas). Pode-se concluir então que, a NP F127/AICIPc apresentou características fotofísicas e fotoquímicas favoráveis para o seu uso da TFD.

Palavras chave: fotossensibilizante, Pluronic ${ }^{\circledR}$ F127, nanobiotecnologia, câncer de pele, nanopartículas poliméricas. 


\section{ABSTRACT}

Melanoma accounts for $4 \%$ of cases among skin cancer types. But it is the most aggressive with a high metastatic potential. Photodynamic therapy (PDT) was used as an alternative efficient and less damage inducing treatment in comparison to chemotherapy for topical application. In the present work Pluronic ${ }^{\circledR}$ F127 micelles containing 1,5 and $10 \mu \mathrm{g} / \mathrm{mL}$ of the photosensitizer aluminum-chlorophthalotocyanine (F127/AICIPC). The micelles were used to investigate the effects of PDT on murine melanoma cells. Their stability, photophysical characteristics and photochemistry was evaluated. The hydrodynamic diameter for the micelles carrying $1 \mu \mathrm{g} / \mathrm{mL}, 5 \mu \mathrm{g} / \mathrm{mL}$ and $10 \mu \mathrm{g} / \mathrm{mL}$ was $22 \mathrm{~nm}, 42.04 \mathrm{~nm}$ and $152.9 \mathrm{~nm}$ respectively. The poly dispersity index for the micelles with $1 \mathrm{mg} / \mathrm{mL}, 5 \mathrm{mg} / \mathrm{mL}$ and $10 \mathrm{mg} / \mathrm{mL}$ were 0.43 , 0.68 and 0.37 respectively. The zeta potential for the micelles with $1 \mu \mathrm{g} / \mathrm{mL}, 5 \mu \mathrm{g} / \mathrm{mL}$ and $10 \mu \mathrm{g} / \mathrm{mL}$ F127/AICIPc were $-2.7 \mathrm{mV},-0.11 \mathrm{mV}$ and $-0.58 \mathrm{mV}$. The micelles showed maximum absorbance at $670 \mathrm{~nm}$ and fluorescence at $680 \mathrm{~nm}$. Two cell lines were evaluated B16F10 (murine melanoma) and B16F10FF (murine melanoma modified with firefly luciferase). The irradiation of LED with light or with different concentration of F127 / AICIPc did not cause toxicity to both cell lines when the PDT fluent was $85.1 \mathrm{~J} / \mathrm{cm}^{2}$. The cytotoxity results of the micelles F127/AICIPc at various incubation times was more prominent with B16F10 than B16F10FF. The concentration of $1 \mu \mathrm{g} / \mathrm{mL}, 5 \mu \mathrm{g} / \mathrm{mL}$ and $10 \mu \mathrm{g} / \mathrm{mL}$ were more effective against B16F10 cells when incubated for 20 minutes and 25 minutes. However, for B16F10FF cells they were resistant to treatment after 25 minutes of incubation. The cytotoxicity with either irradiation or without showed that the micelles did not cause toxicity to both cells. Upon exposure to $1 \mu \mathrm{g} / \mathrm{mL}, 5 \mu \mathrm{g} / \mathrm{mL}$ and $10 \mu \mathrm{g} / \mathrm{mL}$ for 15,20 and 25 minutes and irradiation of fluency $85.1 \mathrm{~J} / \mathrm{cm}^{2}$ B16F10 presented a viability of $25 \%$ while B16F10FF had $64 \%$. After incubation of 15,20 and 25 minutes the cytotoxicity of B16F10FF cells was $3 \%, 7 \%$ and $4 \%$ respectively when the cells were incubated (24-48 hours) and PDT was applied twice (24-48 hours). It can be concluded that the micelles with F127 / AICIPC presented photophysical and photochemical characteristics favorable for use in photodynamic therapy. 
Keywords: photosensitizer, Pluronic ${ }^{\circledR}$ F127, nanobiotechnology, skin cancer, polymeric nanoparticles. 


\section{LISTA DE FIGURAS}

Figura 01. Estimativas para o ano de 2016 do número de casos novos de câncer por regiões, no Brasil. Fonte: INCA, 2016

Figura 02. Estimativas de novos casos de câncer para o ano de 2016, no Brasil, segundo sexo e localização primária. Fonte: INCA, 2016.

Figura 03. Fases de progressão histopatológica na transformação de melanócitos.

Figura 04. Fotocarcinogênese do melanoma.

Figura 05. Diagrama dos níveis de energia de Jablonski para a terapia fotodinâmica (TFD).

Figura 06. Estrutura química da Alumínio-Cloro-Ftalocianina.

Figura 07. Diferentes vetores usados em nanomedicina aplicada ao transporte de fármacos, sendo alguns já utilizados em terapia clínica e pré-clínica

Figura 08. Representação de micelas de copolímeros em bloco de Pluronic ${ }^{\circledR}$ F127.

Figura 09. Esquema de preparação das amostras de micelas de pluronic F127 com diferentes concentrações de Alumínio-Cloro-Ftalocianina (AICIPc).

Figura 10. Esquema dos ensaios in vitro com células B16F10 e B16F10FF.

Figura 11. Esquema ilustrativo do LED em fluxo laminar utilizando um suporte de metal. Diodo emissor de luz com 85,1 J/cm2 (LED) para irradiação de placa de 96 poços com células B16 F10 e B16F10FF.

Figura 12. Variação do Diâmetro Hidrodinâmico (DH) por dispersão dinâmica de luz (DLS) das micelas de Pluronic ${ }^{\circledR} \mathrm{F} 127$, com ou sem fotossensibilizante armazenadas, sob as condições de $4{ }^{\circ} \mathrm{C}, \sim 25^{\circ} \mathrm{C}$ e $37^{\circ} \mathrm{C}$. 
Figura 13. Variação do Índice de Polidispersão (IPD) por dispersão dinâmica de luz (DLS) das micelas de Pluronic ${ }^{\circledR} \mathrm{F} 127$, com ou sem fotossensibilizante armazenadas, sob as condições de $4{ }^{\circ} \mathrm{C}, \sim 25^{\circ} \mathrm{C}$ e $37^{\circ} \mathrm{C}$.

Figura 14. Variação do Potencial Zeta $(\mathrm{Pz})$ por dispersão de luz eletroforética das micelas de Pluronic ${ }^{\circledR} \mathrm{F} 127$, com ou sem fotossensibilizante armazenadas, sob as condições de $4{ }^{\circ} \mathrm{C}, \sim 25^{\circ} \mathrm{C}$ e $37^{\circ} \mathrm{C}$.

Figura 15. Variação do Potencial Hidrogeniônico $(\mathrm{pH})$ das micelas de Pluronic ${ }^{\circledR}$ F127, com ou sem fotossensibilizante armazenadas, sob as condições de $4{ }^{\circ} \mathrm{C}(\mathbf{A})$, $\sim 25^{\circ} \mathrm{C}(\mathbf{B})$ e $37^{\circ} \mathrm{C}(\mathbf{C})$ ao longo de 42 dias.

Figura 16. Espectro de absorção e de emissão de fluorescência com excitação a $360 \mathrm{~nm}$ de micelas de Pluronic $^{\circledR} \mathrm{F} 127$ sem fotossensibilizante e com $1 \mu \mathrm{g} / \mathrm{mL}$ de Alumínio-Cloro-Ftalocianina (NP F127/AICIPc), após a preparação.

Figura 17. Valores percentuais da densidade óptica referente ao decaimento da absorbância do 1,3-difenil-isobenzofurano (DBF) em relação ao tempo de exposição ao LED de micelas de Pluronic ${ }^{\circledR}$ F127 sem (NP F127) e com diferentes concentrações de Alumínio-Cloro-Ftalocianina.

Figura 18. Viabilidade de células de melanoma murino (B16F10) e de melanoma modificada para expressar luciferase (B16F10FF) expostas ou não por 10 minutos de irradiação de diodo emissor de luz (LED) a $85,1 \mathrm{~J} / \mathrm{cm}^{2}$, avaliada posteriormente pelo método MTT.

Figura 19. Viabilidade de células de melanoma murino, B16F10 (A) e de melanoma modificada para expressar luciferase, B16F10FF $(B)$ expostas ou não (controle) às formulações de micelas de Pluronic $^{\circledR}$ F127 com diferentes concentrações de Alumínio-Cloro-Ftalocianina.

Figura 20. Viabilidade de células de melanoma murino, B16F10 (A) e de melanoma modificada para expressar luciferase, B16F10FF (B) expostas ou não (controle) às formulações de micelas de Pluronic $^{\circledR}$ F127 com diferentes concentrações de Alumínio-Cloro-Ftalocianina. 
Figura 21. Viabilidade de células de melanoma murino modificadas para expressar luciferase, B16F10FF expostas ou não (controle) às formulações de micelas de Pluronic ${ }^{\circledR}$ F127 com diferentes concentrações de Alumínio-Cloro-Ftalocianina.

Figura 22. Perfil de resposta das células B16F10FF, dependente de tempo após o tratamento com TFD, gerado pelo RTCA. 


\section{LISTA DE TABELAS}

Tabela 01: Taxas brutas de incidência por 100 mil habitantes e o número de casos novos de câncer, segundo sexo e localização primária*, para o ano de 2016.

Tabela 02: Lista de Equipamentos utilizados.

Tabela 03: Lista de Materiais utilizados.

Tabela 04: Reagentes utilizados.

Tabela 05: Relação da preparação das amostras de micelas de pluronic F127 com diferentes concentrações de Alumínio-Cloro-Ftalocianina (AICIPC).

Tabela 06: Valores médios do diâmetro hidrodinâmico (DH), do índice de polidispersão (IPD), do potencial zeta $(\mathrm{Pz})$ e do potencial hidrogeniônico $(\mathrm{pH})$ logo após o preraro. 


\section{LISTA DE ABREVIAÇÕES E SIGLAS}

${ }_{1} \mathrm{O}_{2} \quad$ Oxigênio singleto

AICIPc Alumínio-Cloro-Ftalocianina

ANOVA Análise de variância

CMC Concentração Micelar Crítica

CMT Temperatura Crítica de Miscelização

DMEM Dulbecco's Modified Eagle Medium

DMSO Dimetilsulfóxido

ERO Espécies reativas de oxigênio

FS Fotossensibilizante

LED Diodo emissor de luz

MTT Brometo de 3(4,5 dimetiltiazol-2il)-

2,5-difenil-tetrazólio

PBS Tampão fosfato salina

SFB Soro fetal bovino

TFD Terapia Fotodinâmica 


\section{Sumário}

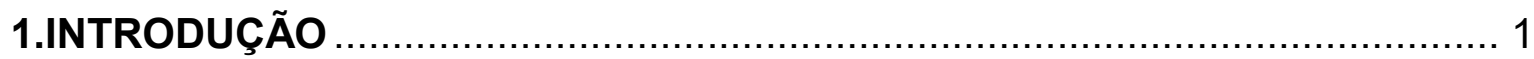

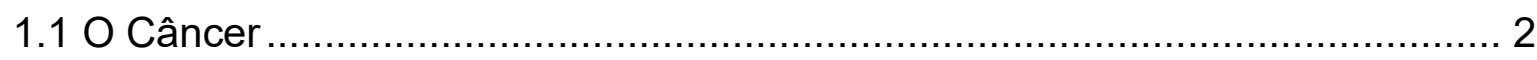

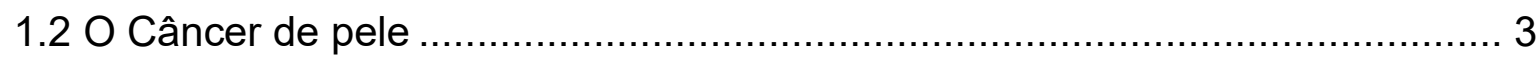

1.3 A origem do câncer de pele não-melanoma e melanoma ............................ 8

1.4 Os tratamentos para o melanoma.............................................................

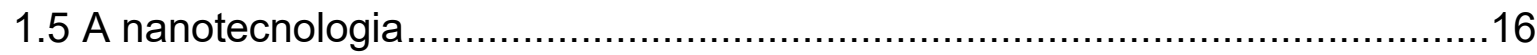

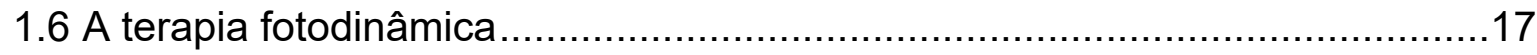

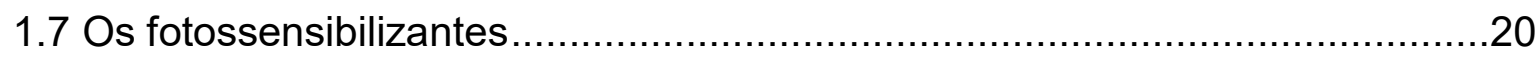

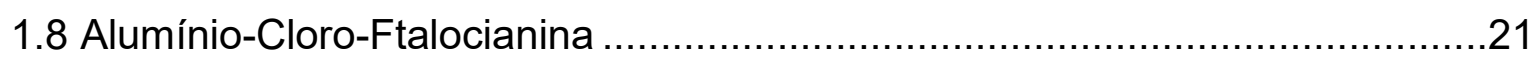

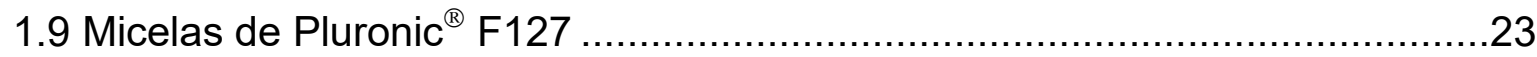

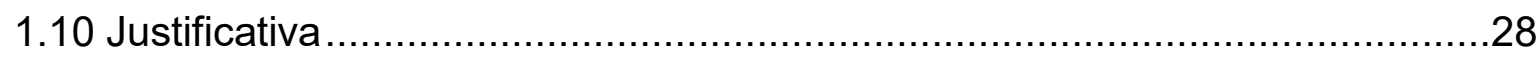

2. OBJETIVO

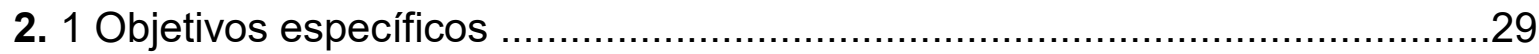

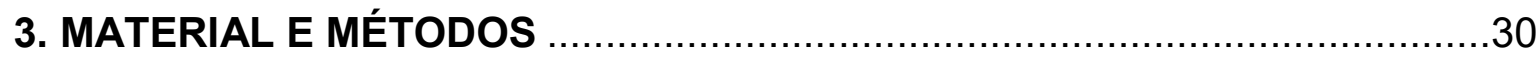

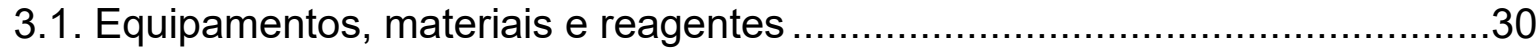

3.2. Preparação de micelas de Pluronic ${ }^{\circledR} F 127$ com alumínio-cloro-ftalocianina

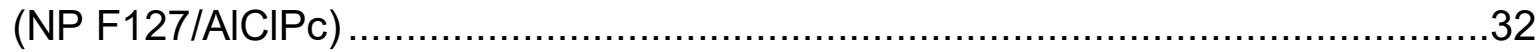

3.3. Caracterização e avaliação da estabilidade coloidal das micelas de Pluronic ${ }^{\circledR}$ F127 com Aluminio-Cloro-Ftalocianina (NP F127/AICIPc)

3.4. Caracterização fotofísica das micelas de Pluronic ${ }^{\circledR}$ F127 com Aluminio-Cloro-

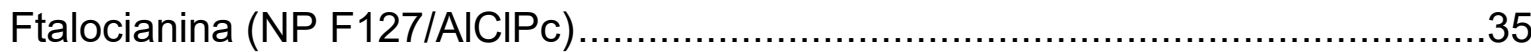

3.5. Avaliação da Geração de Oxigênio Singleto pelas micelas de Pluronic ${ }^{\circledR} F 127$ com Aluminio-Cloro-Ftalocianina (NP F127/AICIPc) ............................................

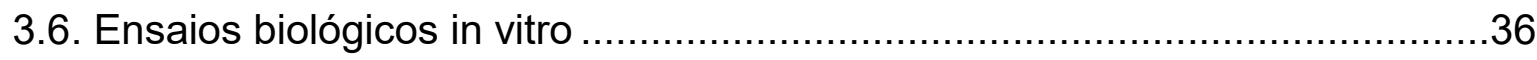

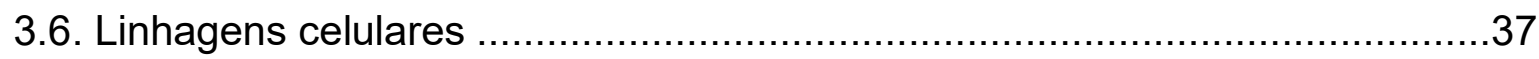

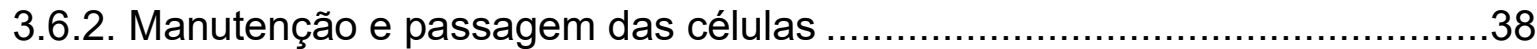

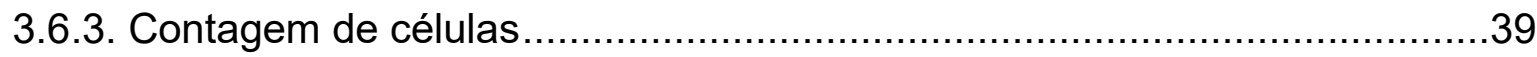

3.6.4. Avaliação da viabilidade celular pelo ensaio do MTT .................................39

3.6.5. A fonte luminosa LED (Light Emitting Diode) ......................................40

3.6.6. Determinação da toxicidade do LED na viabilidade celular........................41 
3.6.7. Determinação da toxicidade das micelas de Pluronic ${ }^{\circledR}$ F127 com AluminioCloro-Ftalocianina (NP F127/AICIPc) na viabilidade celular.

3.6.8. Avaliação da Terapia Fotodinâmica mediada por micelas de Pluronic ${ }^{\circledR} \mathrm{F} 127$ com Aluminio-Cloro-Ftalocianina (NP F127/AICIPC) ...

3.6.9. Avaliação da eficácia de duas sessões de Terapia Fotodinâmica mediada por micelas de Pluronic ${ }^{\circledR}$ F127 com Aluminio-Cloro-Ftalocianina (NP F127/AICIPc)

3.6.10. Avaliação da eficácia de duas sessões de Terapia Fotodinâmica mediada por micelas de Pluronic ${ }^{\circledR}$ F127 com Aluminio-Cloro-Ftalocianina (NP F127/AICIPc), analisando a dinâmica de proliferação celular. .45

3.7. Análise Estatística 46

4. RESULTADOS .46

4.1. Caracterização coloidal das micelas de Pluronic ${ }^{\circledR} F 127$ com Alumínio-CloroFtalocianina (NP F127/AICIPC).

4.2. Avaliação da estabilidade coloidal das micelas de Pluronic ${ }^{\circledR} F 127$ com Alumínio-Cloro-Ftalocianina (NP F127/AICIPc)....

4.3. Caracterização fotofísica das micelas de Pluronic ${ }^{\circledR}$ F127 com Alumínio-CloroFtalocianina (NP F127/AICIPc). .55 4.4. Avaliação da Geração de Oxigênio Singleto pelas micelas de Pluronic ${ }^{\circledR}$ F127 com Alumínio-Cloro-Ftalocianina (NP F127/AICIPc) .....................................56

4.5. Determinação da toxicidade do LED na viabilidade celular. .58

4.6. Determinação da toxicidade das micelas de Pluronic ${ }^{\circledR} F 127$ com AlumínioCloro-Ftalocianina (NP F127/AICIPc) na viabilidade celular.

4.7. Avaliação da Terapia Fotodinâmica mediada por micelas de Pluronic ${ }^{\circledR} F 127$ com Alumínio-Cloro-Ftalocianina (NP F127/AICIPc) ...

4.8. Avaliação da eficácia de duas sessões de Terapia Fotodinâmica mediada por micelas de Pluronic ${ }^{\circledR}$ F127 com Alumínio-Cloro-Ftalocianina (NP F127/AICIPc)...64 4.9. Avaliação da eficácia de duas sessões de Terapia Fotodinâmica mediada por micelas de Pluronic ${ }^{\circledR}$ F127 com Alumínio-Cloro-Ftalocianina (NP F127/AICIPC), analisando a dinâmica de proliferação celular.

5. DISCUSSÃO

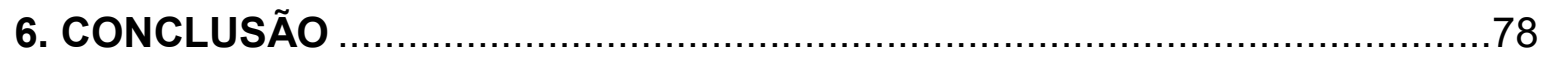

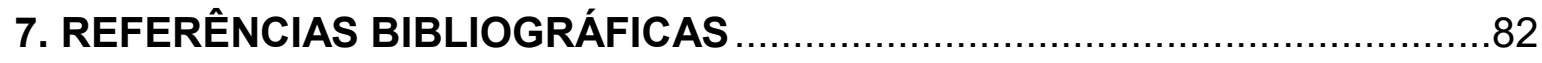




\section{INTRODUÇÃO}

O câncer de pele apesar de ter uma baixa incidência, tem uma alta letalidade devido ao alto potencial metastático destas células tumorais. O tratamento padrão é a remoção cirúrgica do melanoma primário, seguido ou não, da quimioterapia, ou radioterapia ou ainda imunoterapia. Dentre as principais drogas citotóxicas utilizadas no tratamento do melanoma está a Dacarbazina e a Temozolida, que muitas vezes são utilizados em combinação com Carmustina, Cisplatina, Vimblastina ou Tamoxifeno. Embora esta terapêutica continue tendo imensas desvantagens, pois estes agentes quimioterapêuticos convencionais são bastante inespecíficos, com uma elevada toxicidade, resultando em uma dose subterapêutica (devido à baixa acumulação tumoral), o protocolo de quimioterapia para o melanoma ainda é utilizado.

A terapia fotodinâmica (TFD) é uma modalidade terapêutica não invasiva, de baixo custo e que não necessita de internação do paciente e surge como um promissor tratamento contra o câncer. Juntamente com a TFD, a utilização do fotossensibilizante Alumínio-Cloro-Ftalocianina carreado por micelas de Pluronic ${ }^{\circledR}$ F127 torna-se uma ferramenta potencial, pois se trata de uma terapia com alta eficiência que surge como uma importante inovação na terapia antineoplásica. Fotosensibilizantes carreados por um sistema nanoestruturado possuem vantagens farmacocinéticas bastante relevantes, como o nível de absorção do FS em células tumorais potencializandos pela TFD. O Pluronic ${ }^{\circledR}$ possue boa biocompatibilidade e biodegradação. Fatores que contribuem para uma terapia mais eficiente e com menos efeitos colaterais. Assim, a avaliação da eficácia deste sistema no tratamento do melanoma é de fundamental importância na busca de novas e melhores modalidades terapêuticas. 


\subsection{Câncer}

O câncer é o nome utilizado para designar um grupo de mais de 100 doenças que têm em comum a proliferação celular desordenada. Segundo HANAHAN \& WEINBERG (2000), como a formação de um tumor envolve múltiplas etapas, ao longo desse processo as células passam por alterações genéticas que incluem: insensibilidade aos sinais inibidores do crescimento; potencial infinito de replicação; evasão à morte celular e dos mecanismos de defesa imune; indução persistente da angiogênese e capacidade de invadir e colonizar outros tecidos, ou seja, originar metástases.

A capacidade de fundar colônias em locais distantes é a característica mais perigosa do câncer, pois as metástases são responsáveis por $90 \%$ dos óbitos causados pelo câncer (HANAHAN \& WEINBERG, 2000). Segundo CILLIA e colaboradores (2010) análises moleculares demonstraram que muitos cânceres surgem de lesões precursoras não neoplásicas que já possuem algumas das mutações necessárias para se estabelecer plenamente um câncer. Estes mesmos autores afirmam que os cânceres sofrem seleção darwiniana, pois essas mutações proporcionam vantagens seletivas às células da lesão precursora.

O crescimento excessivo, a invasividade local e a capacidade de formar metástases distantes, são atributos fenotípicos das neoplasias malignas, bem como, a capacidade de se tornarem mais agressivos e adquirem maior potencial maligno após algum período de tempo. Esse fenômeno é denominado de progressão tumoral e não é representado pelo aumento do tamanho do tumor (KANG et al, 2000).

Estudos clínicos e experimentais revelam que a malignidade tumoral muitas vezes está associada à progressão celular e a heterogeneidade associadas, resultando em múltiplas mutações que se acumulam independentemente em diferentes gerações de células. Essas passam a apresentar a capacidade de invadir outros tecidos, taxa de crescimento diferenciada, capacidade metastática, responsividade hormonal e suscetibilidade à drogas antineoplásicas (COGHLIN \& MURRAY, 2010). 
Esta doença representa um enorme problema de saúde pública, pois é a principal causa de morte nos países desenvolvidos economicamente e é a segunda principal causa de morte em países em desenvolvimento (JEMAL et al, 2011). No ano 2014, o número de pessoas diagnosticadas com câncer no mundo somou mais de 14 milhões e é esperado que o número de novos casos aumente em $70 \%$ ao longo dos próximos 20 anos (FORMAN et al, 2014) e espera-se para 2030, 27 milhões de casos novos de câncer (World Cancer Report, 2008). Segundo a Organização Mundial de Saúde, a maior incidência do câncer vem sendo impulsionada por uma rápida mudança no estilo de vida dos países em desenvolvimento, que cada vez mais se assemelha ao dos países industrializados e o impacto do câncer nesses países, corresponderá a $80 \%$ dos mais de 20 milhões de casos novos estimados para 2025 (OMS, 2016); (WHO, 2015).

\subsection{Câncer de pele}

A estimativa para o Brasil em 2016-2017, aponta a ocorrência de 600 mil novos casos de câncer. À exceção do câncer de pele não melanoma ( 180 mil casos novos), ocorrerão cerca de 420 mil casos novos de câncer. O perfil epidemiológico observado assemelha-se ao da América Latina e do Caribe. Os tipos mais frequentes de câncer em homens serão o de próstata $(28,6 \%)$, de pulmão $(8,1 \%)$, intestino $(7,8 \%)$, de estômago $(6,0 \%)$ e da cavidade oral $(5,2 \%)$. Nas mulheres, os cânceres de mama $(28,1 \%)$, de intestino $(8,6 \%)$, de colo do útero $(7,9 \%)$, de pulmão $(5,3 \%)$ e de estômago ( $3,7 \%)$ serão os principais.

Dentre os diferentes tipos de câncer, destacam-se os de pele, devido, principalmente, a sua alta incidência na população; no Brasil, o câncer de pele representa 25\% de todos os cânceres (Sociedade Brasileira de Dermatologia, 2015). Segundo as estimativas 2016/2017 do Instituto Nacional de Câncer José Alencar Gomes da Silva, INCA, as estimativas de incidência de câncer de pele, no Brasil, são de 596 mil casos de câncer. Entre os homens, são esperados 295.200 casos, e entre as mulheres, 300.800 (Figura 01). 


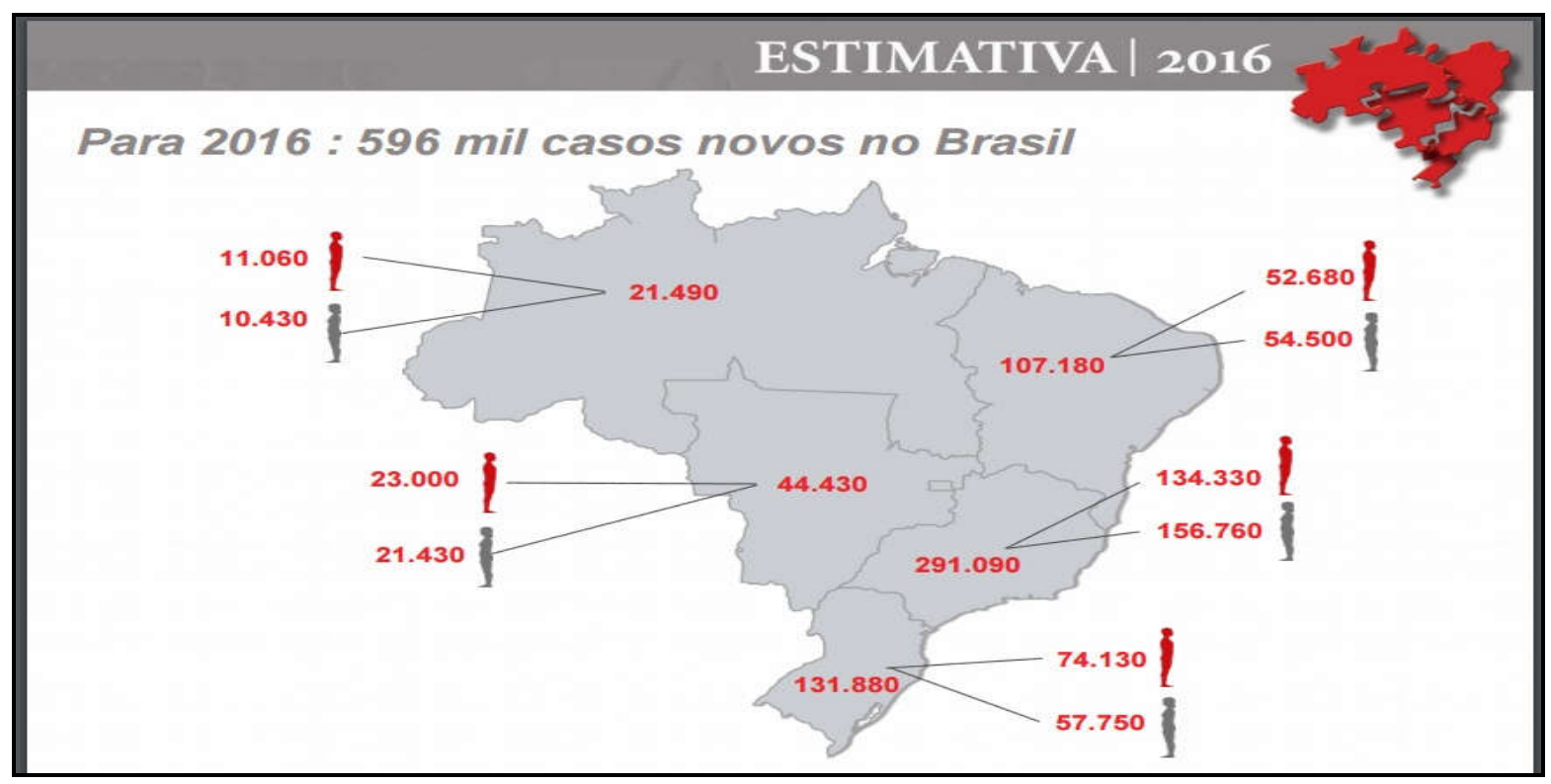

Figura 01. Estimativas para o ano de 2016 do número de casos novos de câncer por regiões, no Brasil. Fonte: INCA, 2016

Existem três tipos de câncer de pele. O carcinoma basocelular ( $C B C)$, também conhecido como carcinoma de células basais; o carcinoma espinocelular (CEC), também conhecido como carcinoma de células escamosas e o melanoma. O CBC é o mais prevalente dentre todos os tipos de câncer, porém com baixa letalidade, podendo ser curado em caso de detecção precoce. Os CBCs se desenvolvem principalmente em áreas do corpo mais expostas ao sol, como face, ombros e costas, sendo que a exposição ao sol não é o único fator desencadeador da doença. O tipo mais encontrado de $\mathrm{CBC}$ é o nódulo-ulcerativo, que se traduz como uma pápula vermelha brilhosa, com crosta central, que pode sangrar com facilidade (Sociedade Brasileira de Dermatologia, 2014).

O CEC é o segundo mais prevalente dos cânceres de pele. Pode se desenvolver em todas as partes do corpo, embora seja mais comum nas áreas expostas ao sol. O local da lesão apresenta enrugamento, mudanças na pigmentação e perda da elasticidade. Coloração avermelhada, ferida espessa e descamativa de difícil cicatrização são algumas das características desta malignidade. O CBC e o CEC, juntos, são denominados câncer de pele nãomelanoma (Sociedade Brasileira de Dermatologia, 2014). 
De acordo com o INCA (2016), a estimativa de novos casos de câncer de pele melanoma em homens a estimativa é de 990 novos casos na região Sul; 1.160 novos casos em homens e 1.100 em mulheres na região Sudeste; 210 novos casos em homens e 150 em mulheres na região Centro-Oeste; 550 novos casos em homens e 390 em mulheres na região Nordeste; 90 novos casos em homens e 70 em mulheres na região Norte (Figura 2).

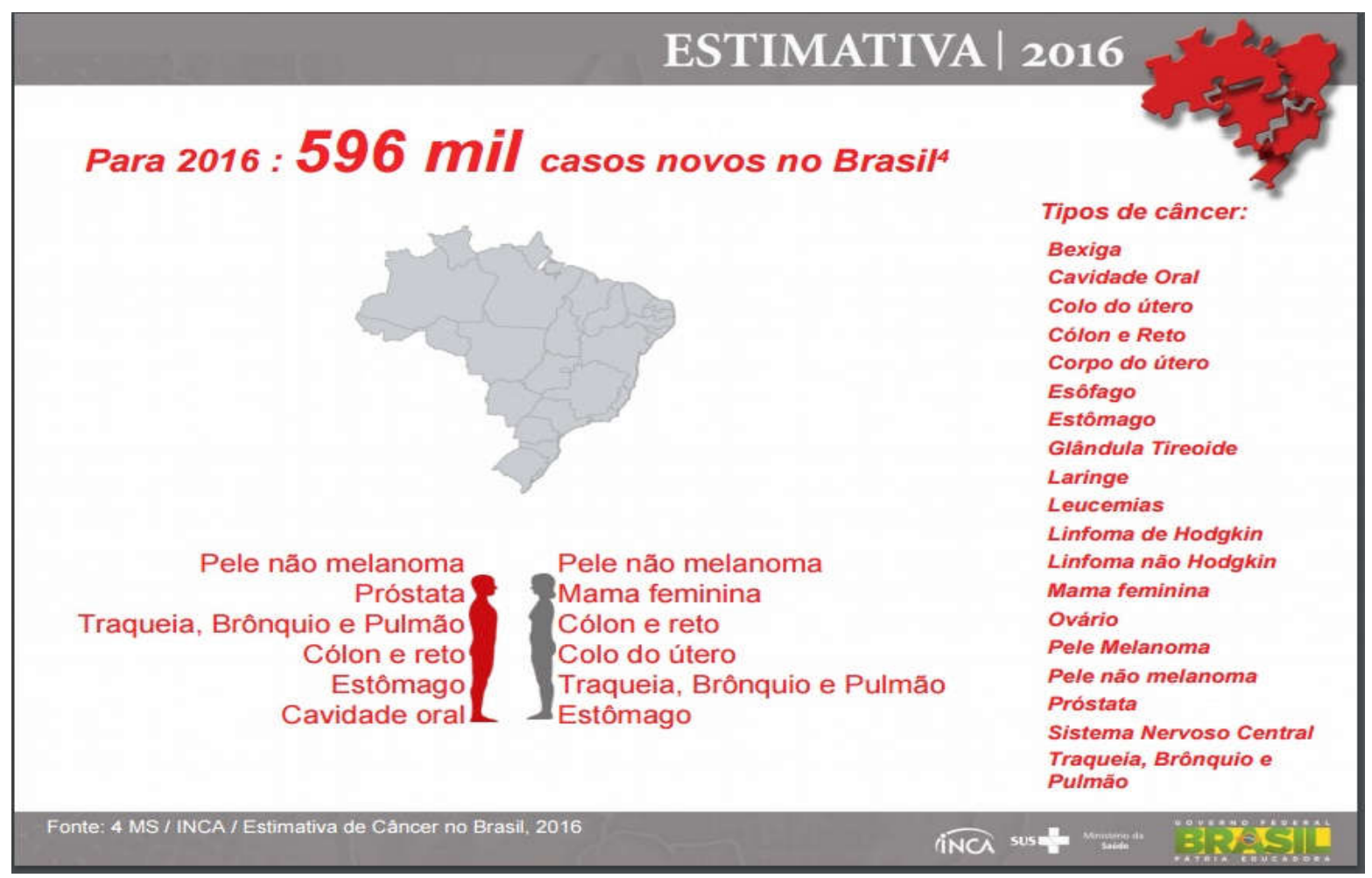

Figura 02. Estimativas de novos casos de câncer para o ano de 2016, no Brasil, segundo sexo e localização primária. Fonte: INCA, 2016.

O melanoma, cuja incidência, apesar de baixa, menos de $4 \%$ dos casos no Brasil, (Sociedade Brasileira de Cirurgia Dermatológica, 2015) sua incidência está aumentando no mundo inteiro e constitui a maioria dos casos de morte por câncer de pele; sendo o de pior prognóstico. Em geral, tem a aparência de um nevo ou de um sinal na pele, em tons acastanhados ou enegrecidos. Porém, mudam de cor, de formato ou de tamanho, e podem causar sangramento. No Brasil, cerca de $0,15 \%$ de todas as neoplasias malignas correspondem ao melanoma, com uma estimativa de 
$3.000(1,4 \%)$ novos casos em homens e $2.670(1,3 \%)$ em mulheres para o ano de 2016 (Tabela 01). As mais altas taxas de incidência de câncer de pele, melanoma e não melanoma, foram observadas em países com população caucasiana. Mais de $80 \%$ dos diagnósticos de melanomas e $65 \%$ dos óbitos por esse câncer foram verificados na Oceania, Europa e América do Norte (INCA, 2016).

Tabela 1: Taxas brutas de incidência por 100 mil habitantes e o número de casos novos de câncer, segundo sexo e localização primária*, para o ano de 2016.

\begin{tabular}{|c|c|c|c|c|c|c|c|c|}
\hline \multirow{4}{*}{$\begin{array}{l}\text { Localizaçáo Primária } \\
\text { Heoplasia Maligna }\end{array}$} & \multicolumn{8}{|c|}{ Estimativa dos Cassos Noves: } \\
\hline & \multicolumn{4}{|c|}{ Homeas } & \multicolumn{4}{|c|}{ Mulhares } \\
\hline & \multicolumn{2}{|c|}{ Esthdios } & \multicolumn{2}{|c|}{ Capitalis } & \multicolumn{2}{|c|}{ Etadados } & \multicolumn{2}{|c|}{ Capliale } \\
\hline & Cssos & Tara Bruta & Casos & Tara Bruta & Casos & Taxa Bruta & Casos & Taxe Bruts \\
\hline Prostata & 61.200 & 61,82 & 13.940 & 64,93 & . & - & - & - \\
\hline Mama Femirina: & . & - & - & $\cdot$ & 57.960 & 56,20 & 18.990 & 79,37 \\
\hline Colo do Utero: & . & - & - & - & 16.340 & 15,85 & 4.550 & 19,07 \\
\hline Traqueia, Bronquio e Pulmáo & 17.330 & 17,49 & 4.430 & 20,59 & 10.890 & 10,54 & 3.230 & 13,49 \\
\hline Colon e Reto & 16.660 & 16,84 & 5.560 & 25,80 & 17.620 & 17,10 & 6.210 & 25,95 \\
\hline Estômago & 12.920 & 13,04 & 3.130 & 14,54 & 7.600 & 7,37 & 2.180 & 9,07 \\
\hline Cavidade Oral & 11.140 & 11,27 & 2.780 & 12,95 & 4.350 & 4,21 & 1.230 & 5,04 \\
\hline Laringe & 6.360 & 6,43 & 1.600 & 7,50 & 990 & 0,94 & 320 & 0,97 \\
\hline Beoiga: & 7.200 & 7.26 & 2.110 & 9,79 & 2.470 & 2,39 & 830 & 3.21 \\
\hline Esofago & 7.950 & 8,04 & 1.460 & 6.75 & 2.860 & 2,76 & 610 & 2,27 \\
\hline Oxario & . & . & - & - & 6.150 & 5,95 & 2.170 & 8,92 \\
\hline Lintoma de Fodgkin & 1.460 & 1,46 & 450 & 1,74 & 1.010 & 0,93 & 400 & 1,33 \\
\hline Lintoma náo Hodgkin & 5.210 & 5,27 & 1.550 & 7,15 & 5.030 & 4,88 & 1.670 & 7,02 \\
\hline Gländuh Tireoide & 1.090 & 1,08 & 350 & 1,27 & 5.870 & 5,70 & 1.800 & 7,46 \\
\hline Sistema Nervoso Central & 5.440 & 5,50 & 1.290 & 5,86 & 4.830 & 4,68 & 1.250 & 5,20 \\
\hline Leucenias & 5.540 & 5,63 & 1.370 & 6,38 & 4.530 & 4,38 & 1.180 & 4,88 \\
\hline Cospo do Utero & . & . & - & . & 6.960 & 6,74 & 2.530 & 10,47 \\
\hline Pela Malanoma & 3.000 & 3,03 & 840 & 3,86 & 2.670 & 2,59 & 740 & 2,96 \\
\hline Outras Locallzaçoes & 51.850 & 52,38 & 11.890 & 55,45 & 47.840 & 46,36 & 11.820 & 49,33 \\
\hline Subtotal & 214.350 & 216,48 & 52.750 & 245,63 & 205.960 & 199,57 & 61.710 & 257,55 \\
\hline Pele nda Melanoma & 80.850 & 81,66 & 17.370 & 80,90 & 94.910 & 91,98 & 21.910 & 91,65 \\
\hline Tothas as Meoplanias & 295.200 & 298,13 & 70.120 & 325,51 & 300.870 & 291,54 & 83.620 & 348,99 \\
\hline
\end{tabular}

*Números arredondados para máltiplos de 10.

O melanoma é definido por critérios patológicos e clínicos. Histologicamente, a classificação de melanoma reflete a localização e/ou a profundidade (Figura 03). Por exemplo, o melanoma in situ, é caracterizado pelo padrão de crescimento radial que é primariamente confinado à epiderme. Em contraste, a "fase de crescimento vertical" de um melanoma maligno denota uma transição para uma condição mais 
agressiva e letal, a qual é caracterizada pela invasão do tumor na derme e hipoderme e muitas vezes é indicativo de metástase para locais distantes (ELDER, 1987). A busca de prognósticos futuros da doença metastática e sobrevivência tem sido uma grande preocupação. Entre os muitos fatores avaliados, a espessura total do tumor independente surgiu como o mais determinante prognóstico para melanomas não-metastáticos (CHIN et al., 1998).

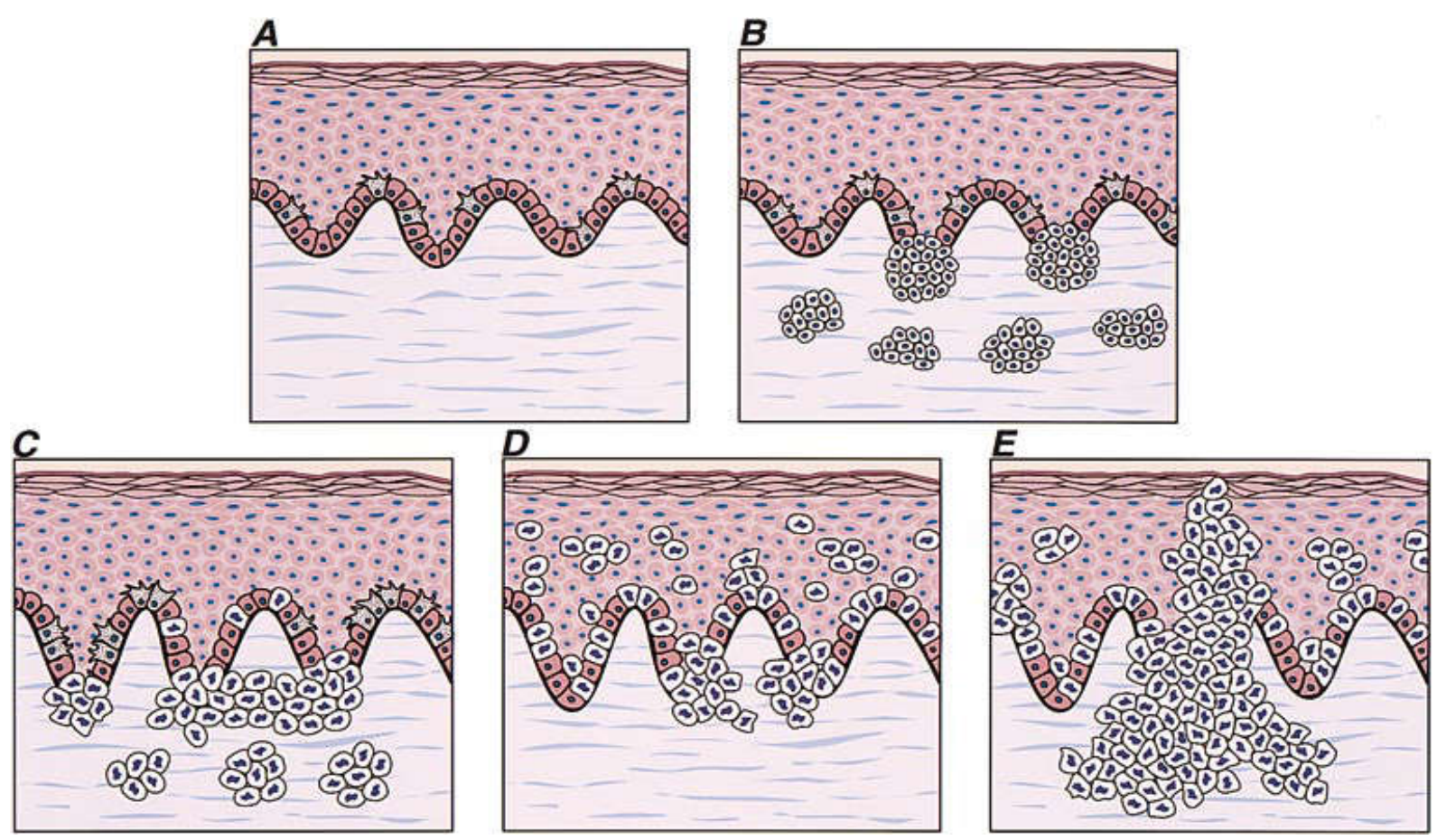

Figura 03. Fases de progressão histopatológica na transformação de melanócitos. A- Pele normal. Observa-se a distribuição uniforme dos melanócitos dendríticos em toda a camada basal. B- Proliferação benigna dos melanócitos. C- Displasia de melanócitos. Nota-se a irregularidade e grandes melanócitos atípicos em um nevo displásico. D- No melanoma in situ, fase de crescimento radial (RGP). Observam-se células individuais na camada superior da epiderme (propagação). E- Melanoma maligno, fase de crescimento vertical (VGP). Adaptado de CHIN et al., 1998.

Apesar da longa história de reconhecimento clínico e enormes esforços na classificação patológica, a precisão de mecanismos patogênicos que conduzem ao melanoma ainda não são bem compreendidos. Várias características desta doença 
forneceram evidências para etiologias genéticas e epigenéticas. É igualmente claro que a cor da pele é um importante modificador do risco de melanoma. Indivíduos de pele escura têm substancialmente menores riscos de incidência de melanoma do que as populações de pele clara, dados os mesmos níveis de exposição aos raios UV (BARNHILL et al., 1993).

A chance de cura dessa doença está diretamente relacionada ao diagnóstico e ao tratamento no início do seu desenvolvimento, quando ainda afeta apenas a pele, o chamado melanoma primário. Em estágios mais avançados, ele pode se espalhar para outros órgãos, o chamado melanoma metastático, tornando a cura difícil, sendo que somente $12 \%$ dos pacientes com melanoma metastático sobrevivem mais de cinco anos (FIGUEIREDO et al, 2003).

\subsection{A origem do câncer de pele não-melanoma e melanoma}

O Melanoma é derivado da transformação maligna de melanócitos, células fenotipicamente importantes, pois são responsáveis pela produção da melanina, promovendo a pigmentação da pele e pelos. A melanina além de contribuir para a tonalidade cutânea, também confere proteção direta aos danos causados pela radiação solar UV (TSAO et al, 2015). Os melanócitos são células dendríticas, embriologicamente derivadas dos melanoblastos, os quais se originam da crista neural. Após o fechamento do tubo neural, estas células migram para diversos locais: olhos (epitélio pigmentar da retina, iris e coróide), ouvidos (estrias vasculares), sistema nervoso central (leptomeninges), matriz dos pelos, mucosas e pele (BOISSY,1988; SULLAIMON \& KITCHELL , 2003).

$\mathrm{Na}$ pele (Figura 04) a melanina é doada aos queratinócitos, as células localizadas na região basal da epiderme, onde os seus núcleos estão protegidos fisicamente contra a radiação ultravioleta. Este tipo de radiação ao incidir nos melanócitos pode ser absorvida pela melanina; quando isso acontece ela transfere parte de sua energia para moléculas de oxigênio, gerando oxigênio singleto (LIANG et al, 2014), estes por sua vez podem oxidar biomoléculas tais como lipídios, proteínas, aminoácidos, ácidos nucleicos e carboidratos (RONSEIN et al, 
2006; PLAETZER et al, 2003; ROBERTSON et al, 2010), desencadeando cascatas de sinalização celular que ativam ou inibem a apoptose ou induzem a proliferação.

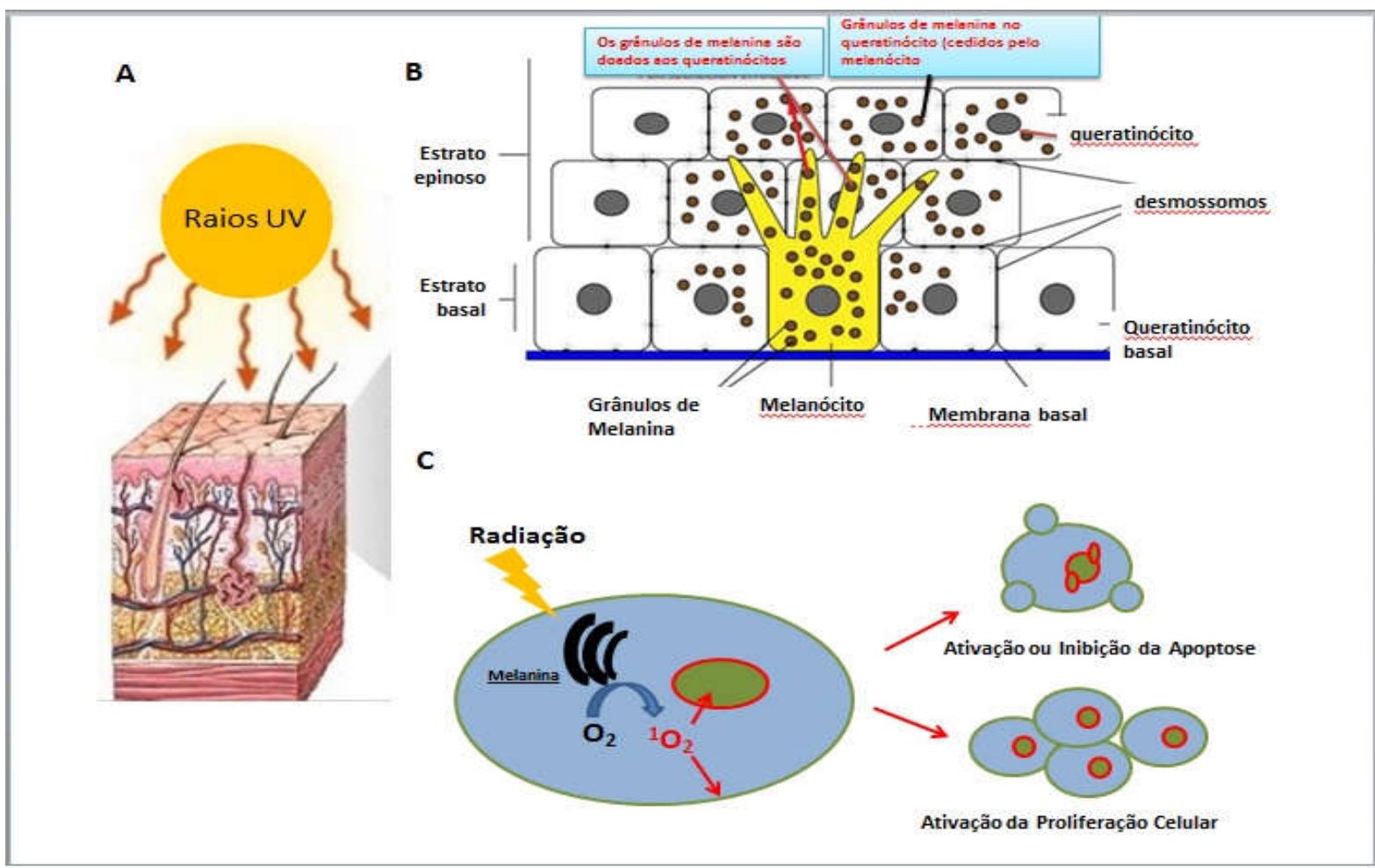

Figura 04. Fotocarcinogênese do melanoma. A- A radiação solar ultravioleta (UV) incidindo sobre a pele. B- Esquema da epiderme, destacando o melanócito basal contendo grânulos de melanina e doando estes grânulos aos queratinócitos do estrato espinoso. C- Se o processo de biossíntese da melanina pelos melanócitos não é regulada adequadamente ou após exposição excessiva da radiação UV, ocorre um aumento da geração do estresse oxidativo e de subprodutos metabólicos que podem ser citotóxicos ao DNA causando genotoxicidade e/ou danos mutagênicos nos melanócitos afetados, favorecendo assim a transformação inicial da célula e posteriormente, promovendo a progressão para o câncer a partir da transformação dos melanócitos (Adaptado de Baptista et al, 2014 e WarszawikHendzel et al, 2014).

Além disso, há evidências de que, se o processo de biossíntese da melanina pelos melanócitos não é regulado adequadamente, a capacidade de geração de 
estresse oxidativo e subprodutos metabólicos é aumentada. Estes subprodutos podem ser citotóxicos ao DNA causando genotoxicidade e/ou danos mutagênicos nos melanócitos afetados, favorecendo assim a transformação inicial da célula e posteriormente, promovendo a progressão para o câncer a partir da transformação dos melanócitos (WARSZAWIK-HENDZEL et al, 2014).

O melanócito por meio da expansão de seu citoplasma, pode interagir com até 36 queratinócitos simultaneamente. Os melanossomos, organela específica que sintetiza o pigmento melanina, transferem dos melacócitos para os queratinócitos das camadas suprabasais, gerando o processo de pigmentação da epiderme (HAASS \& HERLYN, 2005; LI \& HERLYN, 2001). Após o processo de adesão, os queratinócitos controlam o crescimento e a expressão de receptores na superfície dos melanócitos. Uma grande parte dos melanomas surge dentro da epiderme (melanoma in situ) invadindo então a membrana basal. Células tumorais podem se evadir dos queratinócitos pelos seguintes mecanismos: 1) diminuição da expressão de importantes receptores na comunicação de queratinócitos, como a E-caderina, Pcaderina desmogleína e conexinas, geradas por fatores de crescimento como o fator de crescimento dos hepatócitos, a endotelina-1, fator de crescimento derivado das plaquetas e produzidos por fibroblastos e queratinócitos; 2) a N- caderina, MELCAM e proteína-1 de zonula de oclusão, que agem na regulação de receptores e moléculas de sinalização importantes para interações de células de melanomamelanoma e fibroblasto-melanoma; 3) a desrugulação de morfógenos como os resceptores de Notch e seus ligantes; 4) gerear a perda de ancoragem à membrana basal devido a alteração de moléculas de adesão célula-matriz; 5) superprodução de metaloproteinases (FIGUEIREDO et al., 2003).

Como descrito anteriormente, muitos são os fatores que influenciam o aparecimento, crescimento, invasão e metástases nos tumores. Estes fatores podem ter várias origens, podendo estar associados a alterações em determinadas regiões genômicas, por exemplo, bem como a antígenos, interação entre células e vascularização. 
A radiação solar ultravioleta (UV) é considerada como um importante fator etiológico do câncer de pele melanoma e não-melanoma, sendo que evidências indicam que o estresse oxidativo nas células, gerado pela exposição a radiação UV, está envolvido na fotocarcinogênese. Espécies reativas de oxigênio participam de inúmeros processos patofisiológicos, incluindo danos no DNA e peroxidação lipídica (LPO) e são considerados como sendo um fator determinante na progressão tumoral (MARITIM et al, 2003).

A radiação ultravioleta também pode reagir com os precursores da melanina, sendo esta reação mais intensa com o precursor feomelanina (encontrado nas células de pessoas ruivas ou loiras) do que com a eumelanina, precursora da melanina em peles negras (PREMI, et al, 2015). Isso explica o fato de que em países tropicais, onde há alta incidência de sol, populações com uma grande pigmentação produzem o precursor eumelanina e raramente desenvolvem cânceres de pele (melanoma ou não) ao passo que as pessoas de pele clara que, produzem feomelanina, vivendo em países onde há alta ou baixa incidência de sol, são mais suscetíveis ao câncer de pele, melanoma ou não (PREMI, et al, 2015).

\subsection{Os tratamentos para o melanoma}

O tratamento adequado e eficaz e o diagnóstico correto são essenciais visto que para cada tipo de melanoma, é nescessário um tratamento específico, que pode incluir um ou mais métodos. O tratamento padrão é a remoção cirúrgica do melanoma primário, seguido ou não, da quimioterapia, ou radioterapia ou ainda imunoterapia (HOU et al, 2015). A escolha das modalidades terapêuticas usadas depende principalmente do estágio do câncer. Por exemplo, quando há metástase, o local do tumor e outros fatores, como estado geral de saúde do paciente também são considerados (PULIDO, 2007).

O melanoma em estágio 0 ou melanoma in situ invade apenas a camada mais externa da pele e geralmente é removido cirurgicamente para remover a lesão ou o nevu. O mesmo é feito para o melanoma no estágio 1 e 2 , aqueles em que a lesão tem até $1 \mathrm{~mm}$ (estágio 1) ou mais de $1 \mathrm{~mm}$ (estágio 2) mas não se espalhou para 
os nódulos linfáticos. Quando o melanoma está no estágio 0 ou 1, os problemas estéticos e emocionais ao paciente não são tão severos. Sendo que para os estágios 0,1 e 2, o tratamento além de cirúrgico, também utiliza a quimioterapia com ou sem radioterapia. Porém, melanoma no estágio 2 ou 3, muitas vezes, requer uma segunda ou concomitante cirurgia reconstrutora, principalmente no rosto e nas mãos. O melanoma em estágio 3 , em que a doença se espalhou para os nódulos linfáticos, o tratamento inclui cirurgia para remoção do melanoma primário e de todos os nódulos linfáticos próximos e imunoterapia.

No melanoma estágio 4, a doença se espalhou para além da área inicial do câncer e os nódulos linfáticos próximos, talvez para o fígado, o cérebro ou os ossos. O tratamento pode incluir cirurgia, radioterapia, quimioterapia, ou imunoterapia. A intervenção cirúrgica pode acontecer não só no local da lesão inicial (melanoma primário), mas também para a retirada de linfonodos (nódulos linfáticos) sentinelas e lesões em outros órgãos.

Nódulos linfáticos inchados ou sensíveis podem ser um sinal de que o melanoma se espalhou. Qualquer nódulo linfático inchado deve ser removido e examinado. Quando ocorre o estágio 4 (metastático) há uma dificuldade no sucesso do tratamento devido ao elevado grau de comprometimento de outros tecidos. De um modo geral, o objetivo do tratamento neste estágio é controlar os sintomas, reduzir as complicações e aumentar o conforto (tratamento paliativo), não indicando que há a intenção de cura da doença (DEUTSCH et al, 2015).

O sistema descrito por Breslow e Clark ajudam a classificar a invasividade do tumor pela medição da profundidade das células tumorais dadas em milímetros por exames histopatológicos e correlaciona com o nível anatômico de invasão no tecido, porém apesar de oferecer mais informação, o sistemaa descrito pode tornarse complicado já qu pode não ter reprodutibilidade. A probabilidade de não haver reprodutibilidade é dada pelos diferentes tipos de melanoma, com ou sem a presença de malenina e da variedade dos tecidos afetados (BARNHILL \& LEVY, 1993). Segundo o sistema descrito por Clark (GON et al., 2001), a classificação dos níveis de invasão da melanima são: nível-I, crescimento intra-epidérmico; nível-II, invasão da derme papilar; nível-III, atinge o limite entre a derme papilar e reticular; 
nível-IV, invasão da derme reticular e nível-V, invasão subcutânea. Essas informações são importantes uma vez que o tratamento quimioterápico ou cirúrgico é basaedo nas informações geradas pelos sistemas de Breslow e Clark.

No caso do tratamento quimioterápico, este utiliza drogas citotóxicas de modo a eliminar as células neoplásicas, esses medicamentos podem ser administrados sozinhos ou em combinação com outras drogas. Nesse caso a(s) droga(s) é administrada por via endovenosa, em ciclos, com cada período de tratamento seguido por um período de descanso. Cada ciclo de quimioterapia dura em geral de 2 a 3 semanas. Mesmo reduzindo o tamanho dos tumores, o efeito da quimioterapia, muitas vezes, é apenas temporário, em média três a seis meses antes da doença voltar a progredir. No caso de recidiva ela ocorre na própria cicatriz da cirurgia ou próximo ao tumor original. Em geral, as recidivas locais são tratadas com uma cirurgia similar a que se recomenda para o melanoma primário (VAN BEEK et al, 2015).

Dentre as principais drogas citotóxicas utilizadas no tratamento do melanoma está a Dacarbazina e a Temozolida, que muitas vezes são utilizados em combinação com Carmustina, Cisplatina, Vimblastina ou Tamoxifeno. (PEER et al., 2007). Esta terapêutica continue tendo imensas desvantagens, pois os agentes quimioterapêuticos convencionais são bastante inespecíficos, com uma elevada toxicidade e resultando numa dose subterapêutica (devido à baixa acumulação tumoral). A quimioterapia também pode ser utilizada em combinação com a imunoterapia (GOYDOS et al, 2006).

O tratamento radioterápico do melanoma utiliza radiações ionizantes para destruir células tumorais que tenham permanecido após excisão da lesão, para reduzir a chance de uma recidiva. No entanto, a radioterapia é pouco utilizada para o tratamento de melanoma (GOYDOS et al, 2006).

O tratamento do câncer que promove a estimulação do sistema iminológico, por meio do uso de substâncias modificadoras da resposta biológica, é denominado imunoterapia.

Há muito tempo se conhece a relação entre competência imunológica e evolução da doença malígna, especialmente a redução da atividade das células 
supressoras tem sido demonstrado em pacientes com câncer de ovário, neuroblastoma e carcinoma hepatocelular. A produção de anticorpos está relacionada com os linfócitos $B$, enquanto a imunidade mediada por células se relaciona com os linfócitos $T$. Os monócitos e os macrófagos também são células do sistema imune e facilitam a atividade dos linfócitos $T$ e de modificadores da resposta biológica, como as interleucinas. Mais de setenta atividades biológicas diferentes são mediadas por produtos de linfócitos, monócitos e macrófagos. Esses mediadores podem ser classificados como fatores auxiliares, supressores, reguladores do crescimento e citotóxicos (SCHMERLING \& BUZAID, 2013).

A imunoterapia é classificada em ativa e passiva, de acordo com as substâncias utilizadas e seus mecanismos de ação. Na imunoterapia ativa, substâncias estimulantes e restauradoras da função imunológica (imunidade inespecífica) e as vacinas de células tumorais (imunoterapia específica) são administradas com a finalidade de aumentar a resistência ao crescimento tumoral. As vacinas e soros são produzidos a partir de culturas de células tumorais coletadas do próprio paciente ou de outro paciente com neoplasia semelhante.

$\mathrm{Na}$ imunoterapia passiva ou adotiva, anticorpos antitumorais ou células mononucleares são administrados com o objetivo de proporcionar o aumento da capacidade imunológica. $\mathrm{Na}$ imunoterapia passiva são uilizados agentes imunomoduladores como: a) anticorpos monoclonais, tais como o Ipilimumab, um anticorpo anti-proteína 4 de linfócitos T citotóxicos (CTLA4) ou o Bevacibumab, um anticorpo anti-fator de crescimento endotelial vascular (VEGF); b) citocinas, como a interleucina-2 e o inteferon recombinantes; c) inibidores de transdução de sinal, como os inibidores de braf (Dabrafenib, Ipilimumabe) e de MEK (Trametinibe, Vemurafenibe, Trametinibe); ou d) terapia baseada nas vacinas (GOYDOS et al, 2006), (GARBE et al, 2015), (Cancer Research UK, 2015), (National Cancer Institut, 2015).

Cerca da metade dos casos de câncer de pele melanoma têm mutações no gene braf. Estas alterações fazem com que as células do melanoma cresçam e se dividam rapidamente. Os medicamentos Dabrafenib e Ipilimumabe provocam a 
diminuição do tamanho dos tumores em cerca da metade dos pacientes cujo melanoma metastático tem a alteração no gene braf.

Estes medicamentos são administrados via oral, duas vezes ao dia. Os efeitos adversos mais comuns são dor nas articulações, fadiga, perda de cabelo, erupção cutânea, prurido, sensibilidade ao sol e náuseas, problemas cardíacos, hepáticos, oculares e na pele, além deinsuficiência renal, reações alérgicas e aumento dos níveis de açúcar no sangue.

O gene mek está na mesma via de sinalização que o gene braf, de modo que os medicamentos que bloqueiam a proteína MEK também ajudam no tratamento de melanomas com alterações no gene braf. Os medicamento que bloqueiam a proteína MEK e os inibidores de transdução de sinal, como os inibidores de braf, quando usados isoladamente, ã parecem não reduzir muitos melanomas como os inibidores de BRAF, embora ainda possa ajudar alguns pacientes. Outra abordagem é combiná-lo com um inibidor de BRAF, na esperança de reduzir os tumores por maior período de tempo.

Nesse contexto, o interferon (proteína produzida pelo sistema imunológico em resposta à ameaça de agentes como vírus, bactérias, parasitas e tumores) e a interleucina-2 (proteína do sistema imunológico envolvida na ativação dos linfócitos e na indução da proliferação de células específicas de defesa) têm sido mais amplamente utilizados na imunoterapia do melanoma, porém ainda está sendo alvo de intensa pesquisa. Essas terapias causam muitos efeitos colaterais, como fadiga, sintomas constitucionais, cefaleia, náuseas, perda de peso, mielosupressão e depressão. Todavia, apesar dos primeiros resultados promissores obtidos até 0 momento, não foi demonstrado nenhum benefício claro em termos de sobrevida, e as críticas ao seu uso estão relacionadas ao fato de ser um tratamento tóxico e sem evidências de vantagem consistente na sobrevida a longo prazo (PULIDO, 2007; DERMATOLOGIA de FITZPATRICK, 2011).

Embora a taxa de sobrevida seja maior do que $90 \%$ quando o melanoma é detectado precocemente, esta diminui para $60 \%$ em formas mais avançadas como melanoma estágio 2 , para $10 \%$ em melanoma estágio 3 , ou até para completa 
fatalidade em casos de melanoma estágio 4. Isso se deva à falta de tratamentos avançados para melanomas (MUELLER, 2009).

Apesar de apresentar bons resultados, esses tratamentos, principalmente, a quimioterapia e a radioterapia, não são específicos para as células tumorais e, devido a isso, culminam em um resultado terapêutico não satisfatório, sem erradicação completa das células malignas, além de induzirem efeitos adversos severos (SIBAUD , 2015).

Nesse sentido, novas modalidades de tratamento vêm sendo projetadas e desenvolvidas utilizando produtos e processos tecnológicos a partir de materiais organizados na escala de nanômetros. A ciência que estuda esses materiais é denominada de nanociência e a sua aplicação de nanotecnologia.

\subsection{A nanotecnologia}

Segundo o relatório 229 do comitê técnico da Organização Internacional de Padronização ISO TC (INTERNATIONAL, 2005) a nanotecnologia é: "entendimento e controle de matérias e processos em escala nanométrica, tipicamente, mas não exclusivamente, abaixo de 100 nanômetros, em uma ou mais dimensões onde o surgimento de fenômenos dependentes do tamanho usualmente propicia novas aplicações"; além de "utilização das propriedades de materiais em escala nanométrica que diferem das propriedades dos átomos individuais, moléculas e matéria (bulk matter) para criar melhores materiais, dispositivos e sistemas que explorem estas novas propriedades".

Os nanomateriais apresentam grande área de superfície em relação à massa, permitindo alta capacidade de funcionalização, e são amplamente aplicados em diferentes setores (MODY et al, 2010; FALLEIROS et al, 2011; BRAKMANE et al, 2012). Na biomedicina o emprego destes materiais levou ao desenvolvimento da nanomedicina, tendo tido um grande impacto no crescimento de novos e/ou melhores procedimentos de diagnóstico e/ou terapia.

Nanomateriais utilizados como veículos de entrega de drogas (nanovetores) representam uma das aplicações mais promissoras da nanomedicina (WANG \& THANOU, 2010). Os nanovetores quando funcionalizados podem promover a 
entrega do agente terapêutico a um tecido/sítio específico, diminuindo os efeitos adversos, principalmente aqueles associados a altas doses de fármacos utilizadas em tratamentos convencionais (LIU et al, 2011). Assim, estes nanosistemas podem promover a redução da dose de medicamento administrada, e ao mesmo tempo maximizar o seu efeito no local desejado, evitando o contato e dano dos tecidos sadios (SURENDIRAN et al, 2009; GMEINER \& GHOSH, 2014).

A Nanotecnologia surge então como uma opção de tratamento para diversas patogenias, com perspectiva promissora para o melhoramento de terapias oncológicas existentes, pois permite a modificação e optimização das propriedades físicas, químicas e biológicas das partículas e, portanto, tem uma aplicação vasta nas áreas da Medicina, Farmacologia, Electrônica, Química, etc. (OCHEKPE, et al., 2009).

Atualmente as modalidades tecnológicas mais empregadas na nanovetorização de agentes terapêuticos contra o câncer, são: lipossomas, micelas, dendrímeros, nanopartículas poliméricas, nanoemulsões, nanotubos de carbono e nanopartículas superparamagnéticas (ZACARIA et al, 2015). Neste trabalho foram utilizadas micelas poliméricas, que estão descritas no item 1.9.

Assim, o emprego da nanotecnologia como ferramenta para a elaboração de veículos de entrega de drogas associado a modalidades terapeuticas antineoplásicas vem sendo cada vez mais explorada, principalmente na terapia fotodinâmica.

\subsection{A terapia fotodinâmica}

A Terapia Fotodinâmica, TFD, é uma modalidade terapêutica promissora para o tratamento do câncer, que oferece a possibilidade de remissão ou mesmo ação paliativa em certos casos de câncer, como o câncer de pele, pulmão e bexiga. É clinicamente aprovada por ser uma terapia não-invasiva e assim vem sendo amplamente utilizada tanto na área de dermatologia quanto na de odontologia, para tratar lesões cutâneas e orais, infecções, doenças cardiovasculares e oftalmológicas, 
entre outras (LEVY et al., 1996; DOUGHERTY et al., 2002; FAYTER et al., 2010; PORTILHO et al, 2013).

Atualmente, a TFD tem se mostrado eficaz no tratamento de diversos tipos de neoplasias, como de bexiga, pulmão, cabeça e pescoço, esôfago e nos casos de esôfago de Barrett, doença de Bowen (JONES et al., 1992) carcinoma de células escamosas (WILSON et al., 1992), carcinoma de seio recorrente e metastático MCCAUGHAN et al., 1989) e sarcoma de Kaposi (SCHWEITZER \& VISSCHER, 1990). Além disso, a TFD vem sendo considerada o tratamento ideal para o câncer de pele (SCHUITMAKER et al., 1996; TRIESSCHEIJN et al., 2006; CHATTERJEE, FONG \& ZHANG, 2008).

São três componentes principais nesta terapia: 1- fotossensibilizante, 2- luz e 3- oxigênio molecular.O princípio da TFD está na geração de espécies reativas, em que o fotossensibilizante, quando ativado por uma luz de comprimento de onda específico; e na presença de oxigênio molecular, forma as espécies reativas que reagem com biomoléculas, ou forma o oxigênio singleto reativo, e assim são capazes de induzir a morte celular, seja por mecanismos apoptóticos ou necróticos (JORIS et al, 2013; HUANG et al, 2006, CZERSKA et al, 2015).

As reações que ocorrem na terapia fotodinâmica iniciam quando um fármaco fotossensível, denominado de fotossensibilizante (FS) é introduzido nas células-alvo seguido da irradiação com luz em comprimentos de onda na faixa de 600 a $900 \mathrm{~nm}$. Quando isso acontece, conforme ilustrado na Figura 5, o FS, que se encontra no estado fundamental $\left(S_{0}\right)$ passa para um estado singleto excitado $\left(S_{1}\right)$, um estado energético maior e de vida mais curta. Nesse estado $S_{1}$, o FS pode voltar ao estado fundamental ou passar rapidamente para o estado tripleto $\left(T_{1}\right)$ devido a mudanças intersistemas (ISC). O FS em seu estado $\mathrm{T}_{1}$ pode reagir com $\mathrm{O}_{2}$ por dois mecanismos fotoquímicos distintos. O mecanismo denominado de reação do Tipo I, envolve a transferência direta de prótons do FS para substratos celulares orgânicos (lipídios, proteínas, ácidos nucleicos, etc.) formando radicais livres ou íons radicais que interagem com o oxigênio molecular para produzir espécies reativas de oxigênio (ERO), como peróxido de hidrogênio $\left(\mathrm{H}_{2} \mathrm{O}_{2}\right)$, ânion superóxido $\left(\mathrm{O}_{2}\right)$ e radical 
hidroxil $\left(\mathrm{OH}^{-}\right)$. A reação tipo II envolve a transferência de energia do FS no estado $T_{1}$ para $\mathrm{O}^{3} \mathrm{O}_{2}$, no estado fundamental, formando oxigênio singleto altamente reativo ${ }^{1} \mathrm{O}_{2}$. Ambos os tipos de reação causam oxidação de várias moléculas celulares e podem induzir a morte celular via apoptose, necrose ou autofagia. $\mathrm{O}^{1} \mathrm{O}_{2}$ produzido na reação do tipo II é provavelmente o responsável pela morte celular induzida na TFD (LIM, 2012). Por outro lado, os radicais podem, indiretamente, estimular a transcrição que induz a proliferação celular (DING et al, 2011).

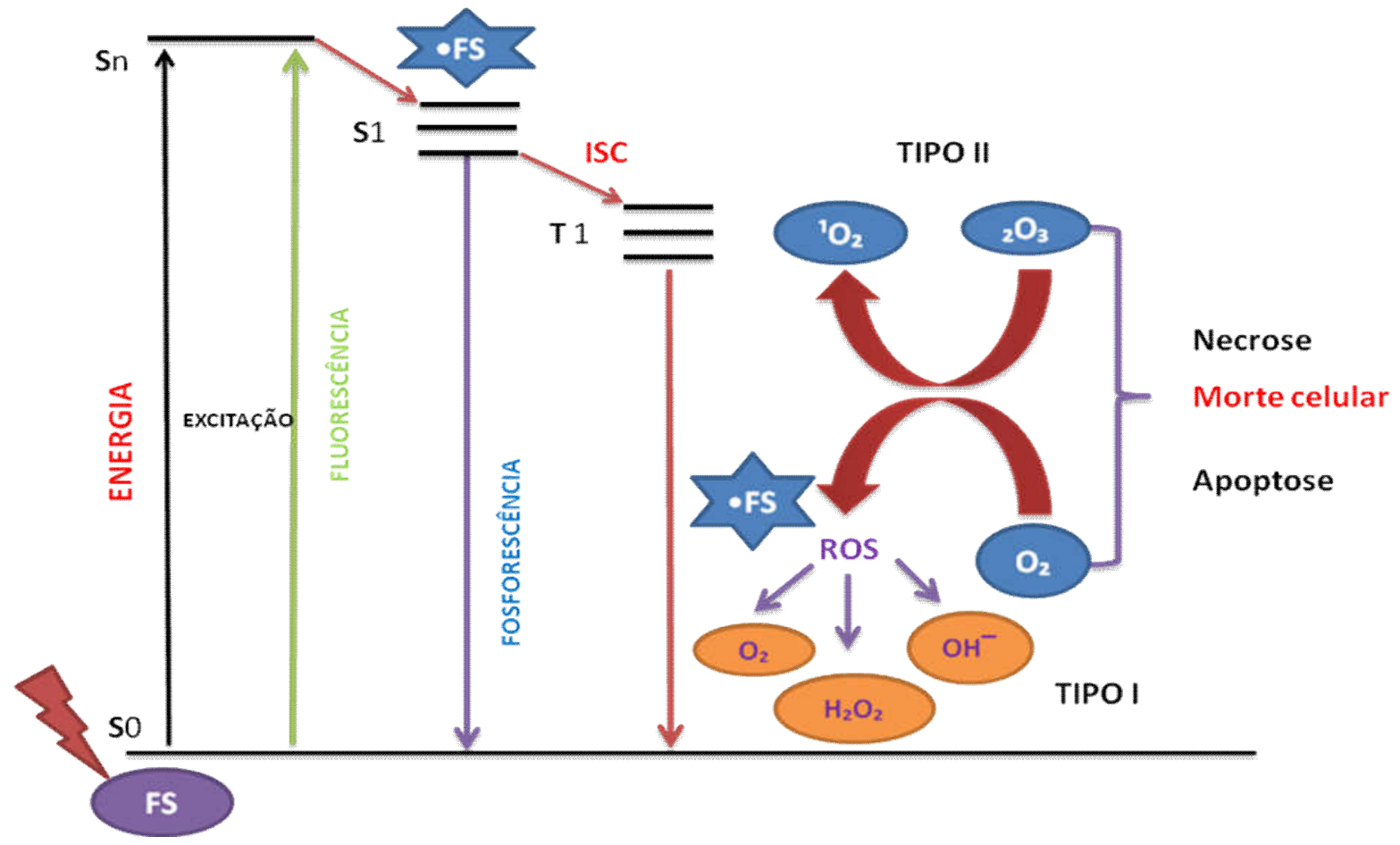

Figura 05. Diagrama dos níveis de energia de Jablonski para a terapia fotodinâmica (TFD). O fotossensibilizante (FS) após a radiação da luz muda do estado fundamental $\left(S_{0}\right)$ para o singleto $\left(S_{1}\right)$ e, por meio de mudanças intersistema (ISC) rapidamente encontra-se no estado tripleto $\left(T_{1}\right)$. Neste estado $T_{1}$, o $\mathrm{FS}$ na presença do $\mathrm{O}_{2}$ pode produzir espécies reativas de oxigênio (ERO) pela reação do tipo I e/ou produzir oxigênio singleto altamente reativo $\left({ }^{1} \mathrm{O}_{2}\right)$ pela reação do tipo II, ambos causando a morte celular por necrose ou apoptose (Adaptado de MAJUMDAR et al, 2012). 
Além disso, a TFD tem outro mecanismo capaz de matar o tumor, que é o seu efeito na vascularizaçãso, o qual varia de acordo com o FS utilizado. A aplicação da TFD com ftalocianinas causa principalmente o aumento da permeabilidade vascular, enquanto a TFD com mono-L-aspartilclorina e6 (MACE) resulta na estase do fluxo sanguíneo e agregação de plaquetas (MCMAHON et al., 1994). Por outro lado, a vasoconstrição via inibição da produção ou liberação de óxido nítrico pelo endotélio vascular, também é um efeito causado pela Terapia Fotodinâmica (GILISSEN et al., 1993).Nesses casos, o mecanismo vascular priva o tecido tumoral de oxigênio e nutrientes necessários ao seu crescimento.

Finalmente, a TFD pode causar alterações nas membranas citoplasmáticas e de organelas e induzir uma rápida ativação de fosfolipases de membrana levando a uma acelerada degradação de fosfolipidios e uma maciça liberação de mediadores inflamatórios (YAMAMOTO et al.,1992). A sinalização inflamatória após a TFD desencadeia uma invasão regulada de neutrofilos, mastócitos e monócitos/macrófagos, estimulando o sistema imune, principalmente os leucócitos, a reconhecer e destruir células tumorais localizadas no local da inflamação ou em outros locais adjacentes.

Estudos de substâncias fotossensíveis, com efeito citostático ou citotóxico, são relatados deste o início do século XX (FINSEN, 1903; MEYER-BETZ, 1913) e desde então é crescente a pesquisa para o desenvolvimento de fotossensibilizantes que apresentem uma maior eficácia terapêutica (MACDONALD \& DOUGHERTY, 2001).

\subsection{Os fotossensibilizantes}

Os primeiros fotossensibilizantes (FS), denominados de primeira geração, utilizados na TFD eram à base de porfirinas, que embora tenham representado um progresso terapêutico apresentam algumas desvantagens como a pequena absorção na região da janela terapêutica (660-700 nm) e a excreção lenta pelo organismo, resultando em uma prolongada fotossensibilidade da pele, e assim exigindo que o paciente permaneça ao abrigo do sol por vários dias (CARINA SILVA DE PAULA, 2008). 
Em vista disto, outros fotossensibilizantes foram desenvolvidos, os denominados FS de segunda geração, sendo os principais representantes dessa classe as ftalocianinas. Esses FS de segunda geração possuem altos coeficientes de absorção e geração de energia, penetram profundamente em tecidos biológicos, pois absorvem luz na faixa de 650-850 nm, além de serem excretados mais rapidamente do que os FS de $1^{a}$ geração. Desta forma, não são tóxicos na ausência de luz (CALZAVARA-PINTON, 2007). Entretanto, a maioria deles é hidrofóbico, o que dificulta a sua aplicação em organismos.

Para solucionar o fato da hidrofobicidade dos fotossensibilizantes de $2^{\mathrm{a}}$ geração, uma solução dada pela Nanotecnologia foi a de associá-los a carreadores nanoestruturados, como lipossomos, nanopartículas sólidas, micelas, nanoemulsões ou conjugá-los a compostos como anticorpos, peptídeos e ácido fólico e assim ser uma ferramenta importante e com resultados promissores na aplicação da TFD. (YANO et al, 2011) Estes novos sistemas de fotossensibilizantes são denominados de $3^{\mathrm{a}}$ geração.

LONGO e colaboradores (2009) analisaram a eficiência da ftalocianina associada a lipossomos como mediador da TFD contra tumores de Ehrlich induzidos na língua de camundongos Swiss. Este estudo mostrou que o tratamento ocasionou necrose em $90 \%$ dos tumores e a eliminação da vascularização do tumor após a TFD mediada pelo lipossoma-ftalocianina, porém quando usada a ftalocianina na forma livre, não foi obtido mesmo sucesso.

\subsection{Alumínio-Cloro-Ftalocianina}

As ftalocianinas são uma classe de FS que vem atraindo bastante atenção devida as suas propriedades fotoquímicas e fotofísicas e, portanto, tem apresentado bons resultados na área de TFD. Um alto coeficiente de absorção espectral na faixa de comprimentos de onda longos, entre $650-850 \mathrm{~nm}$, o que corresponde ao intervalo da região do vermelho visível, e o alto poder de penetração são vantagens deste derivado de azoporfirina. As ftalocianinas possuem uma alta eficiência devido ao seu alto rendimento quântico e são rapidamente captadas pelo sistema retículoendotelial, facilitando a eliminação, e ao mesmo tempo apresentam longo tempo de 
retenção em células neoplásicas (ALLISON et al, 2004; DETTY et al, 2004; WAINWRIGHT, 2008; O'CONNOR, 2009; BONETT, 2010).

As ftalocianinas são capazes de se ligar a uma variedade de espécies metálicas, principalmente alumínio e zinco (MARTINS et al, 2004; KOLAROVA et al, 2007a; KOLAROVA et al, 2007b), a presença e a natureza do íon metálico central elevada capacidade de geração e a um aumento na durabilidade do estado tripleto eletrônico, essencial para a eficiência das reações fotoquímicas (MAFTOUM-COSTA et al, 2008; DURMUS \& AHSEN, 2010). Nesse sentido, estudos têm apontado o complexo Alumínio-Cloro-Ftalocinina (AICIPC), na figura 6, como um dos mais favoráveis para a aplicação na TFD (MAFTOUM-COSTA et al, 2008).

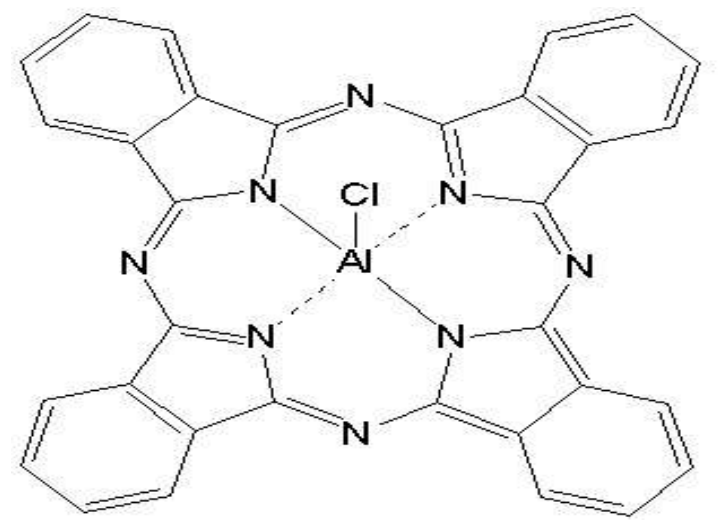

Figura 06. Estrutura quimica da cloro-aluminio ftalocianina. Adaptada de MAFTOUM-COSTA, 2008.

No entanto, o caráter hidrofóbico das ftalocianinas causa sua baixa solubilidade em meios hidrofílicos, como os sistemas biológicos, e aumenta muito a sua agregação, reduzindo sua capacidade fotoativa. Portanto, o uso de nanovetores para transportar este FS surge como alternativa importante. Essa estratégia permite a manutenção da forma monomérica do FS em meios hidrofílicos e aumento no controle da seletividade, uma vez que alterações na composição dos nanovetores, como a adição de grupos funcionais, podem ser feitos de forma a adequá-los para o 
transporte e direcionamento às células e tecidos-alvo em meio fisiológico (FERRARI, 2011; WANG \& THANOU, 2010).

\subsection{Micelas de Pluronic ${ }^{\circledR}$ F127}

Com o desenvolvimento da nanobiotecnologia, o número de materiais nanométricos utilizados para o transporte e liberação controlada de fármacos no tratamento de várias doenças vem se tornando cada vez maior. Estes nanocarreadores podem remediar deficiências como, biodistribuição incorreta da droga (baixa especificidade), baixa estabilidade e solubilidade dos fármacos. Os nanocarreadores oferecem vantagens, como a possibilidade de ter o seu uso controlado externamente (com marcações bioluminescentes) e o emprego como agentes teranósticos. Esse termo surgiu para definir materiais que combinam funcionalidades de agentes de contraste e terapêuticos concomitantemente (MONGE-FUENTES et al, 2009).

Vale lembrar que a vetorização de fármacos deve romper barreiras biológicas específicas e, em seguida, liberar o fármaco no local desejado (SANTA \& OSÓRIO, 2013). Além disso, sabe-se que o efeito EPR (do inglês Enhanced Permeability and Retention) (em contraste com tecidos e órgãos normais, a maioria dos tumores sólidos mostram uma densidade vascular superior, isto é, a angiogênese em tumores sustenta o seu crescimento) também é uma característica importante na eficiência terapêutica dos nanocarreadores no tratamento de tumores (FAROKHZAD \& LANGER, 2009).

Dentre os materiais mais promissores para a obtenção de nanocarreadores, estão os polímeros, em parte graças à grande variedade e versatilidade destas moléculas e também a fácil modulação de suas propriedades físico-químicas de síntese, tornando-os biocompatíveis e biodegradáveis e, portanto, excelentes candidatos como matéria-prima na produção dos nanocarreadores (GIL \& HUDSON, 2004).

Dentre os nanocarreadores utilizados na nanomedicina estão liposomas, dendrímeros, nanoemulsões, nanopartículas lipídicas sólidas (LPS) e micelas 
(esférica, reversas, cilíndricas e tipo vermiculares) formadas em conjuntos de lamelas, estruturas bicontínuas ou vesículas (Figura 07).

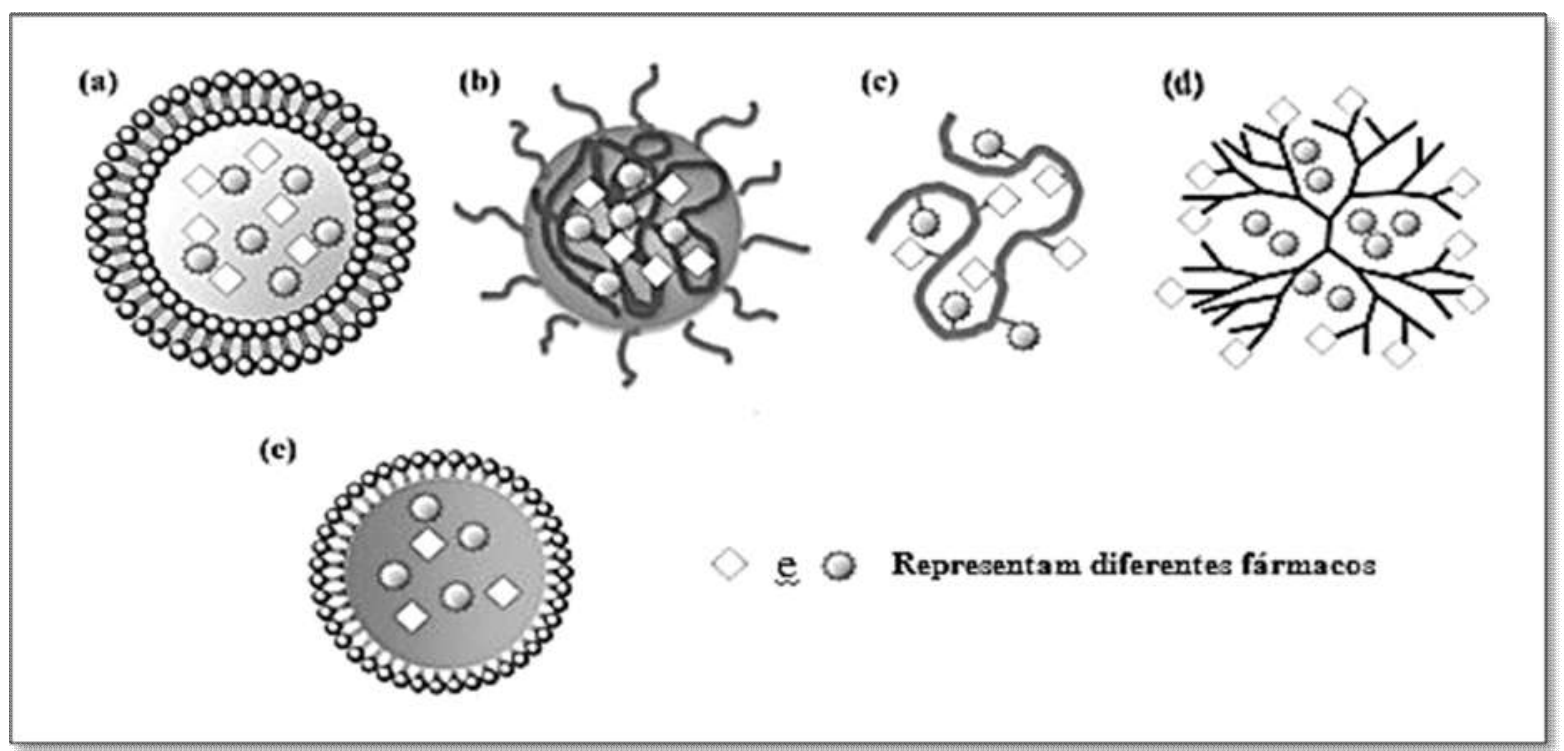

Fgura 07. Diferentes vetores usados em nanomedicina aplicada ao transporte de fármacos, sendo alguns já utilizados em terapia clínica e pré-clínica: a) liposomas; b) micela polimérica; c) conjugado unímeros-fármaco; d) dendrímeros; e) nanoemulsão ou LPS (retirado e adaptado de: HU, et al. 2012).

As micelas poliméricas foram primeiro propostas como transportadores de fármacos por RINGSDORF em 1984 (BADER et al., 1984) que foram emergindo como um sistema de transporte conveniente. Alguns artigos recentemente publicados proporcionaram excelentes comentários sobre o uso de micelas poliméricas como transportadores de drogas em geral (JHAVERI \& TORCHILIN, 2014; GEMMA et al., 2015).

Uma vez que muitos fotossensibilizantes normalmente apresentam alguma toxicidade contra células e tecidos saudáveis, portadores são preferencialmente obrigados a entregá-los no sítio patogênico por segmentação passiva ou ativa (VROUENRAETS et al., 2003) e por muitos fotossensibilizadores serem insolúveis 
em água, micelas poliméricas são úteis tanto para solubilização quanto como veículo de entrega.

As micelas são conjuntos dinâmicos compostos por um núcleo líquido ou sólido hidrofóbico e revestido com cadeias hidrófilas, portanto, permitem a solubilização de princípios ativos hidrófobos no seu centro líquido. Possuem tamanhos entre 10 e 100 nm (BENÍTEZ et al, 2012).

Dentre os polímeros que formam as micelas, os copolímeros em blocos (incluindo dendrímeros bloco e enxerto) são notáveis por sua capacidade de automontagem em meios aquosos e assim formar diferentes tipos de conjuntos de lamelas, estruturas bicontínuas ou vesículas esféricas. As micelas em vesículas esféricas preparadas com copolímeros de bloco são conjuntos com um núcleo micelar hidrofóbico, normalmente onde se encontra o ingrediente ativo, adsorvido ou encapsulado devido às ligações com a porção hidrofóbica do copolímero, que está voltada para este núcleo. A porção hidrofílica do copolímero permanece voltada para a superfície externa, formando o bloco estrutural da micela (TORCHILIN, et al, 2001).

As micelas têm uma vantagem em comparação com outros tipos de nanocarreadores porque permite transportar drogas hidrófilas e hidrofóbicas simultaneamente, o que é útil no desenvolvimento de terapias múltiplas. São amplamente utilizados não só na área da medicina, mas em toda a área da química coloidal por causa de suas propriedades tensoativas (BENÍTEZ et al, 2012). Para a vetorização de fármacos hidrofóbicos anti-tumorais, as micelas são excelentes candidatas, pois devido ao seu pequeno tamanho e a seu maior efeito EPR, são capazes de fornecer drogas à tumores pouco permeáveis, tais como os tumores sólidos (TORCHILIN, et al, 2001).

Dentre os copolímeros em bloco usados na preparação de micelas em vesículas esféricas está o Pluronic ${ }^{\circledR} \mathrm{F} 127$, também conhecido como poloxamero, é constituído de óxido de etileno (EO) e óxido de propileno (PO) formando uma estrutura em tri-bloco na base A-B-A, ou seja, $\mathrm{PEO}_{2}-\mathrm{PPO}_{3}-\mathrm{PEO}_{2}$. Na síntese desta micela, monômeros hidrofóbicos de $\mathrm{PO}$ ao polimerizar forma um bloco e em suas 
extremidades, há a adição de monômeros hidrofílicos de EO. Sendo que este balanço hidrofílico e hidrofóbico, ou seja, a quantidade de cada tipo de monômero, pode variar de acordo com a aplicação biológica proposta. A Figura 08 mostra como é a estrutura de uma micela formada pelo copolímero em blocos de Pluronic ${ }^{\circledR}$-F127. KABANOV et al., 2002 relata que o Pluronic ${ }^{\circledR}$ tem sido frequentemente usado como um agente de solubilização em formulações de drogas (KABANOV et al., 2002).

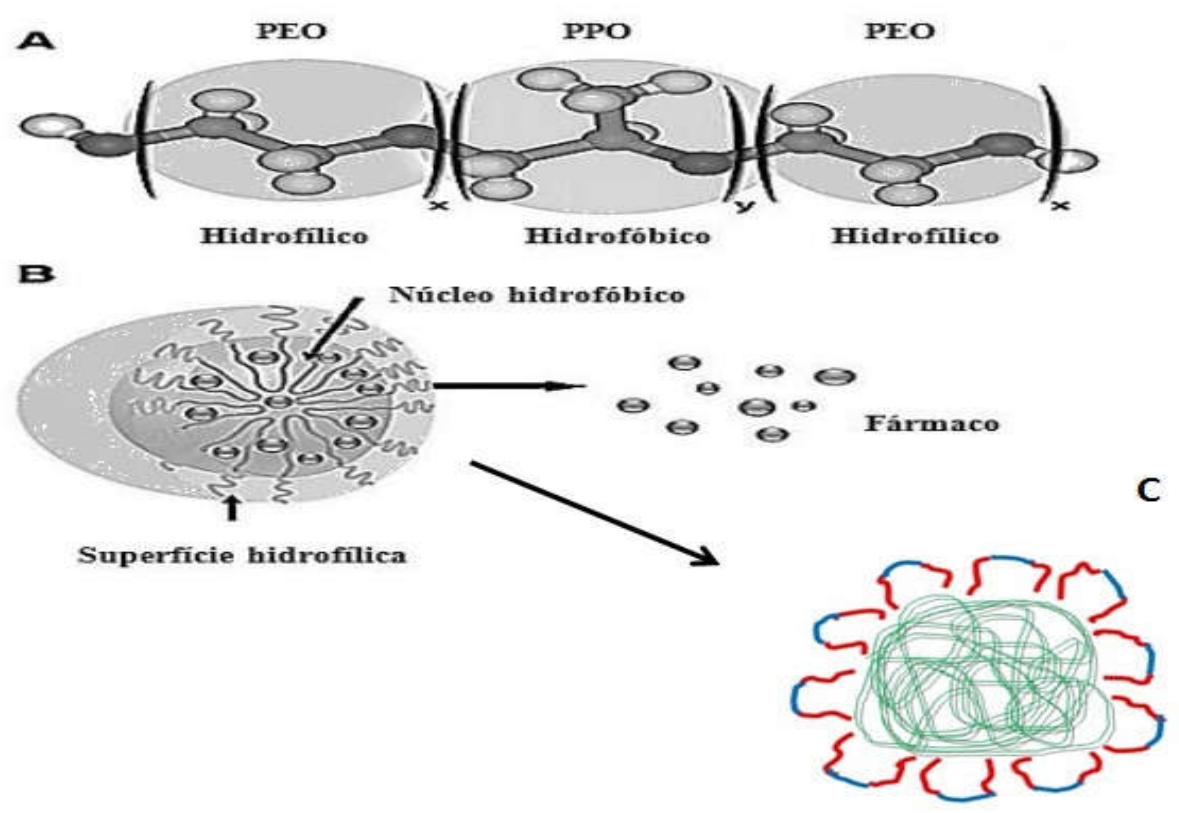

Figura 08. Representação de micelas de copolímeros em bloco de Pluronic ${ }^{\circledR}$ F127. A- representa a estrutura química em tri-bloco (A-B-A) do copolímero Pluronic ${ }^{\circledR}$ F127, com os monômeros de óxido de etileno (EO) e óxido de polietileno (PO). BAspecto das micelas com o núcleo micelar em amarelo e o revestimento de cadeia hidrofílica em azul e vermelho. C- Detalhe da organização da micela NP F127/AICIPc, contendo o agente hidrofóbico no centro (em verde) e a disposição do Pluronic $^{\circledR} \mathrm{F} 127$, com seu blocos hidrofóbicos (vermelho) voltado para o núcleo micelar e a cadeia hidrofílica (azul) formando o bloco estrutural externo da micela. Adaptado de BASAK \& BANDYOPADHYAY, 2013. 
Micelas de copolímeros em bloco Pluronic ${ }^{\circledR}$ são altamente interessantes, devido à sua natureza não iônica e não tóxica, flexibilidade para utilização em formulações farmacêuticas diferentes e boa seletividade contra células resistentes a múltiplas drogas (MDR- do inglês MultiDrug Resistance) inibindo as bombas que expulsam os quimioterápicos do interior da célula (CHEN et al, 2009, YEE et al, 2012), assim como aprimorando a sinalização pró-apoptótica (ALAKHOV \& KABANOV, 2002). Quando os polímeros são colocados num solvente orgânico, ocorre a micelização destas nanopartículas de forma espontânea, sendo a síntese bastante simples, barata e rápida, comparativamente a outros tipos de nanopartículas (LETCHFORD et al. 2007). Além disso, a sua capacidade de prolongar o tempo de circulação dos fármacos tem atraído a atenção para a investigação de seu uso como sistemas de fornecimento de vários tipos de drogas (BATRAKOVA \& KABANOV, 2008), por exemplo, quando doxorrubicina é administrada em combinação com Pluronic $^{\circledR}$ observa-se uma citotoxicidade potencializada (BATRAKOVA et al, 2001).

O Pluronic ${ }^{\circledR}$ em solução aquosa (ou em um solvente seletivo para apenas uma das porções) tende a se concentrar nas interfaces do sistema por adsorção, pois minimizam as interações desfavoráveis e/ou maximizam as interações favoráveis, visando reduzir a energia livre do sistema onde se encontram. De uma forma simples, a formação desses agregados moleculares ou micelas estáveis em solução aquosa é impulsionada pela hidrofobicidade das porções apolares de suas moléculas, e pela hidrofilicidade das porções polares. Dessa maneira, em solução aquosa, essas moléculas se agregam de formas variadas (esféricas, cilíndricas, lamelares e em disco; (MYERS, 1992) com sua porção hidrofóbica constituindo a parte interna (núcleo) e a porção hidrofílica, a parte externa (coroa). Vale a pena ressaltar que todo polímero, independentemente da sua forma, tem uma concentração micelar crítica (CMC) e uma temperatura crítica micelar (CMT).

A CMC é a menor concentração de um surfactante onde ocorre a formação de micelas (micelização), a qual é uma propriedade intrínseca e característica do surfactante. A CMT é a temperatura a partir da qual, numa dada concentração, as moléculas começam a se agregar em micelas. (GARREC et al. 2004). A CMC de um 
surfactante é um de seus parâmetros mais importantes, uma vez que muitas aplicações dos surfactantes, como a solubilização de compostos hidrofóbicos, dependem da existência de micelas no sistema. A CMC depende da natureza química do surfactante, do solvente, da temperatura e de aditivos como eletrólitos e substâncias orgânicas. Um exemplo disso foi ressaltado por Alexandridis e colaboradores (1994) que utilizaram um método de solubilização de um corante para investigar a CMC de uma série de Pluronics; por meio dos seus resultados foi possivel observar que a CMC do Pluronic $^{\circledR}$ F127 diminui drasticamente com a diminuição da temperatura (ALEXANDRIDIS et al., 1994).

O uso de micelas como nanocarreadores de fotossensibilizantes na aplicação da terapia fotodinâmica já foi investigado por JIN e colaboradores (2015) que utilizaram este sistema carreando Zinco-Ftalocianina $(\mathrm{ZnPc})$ no tratamento de psoríase em modelo animal. Os pesquisadores compararam o efeito da salina, a luz ou a formulação nanoestruturada da ZnPc apenas, e a combinação da luz e a formulação (a TFD). Como resultado foi observado, na análise histopatológica, a quase total cura da psoríase (JIN et al, 2015).

\subsection{Justificativa}

Devido a alta letalidade do câncer de pele melanoma, novos tratamentos vêm surgindo para melhorar a terapêutica dessa patogenia, uma vez que os tratamentos quimioterápicos existentes tem-se mostrado pouco eficazes contra a doença, além de trazer efeitos adversos, alta recidivação do câncer e uma baixa taxa de cura. Uma nova alternativa para o tratamento do melanoma metastático é a terapia fotodinâmica, uma modalidade terapêutica não invasiva, de baixo custo e que não necessita a internação do paciente.

O emprego do agente fotossensibilizante Alumínio-Cloro-Ftalocianina carreado por micelas de Pluronic ${ }^{\circledR}$ F127 na terapia fotodinâmica torna-se uma ferramenta potencial, pois se trata de um agente (AICIPC) com alta eficácia na TFD, carreado por um sistema nanoestruturado com vantagens farmacocinéticas bastante relevantes, como o nível de absorção do FS em células tumorais potencializado e 
boa biocompatibilidade, evitando assim sua degradação imediata no organismo. Assim, a avaliação da eficácia deste sistema no tratamento do melanoma é de fundamental importância na busca de novas e melhores modalidades terapêuticas.

\section{OBJETIVO}

O objetivo deste estudo é avalizar a eficácia da terapia fotodinâmica mediada pelo fotossensibilizante Alumínio-Cloro-ftalocianina em micelas de Pluronic ${ }^{\circledR}$ F127 para o tratamento de melanoma murino metastático in vitro.

\section{1 Objetivos específicos}

Para alcançar o objetivo deste estudo, foram pontuados os seguintes objetivos específicos:

- Preparação de nanoformulações de micelas de Pluronic ${ }^{\circledR}$ F127 com diferentes concentrações do fotossensibilizante Alumínio-Cloro-ftalocianina (NP F127/AICIPc);

- Caracterização físico-química das nanoformulações preparadas, determinando o diâmetro hidrodinâmico, o índice de polidispersão, o potencial zeta e o pH;

- Avaliação da estabilidade coloidal das nanoformulações ao longo do tempo, quando armazenadas sob diferentes temperaturas;

- Caracterização fotofísica das nanoformulações preparadas, determinando o espectro de absorbância e emissão de fluorescência;

- Avaliação da eficácia das nanoformulações na geração de oxigênio singleto;

- Determinação da toxicidade da luz LED na viabilidade de células de melanoma (B16F10) e em uma linhagem de melanoma modificada para a expressão de luciferase (B16F10FF) na ausência da nanoformulação em cultura destas células;

- Determinação da toxicidade das nanoformulações na viabilidade das duas linhagens de células de melanoma in vitro sem a irradiação da luz LED; 
- Avaliação da eficácia de terapia fotodinâmica pela viabilidade das células de melanoma (B16F10 e B16F10FF) in vitro na presença de Alumínio-CloroFtalocianina em micelas de Pluronic $^{\circledR}$ F127;

- Avaliação da eficácia de duas sessões de terapia fotodinâmica mediada por Alumínio-Cloro-Ftalocianina em micelas de Pluronic ${ }^{\circledR}$ F127 no tratamento de melanoma in vitro (B16F10FF), na condição em que se obteve a maior eficácia quando uma única sessão tenha sido aplicada. Esta avaliação será corroborada por duas metodologias distintas: viabilidade celular por MTT e proliferação celular em tempo real por RTCA.

Vale ressaltar que a utilização de células de melanoma modificadas para a expressão de luciferase e por consequente, a avaliação da eficácia da terapia fotodinâmica mediada por Alumínio-Cloro-ftalocianina em micelas de Pluronic ${ }^{\circledR}$ F127 nestas células, permitirá uma melhor adequação do delineamento experimental no modelo em camundongos para este tipo de tumor, principalmente como ferramenta de monitoramento da evolução tumoral e seu tratamento por meio de sistema de bioimageamento.

\section{MATERIAL E MÉTODOS}

\subsection{Equipamentos, materiais e reagentes}

Os principais equipamentos, materiais e reagentes que foram utilizados estão listados nas tabelas 2, 3 e 4, respectivamente.

Tabela 2: Lista de Equipamentos utilizados.

\begin{tabular}{ll}
\hline Equipamentos & Fabricante \\
\hline Balança analítica Série AUY-220 & Shimadzu $^{\circledR}$, BRA \\
Banho-Maria NT 245 & Nova Técnica, BRA \\
Câmara de Neubauer & Optik-Labor Frischknecht, Suíça \\
Constant Current LED Driver JD- & Zhuhai Tauras Technologies Co., Ltd., \\
$350 \mathrm{~mA}$ & China \\
\hline
\end{tabular}


Controlador RCD-24-0.35N

Espectrofotômetro Spectramax M2

Espectrofotômetro Portátil

Fluxo laminar unidirecional CFV12

Incubadora de célula

LED modelo XL001WP01NRC660

Microscópio de luz invertido CK2

Potencímetro digital Fieldmax II-TO

Vórtex Mixer XH-C

$x$ CELLigence DP Real-Time Cell

Analyzer (RTCA)

Zetasizer Nano ZS 90
Recom Power, Inc., ALE

Molecular Devices ${ }^{\circledR}$, LLC, USA

Ocean Optics Inc., EUA

VecoFlow, BRA

Thermo Scientific ${ }^{\text {TM }}$ Forma $^{\text {TM }}$ Steri-

Cycle $^{\mathrm{TM}}$

Shenzhen Sealand Optoelectronics ${ }^{\odot}$ Ltd.,

China

Olympus Optical Co, Ltd., Japão

Coherent Inc., EUA

Notek Medical ${ }^{\circledR}$, EUA

ACEA Bioscience Inc., EUA

Malvern Instruments, Worcestershire, Insight ${ }^{\circledR}$, UK

Tabela 3: Lista de Materiais utilizados.

\begin{tabular}{ll}
\hline Materias & Fabricante \\
\hline Criotubos & TPP $^{\circledR}$, ALE \\
Cubeta de quartzo & SPLabor, Baril \\
Lamínula de microscopia & Perfecta, BRA \\
Microtubo tipo eppendorf $2 \mathrm{~mL}$ & E-Lab Comerce $^{\circledR}$, Brasil \\
Papel filtro & J. Prolab, BRA \\
Papel indicador de pH $(0-14)$ & Merk $^{\odot}$, Alemanha \\
Placa de cultivo de células (24 & TPP $^{\circledR}$, ALE \\
poços) de poliestireno & \\
Placa de cultivo de células (96 poços) & TPP $^{\circledR}$, ALE \\
de poliestireno & \\
Seringa 20 mL BD Plastipak & \\
\hline
\end{tabular}


Tabela 4: Reagentes utilizados.

\begin{tabular}{|c|c|}
\hline Reagente & Fabricante \\
\hline Azul tripan & Sigma-Aldrich $^{\odot}$, EUA \\
\hline Antibiótico Pen-Strep & Gibco $^{\circledR}$ Invitrogen ${ }^{\mathrm{TM}}$, EUA \\
\hline Bicarbonato de sódio ReagentPlus ${ }^{\circledR}$ & Sigma-Aldrich $^{\odot}$, EUA \\
\hline Cloro-alumínio-ftalocianina (AICIPC) & Sigma-Aldrich $^{\oplus}$, BRA \\
\hline Dimetilsulfóxido (DMSO) & Macron $^{\mathrm{TM}}$ Chemicals, Avantor ${ }^{\mathrm{TM}}$ \\
\hline $\begin{array}{l}\text { Dulbecco`s Modified Eagle Medium } \\
\text { (DMEM) }\end{array}$ & Gibco Life Technologies ${ }^{\circledR}$, Ltda., EUA \\
\hline DBF (1,3-difenilisobenzofurano) & Sigma-Aldricht $^{\oplus}, A L E$ \\
\hline Pluronic $^{\circledR} \mathrm{F} 127$ & Sigma-Aldrich $^{\odot}$ (St. Louis, MO, EUA) \\
\hline Soro fetal bovino & Gibco® Invitrogen ${ }^{\mathrm{TM}}, \mathrm{EUA}$ \\
\hline Tampão Fosfato Salina (PBS) & Laborclin,BRA \\
\hline Tripsina-EDTA & Gibco $^{\circledR}$, EUA \\
\hline
\end{tabular}

\subsection{Preparação de micelas de Pluronic ${ }^{\circledR}$ F127 com Alumínio-Cloro-Ftalocianina (NP F127/AICIPc)}

Para a síntese de micelas de Pluronic ${ }^{\circledR}$ F127 com o fotossensibilizante AICIPc (NP F127/AICIPc) foi preparada uma solução do copolímero Pluronic ${ }^{\circledR}$ em tampão fosfato salina (PBS) estéril, utilizando a proporção de 1,15\% para $3 \%(p / v)$. 0 copolímero foi solubilizado em PBS sob agitação por 30 minutos. Em seguida, a solução foi filtrada em filtro Millipore ${ }^{\circledR}$ em fluxo laminar e aliquotada em seis tubos com volume de $5 \mathrm{~mL}$ para a adição do agente fotossensibilizante AICIPc, como ilustrado na figura 09. 


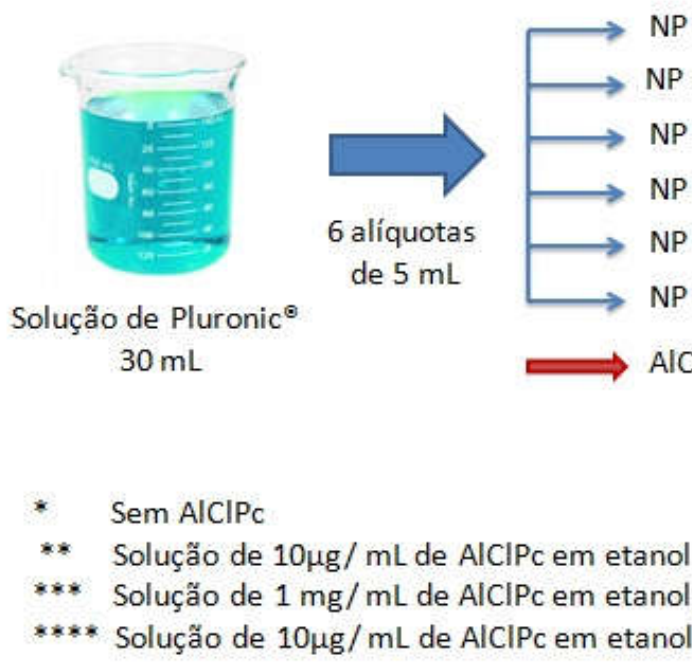

Figura 09. Esquema de preparação das amostras de micelas de Pluronic ${ }^{\circledR} \mathrm{F} 127$ com diferentes concentrações de alumínio-cloro-ftalocianina (AICIPc).

Para a incorporação da AICIPc foram preparadas duassoluções padrão de $1 \mathrm{mg} / \mathrm{mL}$ e $10 \mu \mathrm{g} / \mathrm{mL}$ de AICIPc. Nas soluções padrão foi utilizado etanol (P.A) para a solubilização do FS, uma vez que este, tem caráter hidrofóbico e sua solubilização não se dá em água (de caráter polar) Foram então produzidas amostras de micelas NP F127/AICIPc em três concentrações diferentes, além de uma amostra constituída apenas de Pluronic ${ }^{\circledR} \mathrm{F} 127$, sem adição de AICIPc, e outra amostra contendo apenas o fotossensibilizante sem o copolímero Pluronic ${ }^{\circledR}$ F127,ou seja, o FS livre, solubilizado em etanol, conforme mostra a tabela 4. As amostras preparadas foram homogeneizadas em vórtex a $134 \mathrm{~g}$ por 5 minutos para favorecer a ligação do copolímero Pluronic com a AICIPc na formação da micela.

A razão de preparar diferentes concentrações de amostras de micelas foi determinar qual a concentração micelar crítica (CMC) ideal para obter amostras que carregassem a maior quantidade de fotossensibilizante e que não mudasse o seu estado físico de sol para gel; solução coloidal, viabilizando o seu futuro emprego nos estudos in vitro e in vivo. As formulações foram preparadas pela bióloga Karen Happy-Py Daniel, no Laboratório de Nanobiotecnologia da Universidade de Brasília, 
de acordo com a necessidade dos experimentos. Vale ressaltar que a preparação destas micelas seguiu a metodologia descrita por ESCOBAR-CHAVÉZ e colaboradores (2006).

Tabela 5: Relação da preparação das amostras de micelas de pluronic F127 com diferentes concentrações de Alumínio-Cloro-Ftalocianina (AICIPc).

\begin{tabular}{|c|c|c|c|c|}
\hline Amostra & $\begin{array}{c}\text { Solução de } \\
\text { Pluronic F127 } \\
\text { (mL) }\end{array}$ & $\begin{array}{c}\text { Solução de } \\
\text { AICIPc* }^{*} \\
(\mu L)\end{array}$ & $\begin{array}{c}\text { PBS } \\
\text { estéril } \\
(\mu L) \\
\end{array}$ & $\begin{array}{c}\text { Etanol } \\
\text { estéril } \\
(\mu \mathrm{L}) \\
\end{array}$ \\
\hline NP F127 & 5 & - & - & - \\
\hline $\begin{array}{c}\text { NP F127/AICIPC } \\
1 \mu \mathrm{g} / \mathrm{mL}\end{array}$ & 5 & 5 & - & - \\
\hline $\begin{array}{c}\text { NP F127/AICIPC } \\
5 \mu \mathrm{g} / \mathrm{mL}\end{array}$ & 5 & 25 & - & - \\
\hline $\begin{array}{l}\text { NP F127/AICIPC } \\
10 \mu \mathrm{g} / \mathrm{mL}\end{array}$ & 5 & 50 & - & - \\
\hline $\mathrm{AICIPC}$ & - & 10 & 9.900 & 90 \\
\hline
\end{tabular}

\subsection{Caracterização e avaliação da estabilidade coloidal das micelas de Pluronic ${ }^{\circledR}$ F127 com Aluminio-Cloro-Ftalocianina (NP F127/AICIPc)}

Para caracterizar e avaliar a estabilidade das diferentes formulações de micelas de Pluronic F127/AICIPc (tabela 5), um lote de cada uma das formulações foi preparado em volume final de $30 \mathrm{~mL}$ Logo após o preparo, as propriedades coloidais como o diâmetro hidrodinâmico (DH), o índice de polidispersão (IPD), o potencial zeta $(\mathrm{Pz})$ e potencial hidrogeniônico $(\mathrm{pH})$ foram analisadas.

Em seguida as formulações foram aliquotadas igualmente em três tubos com volume final de amostra de $10 \mathrm{~mL}$, e cada tubo foi armazenado em diferentes temperaturas tais como: no refrigerador a $4{ }^{\circ} \mathrm{C}$; sob a bancada de laboratório a temperatura ambiente, aproximadamente $25^{\circ} \mathrm{C}$ e em estufa seca a $37^{\circ} \mathrm{C}$. 
Para avaliar a estabilidade ao longo do tempo das formulações armazenadas sob diferentes temperaturas, as mesmas variáveis analisadas, logo após a preparação, também foram mensuradas por três meses, sendo que no primeiro mês as medidas foram realizadas semanalmente, e nos meses seguintes elas foram analizadas quinzenalmente.

Os dados referentes ao diâmetro hidrodinâmico $(\mathrm{DH})$ e índice de polidispersão (IPD) foram obtidos por dispersão dinâmina da luz (DLS) e o potencial zeta (Pz) foi obtido por dispersão de luz eletroforética em Zetasizer. Os dados referentes ao $\mathrm{DH}$ foram realizados em ângulo de detecção de $90^{\circ}$ com duração de $120 \mathrm{~s}$ e são apresentados por dispersão numérica. Os dados referentes ao $\mathrm{Pz}$ foram obtidos a partir de um potencial estabelecido no zetasizer de $\sim 150 \mathrm{mV}$ e expressos como a média dos valores da mobilidade eletroforética utilizando a Equação de Smoluchowski (TANDON et al, 2008). Todos os parâmetros foram avaliados usandose $1 \mathrm{~mL}$ de cada formulação, sem diluição, de modo a não alterar a interação estrutural do polímero com o fotossensibilizante.

O potencial hidrogeniônico $(\mathrm{pH})$ das diferentes formulações recém preparadas, assim como das armazenadas nas três distintas temperaturas foi mensurado com papel indicador de $\mathrm{pH}(0-14)$ diretamente nas soluções antes das análises dos demais parâmetros.

\subsection{Caracterização fotofísica das micelas de Pluronic ${ }^{\circledR}$ F127 com Aluminio- Cloro-Ftalocianina (NP F127/AICIPc)}

Como parâmetro complementar à caracterização das NP F127/AICIPc, os espectros de absorção (absorbância) e emissão de fluorescência das diferentes formulações foram obtidos utilizando-se o espectrômetro (Spectra Max). Para tanto, uma alíquota de $200 \mu \mathrm{L}$ das amostras foram colocadas em placas de cultura de 96 poços e então excitadas a um comprimento de onda de 350 a $750 \mathrm{~nm}$. Esta metodologia foi adaptada de NUNES (2012). As amostras foram analisadas em triplicata em todos os experimentos. 


\subsection{Avaliação da Geração de Oxigênio Singleto pelas micelas de Pluronic ${ }^{\circledR}$ F127 com Aluminio-Cloro-Ftalocianina (NP F127/AICIPc)}

Visando determinar se as formulações de NP-AICIPc eram eficazes em gerar oxigênio singleto $\left({ }^{1} \mathrm{O}_{2}\right)$ ao serem fotoativadas, foi usado o método de degradação do benzofurano- ${ }^{1} \mathrm{O}_{2}$-dependente, segundo metodologia adaptada de SPILLER e colaboradores (1998). O reagente 1,3-difenil-isobenzofurano (DBF) é uma molécula que reage irreversivelmente com $\mathrm{O}^{1} \mathrm{O}_{2}$, extinguindo sua absorbância quando excitado em comprimento de onda próximo a $410 \mathrm{~nm}$. Conforme o DBF é decomposto pela geração de ${ }^{1} \mathrm{O}_{2}$, a sua absorbância é reduzida de forma proporcional à quantidade de moléculas de oxigênio singleto gerada. Assim, a absorbância decai de forma diretamente proporcional à geração $\operatorname{de}^{1} \mathrm{O}_{2}$, o que permite sua quantificação percentual.

Assim, para este experimento, foi preparada uma solução de a $0,225 \mathrm{mg} / \mathrm{mL}$ de DBF diluída em etanol. Em seguida, a solução foi agitada em vórtex por dois minutos e levada ao banho ultrassônico até completa homogeneização da solução e a mesma foi utilizada no máximo duas horas após seu preparo, devido à rápida degradação de DBF em solução. Para o ensaio, $10 \mu \mathrm{L}$ da solução de DBF e $190 \mu \mathrm{L}$ de uma das formulações NP F127/AICIPc foram adicionados à placas de cultura de 96 poços e a degradação de DBF foi acompanhada pela leitura da absorbância (410 $\mathrm{nm}$ ), no espectrofotômetro (Spectra Max), após sucessivos ciclos de irradiação de LED de 10 segundos cada, correspondente a fluência de energia de $0,4 \mathrm{~J} / \mathrm{cm}^{2}$ por ciclo de irradiação. Após 10 ciclos, a fluência total recebida pela amostra foi de 4 $\mathrm{J} / \mathrm{cm}^{2}$.

\subsection{Ensaios biológicos in vitro}


Todos os procedimentos in vitro foram realizados em câmara de fluxo laminar previamente limpa com álcool $70 \%$ e esterilizada com luz ultravioleta por 20 minutos. Os materiais utilizados eram novos e esterilizados.

\section{Ensaios in vitro}

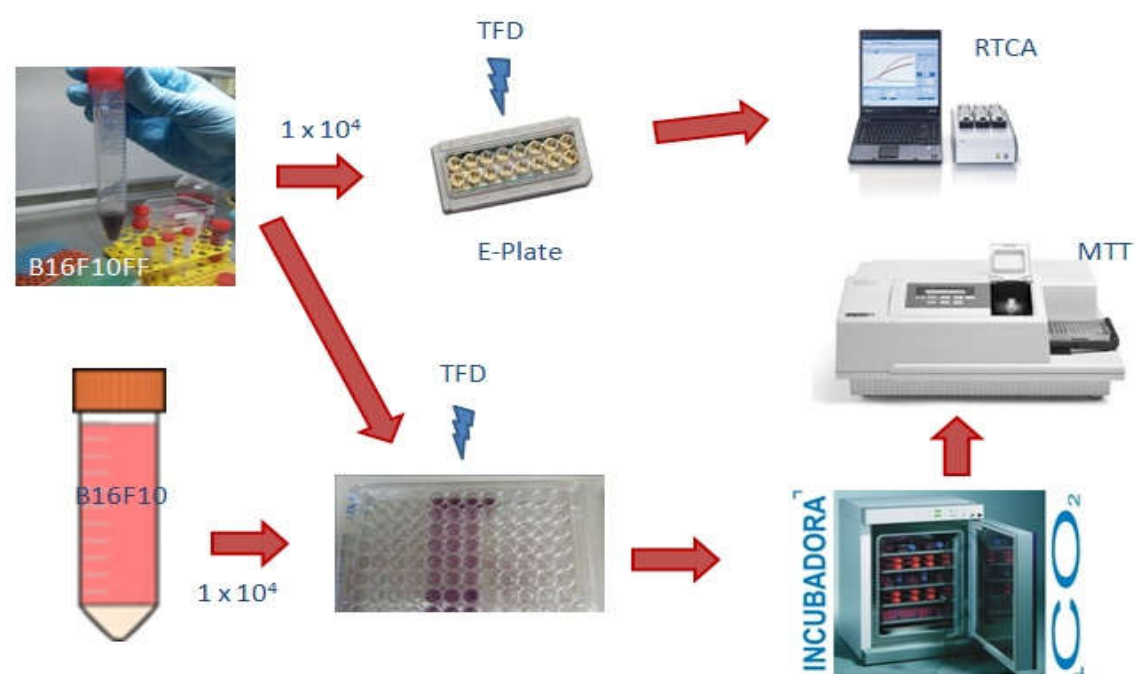

Fifura 10. Esquema dos ensaios in vitro com células B16F10 e B16F10FF. Células foram plaqueadas e após 24 horas foi realizada a aplicação da TFDpara os ensaios de: efeito do LED nas células tumorais, viabilidade celular da B16F10 e B16F10FF por MTT e proliferação celular pelo RTCA, ambos realizados após aplicação de TFD a $85,1 \mathrm{~J} / \mathrm{cm}^{2}$.

\subsubsection{Linhagens celulares}

Os ensaios in vitro foram realizados em linhagens celulares imortalizadas murinas de melanoma maligno B16F10 (ATCC $^{\odot}$ CRL-6475 $^{\mathrm{TM}}$ ) e melanoma modificada com FireFly Luciferase, B16F10FF. A linhagem selvagem foi adquirida da ATCC $^{\odot}$ (American Type Culture Collection - Manassas, VA, EUA) por meio do banco de células do Rio de Janeiro e a linhagem modificada foi gentilmente cedida pelo Laboratório do Hemocentro de Ribeirão Preto. 


\subsubsection{Manutenção e passagem das células}

Neste estudo, as linhagens celulares utilizadas estavam preservadas em criotubos contendo $5 \%$ de DMSO e $95 \%$ de soro fetal bovino (SFB) e armazenadas em tanque de nitrogênio líquido em Câmara Fria no Laboratório de Nanobiotecnologia da Universidade de Brasília - UnB. Os criotubos das células B16F10 e B16F10FF, contendo $1 \times 10^{6}$ células $/ \mathrm{mL}$, foram retirados do estoque de nitrogênio líquido e descongelados à temperatura ambiente. Cada alíquota de 1000 $\mu \mathrm{L}$ de suspensão celular foi transferida para um tubo de $15 \mathrm{~mL}$, e resuspendida com $1 \mathrm{~mL}$ de SFB, seguida da adição de mais $1 \mathrm{~mL}$ de DMEM. A suspensão de células selvagens foi centrifugada a $302 \mathrm{~g}$, por 5 min e o precipitado resuspendido em $1 \mathrm{~mL}$ de DMEM completo (DMEM suplementado com 10\% de SFB, $1 \%$ de antibiótico Pen Strep, composto por penicilina $100 \mathrm{U} / \mathrm{mL}$ e estreptomicina $100 \mu \mathrm{g} / \mathrm{mL}$, com pH ajustado para 7,2), seguido da transferência para a garrafa de cultivo celular de 25 $\mathrm{cm}^{2}$ que já continha $3 \mathrm{~mL}$ do meio de cultivo. As garrafas foram mantidas em incubadora, cuja atmosfera era de $5 \%$ de $\mathrm{CO}_{2}$ em ar, a umidade saturada (80\%) e a temperatura de $37^{\circ} \mathrm{C}$. Após 24 horas o meio de cultivo foi substituído por meio novo.

Para acompanhar o crescimento celular e identificar qualquer mudança nas características morfológicas e detectar possíveis contaminações bacterianas ou fúngica, o cultivo celular foi observado e monitorado em microscópio de luz invertido, periodicamente.

Ao atingir $75-80 \%$ de confluência na superfície da garrafa de cultivo, $1 \times 10^{4}$ células foram transferidas para uma nova garrafa. Para tal, o meio de cultivo foi removido e a monocamada de células tratada com $2 \mathrm{~mL}$ de solução Trpsina-EDTA por três minutos a $37^{\circ} \mathrm{C}$. Em seguida, foram acrescentados $2 \mathrm{~mL}$ de meio de cultura para a inativação da enzima e centrifugação por dois minutos. Após a remoção do sobrenadante, as células foram resuspendidas em $1 \mathrm{~mL}$ de meio de cultivo, dos quais $100 \mu \mathrm{L}$ foramtransferidos para uma nova garrafa de cultivo de $25 \mathrm{~cm}^{2}$ com 3 $\mathrm{mL}$ de meio e levadas novamente à incubadora. Para a manutenção das células, renovou-se o meio de cultura a cada 48-72 h. A cada transferência de células para 
uma nova garrafa contava-se o número de células e registrava-se uma nova passagem celular.

\subsubsection{Contagem de células}

Para os testes in vitro o número de células plaqueadas foi calculado utilizando o método de exclusão por Azul Trypan e a contagem de células em câmara de Neubauer. Para tanto, após a tripsinização da monocamada de células e a resuspensão em $1 \mathrm{~mL}$ de meio de cultivo (descrito na seção 3.6.2), $10 \mu \mathrm{L}$ desta suspensão eram adicionados a $90 \mu \mathrm{L}$ de solução de Azul Trypan. Este corante não é capaz de penetrar em células que apresentam a membrana plasmática intacta, 0 que torna possível a distinção das células viáveis a partir do princípio de exclusão. Dez microlitros do preparado contendo o corante eram retirados e aplicados em câmara de Neubauer. A concentração de células era determinada baseando-se em seus quadrantes laterais e de acordo com a equação abaixo:

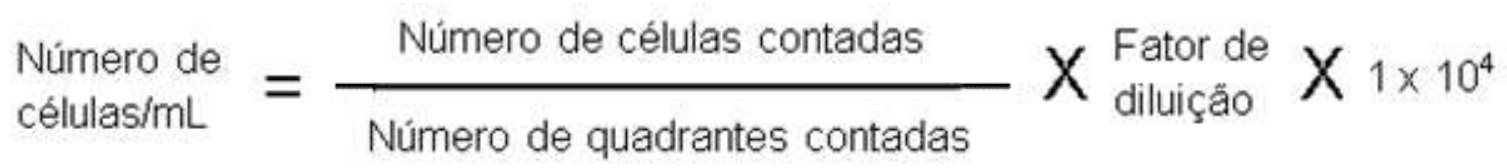

\subsubsection{Avaliação da viabilidade celular pelo ensaio do MTT}

O princípio desse método consiste em medir indiretamente a viabilidade celular pela absorção do sal tetrazólio MTT \{brometo de [3-(4,5-dimetiltiazol-2-il)-2,5difeniltetrazólio]\} pelas células, sendo reduzido no interior da mitocôndria, por meio da atividade enzimática de desidrogenases, ao produto chamado azul de formazan (MOSMANN, 1983). Assim, somente as células viáveis com mitocôndrias ativas, reduzem o MTT, de forma que a quantificação dos cristais de formazan detectada, por espectrofotometria, permite fazer uma correlação com a proporção de células vivas. 
Após 24 horas que as células foram submetidas aos diferentes tratamentos, 0 meio de cultivo de cada poço era substituído por $150 \mu \mathrm{L}$ de meio novo contendo uma solução de MTT $(5 \mathrm{mg} / \mathrm{mL})$ a $10 \%$. As células foram levadas à incubadora a $37^{\circ} \mathrm{C}$ por duas horas e meia para a metabolização do MTT. Após esse período, o meio contendo a solução de MTT foi removido e os cristais de formazan de cada poço foram solubilizados pela adição de $200 \mu \mathrm{L}$ de DMSO. Após homogeneização dos cristais, foi realizada a leitura de absorbância a $595 \mathrm{~nm}$, em espectrofotômetro (SpectraMax) conjugado com leitora de placas. O ensaio foi realizado com as amostras em triplicata, seguindo o protocolo estabelecido por SILVEIRA-LACERDA (2009).

\subsubsection{A fonte luminosa LED (Light Emitting Diode)}

A fonte de luz utilizada na avaliação da geração de oxigênio singleto e nos experimentos in vitro foi a mesma. Foram utilizados bancos de 20 diodos emissores de luz (LED - do inglês Light Emitting Diode). O circuito de alimentação foi montado pelo Professor Dr. Paulo Souza do Instituto de Física da Universidade de Brasília. O controle da corrente de alimentação capaz de garantir a estabilidade da iluminação foi realizado por um controlador LED, especificado na tabela 2 .

O espectro de emissão do LED foi determinado utilizando um espectrofotômetro portátil e um potencímetro digital, ambos especificados na tabela 2. A partir do valor do espectro de emissão do LED foi definido o valor de potência máxima do LED e os valores de potência em função da distância, assim como a posição do banco de LEDs em relação ao material a ser irradiado. Para garantir a reprodutibilidade da intensidade luminosa emitida pelo banco de LEDs, optou-se por realizar periodicamente a aferição da energia por unidade de tempo mediante potencímetro. As medidas registradas pelo potencímetro e a área do detector permitiram determinar que a fonte de luz possuía densidade de potência de 0,04 $\mathrm{W} / \mathrm{cm}^{2}$.

Dessa forma, a fluência aplicada nos ensaios foi determinada segundo a equação abaixo: 


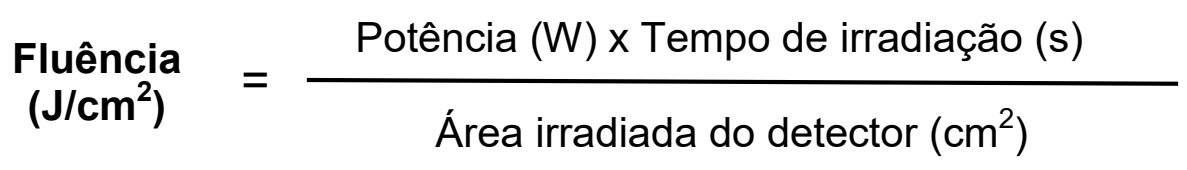

Estudos prévios desenvolvidos por MONGE-FUENTES (2014), utilizando este equipamento, mostrou que a fluência necessária para gerar citotoxicidade nas células de melanoma murino (B16F10) utilizadas neste estudo, foi de $85,01 \mathrm{~J} / \mathrm{cm}^{2}$, com $5 \mathrm{~cm}$ de distância, em relação ao fundo da placa, em ângulo reto com 10 minutos de irradiação

\subsubsection{Determinação da toxicidade do LED na viabilidade celular}

Este ensaio foi realizado com a finalidade de determinar se apenas a irradiação da luz LED, sem a presença de micelas de Pluronic ${ }^{\circledR}$ F127 com Aluminio-CloroFtalocianina (NP F127/AICIPc) era capaz de induzir citotoxicidade e assim conduzir à morte celula (Figura 11). As condições de irradiação de luz LED utilizada neste ensaio foram as mesmas utilizadas em estudo prévio desenvolvido por MONGEFUENTES (2014), conforme descrito na seção 3.6.5. O experimento foi baseado em resultados desenvolvidos previamente por MONGE-FUENTES (2014).

Para tanto, $1 \times 10^{4}$ células/poço foram cultivadas em placas de 96 poços nas condições descritas na seção 3.6.2. Após o período de 24 horas o meio de cultivo foi descartado, e as células foram lavadas por duas vezes com PBS e mantidas em 100 $\mu \mathrm{L}$ de PBS. A placa foi então irradiada com o LED, conforme seção 3.6.5. Após o tratamento, o PBS foi removido e as células foram cultivadas por 24 horas, quando então o possível efeito do $L E D$ na viabilidade celular foi determinado por MTT conforme descrito na seção 3.6.4. Foram realizados três experimentos independentes. 


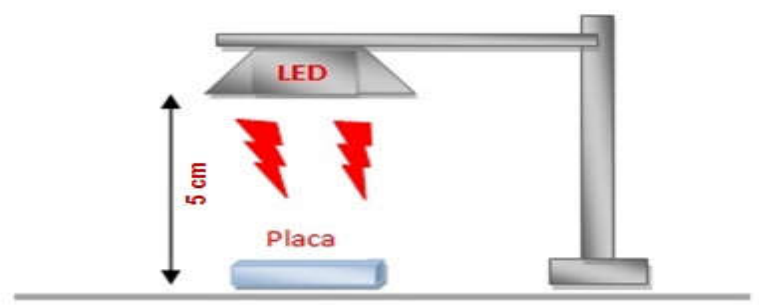

Figura 11: Esquema ilustrativo do LED em fluxo laminar utilizando um suporte de metal. Diodo emissor de luz com 85,1 J/cm2 (LED) para irradiação de placa de 96 poços com células B16 F10 e B16F10FF.

\subsubsection{Determinação da toxicidade das micelas de Pluronic ${ }^{\circledR}$ F127 com Aluminio-Cloro-Ftalocianina (NP F127/AICIPc) na viabilidade celular}

Este ensaio foi realizado com a finalidade de determinar se apenas a formulação de micelas de Pluronic $^{\circledR}$ F127 com Aluminio-Cloro-Ftalocianina (NP F127/AICIPc), ou as micelas de Pluronic ${ }^{\circledR}$ F127 sem o fotossensibilizante (NP F127) e ainda apenas o Aluminio-Cloro-Ftalocianina, sem qualquer irradiação da luz LED, eram capazes de induzir citotoxicidade e assim conduzir à morte celular.

Para tanto, $1 \times 10^{4}$ células/poço foram cultivadas em placas de 96 poços nas condições descritas na seção 3.6.2. Após o período de 24 horas o meio de cultivo foi descartado, e as células lavadas por duas vezes com PBS e então foram adicionados $100 \mu \mathrm{L}$ de NP F127/AICIPc, nas três diferentes concentrações (tabela 4), assim como de NP F127 e 0,01 $\mu \mathrm{g} / \mathrm{mL}$ de AICIPc. A placa foi protegida de irradiação luminosa pela cobertura com papel alumínio. As células permaneceram expostas a estas soluções por 15, 20 e 25 minutos, na incubadora de células. Em seguida, a placa foi transferida para o fluxo laminar e as células foram lavadas por duas vezes com PBS. A fim de manter o mesmo tempo experimental de quando são irradiadas, as células 
permaneceram em PBS por mais 10 minutos, no interior do fluxo laminar. Após o tratamento, o PBS foi removido e as células cultivadas sob as condições descritas na seção 3.6.2 por 24 horas, quando então a viabilidade celular foi determinada por MTT conforme descrito na seção 3.6.4. Foram realizados três experimentos independentes e os grupos experimentais em triplicatas.

\subsubsection{Avaliação da Terapia Fotodinâmica mediada por micelas de Pluronic ${ }^{\circledR}$ F127 com Aluminio-Cloro-Ftalocianina (NP F127/AICIPc)}

Este ensaio foi realizado com a finalidade de determinar a eficácia da formulação de micelas de Pluronic $^{\circledR}$ F127 com Aluminio-Cloro-Ftalocianina (NP F127/AICIPc) como fotossensibilizante a ser empregado na terapia fotodinâmica, avaliando a viabilidade celular.

Para tanto, $1 \times 10^{4}$ células/poço foram cultivadas em placas de 96 poços. Após o período de 24 horas o meio de cultivo foi descartado, e as células lavadas por duas vezes com PBS e então foram adicionados $100 \mu \mathrm{L}$ de NP F127/AICIPc, nas três diferentes concentrações (tabela 4), assim como de NP F127 e AICIPc. A placa foi protegida de irradiação luminosa pela cobertura com papel alumínio. Os tempos de incubação foram previamente analisados para a escolha de um tempo inicial de incubação. As células permaneceram expostas a estas soluções por 15, 20 e 25 minutos, na incubadora de células. Em seguida, a placa foi transferida para o fluxo laminar e as células foram lavadas duas vezes com PBS e mantidas em $100 \mu \mathrm{L}$ desta solução, quando então a placa foi irradiada com o LED, conforme seção 3.6.5. Após o tratamento, o PBS foi removido e as células cultivadas sob as condições descritas na seção 3.6 .2 por 24 horas, quando então a viabilidade celular foi determinada por MTT conforme descrito na seção 3.6.4. Foram realizados três experimentos independentes e os grupos em triplicatas.

\subsubsection{Avaliação da eficácia de duas sessões de Terapia Fotodinâmica mediada por micelas de Pluronic $^{\circledR}$ F127 com Aluminio-Cloro-Ftalocianina (NP F127/AICIPc)}


Este ensaio foi realizado com a finalidade de verificar se a aplicação de duas sessões de terapia fotodinâmica, com intervalo de 24 horas entre elas, aumentaria a eficácia da formulação de micelas de Pluronic $^{\circledR}$ F127 com Aluminio-CloroFtalocianina (NP F127/AICIPC), no tratamento de melanoma murino de células transformadas para a expressão de luciferase (B16F10FF), avaliando a viabilidade desta linhagem celular.

Os grupos que sofreram irradiação pelo LED, 24 horas após o plaqueamento, o meio de cultivo foi descartado, e as células lavadas por duas vezes com PBS e então foram adicionados $100 \mu \mathrm{L}$ de NP F127/AICIPc, nas três diferentes concentrações (tabela 5), assim como de NP F127 e AICIPc. As células permaneceram expostas a estas soluções por 15, 20 e 25 minutos, na incubadora de células. Em seguida, a placa foi transferida para o fluxo laminar e as células foram lavadas duas vezes com PBS e mantidas em $100 \mu \mathrm{L}$ desta solução, quando então a placa foi irradiada com o LED, conforme seção 3.6.5. Após o tratamento, o PBS foi removido e as células cultivadas sob as condições descritas na seção 3.6.2. Passadas 24 horas após a primeira aplicação de TFD, o meio de cultivo foi descartado e as células lavadas por duas vezes com PBS e então foram adicionados $100 \mu \mathrm{L}$ de NP F127/AICIPc, nas três diferentes concentrações (tabela 4), assim como de NP F127 e AICIPc. As células permaneceram expostas a estas soluções por 15, 20 e 25 minutos, na incubadora de células. Em seguida, a placa foi transferida para o fluxo laminar e as células foram lavadas duas vezes com PBS e mantidas em $100 \mu \mathrm{L}$ desta solução, e então a placa foi submetida a uma nova aplicação de TFD. Após o tratamento, o PBS foi removido e as células cultivadas sob as condições descritas na seção 3.6.2. Então, 24 horas após a segunda aplicação daterapia fotodinâmica, a viabilidade celular foi determinada por MTT conforme descrito na seção 3.6.4. Para isto, foram realizados três experimentos independentes em triplicata. 


\subsubsection{0 .Avaliação da eficácia de duas sessões de Terapia Fotodinâmica mediada por micelas de Pluronic ${ }^{\circledR}$ F127 com Aluminio-Cloro-Ftalocianina (NP F127/AICIPc), analisando a dinâmica de proliferação celular}

Para confirmar a eficácia do tratamento de melanoma murino de células transformadas para a expressão de luciferase (B16F10FF) com duas sessões de terapia fotodinâmica medicada por NP F127/AICIPc, a capacidade de proliferação destas células foi analisada. Utilizou-se o sistema $x$ CELLigence $^{\mathrm{TM}}$ (Roche/ACEA), que emprega o instrumento RTCA (Real Time Cell Analyzer) que é mantido dentro de uma incubadora de cultura de células e que utiliza placas com microelétrodos de ouro para monitorar a proliferação celular em tempo real, por meio da detecção automatizada do índice de biomassa celular determinado pela impedância eletrônica.

Vale ressaltar que este ensaio foi realizado somente sob as condições de tempo de exposição e concentração da formulação NP F127/AICIPc em que a aplicação de duas sessões de terapia fotodinâmica foi mais eficaz.

Para esse ensaio, primeiramente eram colocados $100 \mu \mathrm{L}$ de meio de cultura/poço em placa E-Plate16 (Roche/ACEA) para obter os valores basais. Uma vez estabilizado o sistema, $3 \times 10^{3}$ células sem tratamento, foram colocadas em cada poço. A placa foi mantida por 30 minutos no fluxo laminar, para a decantação das células e depois colocada no equipamento de RTCA, na incubadora de células A proliferação celular foi analisada durante $24 \mathrm{~h}$. Depois desse tempo, o sistema de detecção foi pausado, o meio de cultura desprezado, os poços lavados uma vez com PBS e em seguida as células foram expostas a $100 \mu \mathrm{L}$ de NP F127/AICIPc a 10 $\mu \mathrm{g} / \mathrm{mL}$. A placa foi protegida de irradiação luminosa pela cobertura com papel alumínio e mantida na incubadora de células por 25 minutos. Em seguida, a placa foi transferida para o fluxo laminar e as células foram lavadas por uma vez com PBS para eliminar resíduos da formulação e mantidas em $100 \mu \mathrm{L}$ desta solução, quando então metade da placa foi irradiada com o LED, conforme seção 3.6.5. e a outra metade foi protegida da irradiação luminosa por papel alumínio. Após o tratamento, o PBS foi substituído por meio de cultivo e a placa reconectada ao equipamento de RTCA na incubadora. Após 24 horas, o sistema foi novamente pausado, o meio de 
cultivo removido e as células lavadas por uma vez com PBS e mantidas em $100 \mu \mathrm{L}$ desta solução, mantendo as mesmas condições, quando então a mesma metade da placa previamente irradiada foi novamente irradiada com o LED, conforme seção 3.6.5. e a outra metade foi protegida da irradiação luminosa por papel alumínio. Após o tratamento, o PBS foi substituído por meio de cultivo e a placa reconectada ao sistema do RTCA na incubadora de células. Este experimento foi realizado com duas exposições as micelas, com dois processos de incubação e duas aplicações de TFD, ou seja, foi realizado conforme o ensaio de viabilidade celular do item 3.6.9. Ao longo de 163 horas (seis dias e 19 horas), o valor de impedância na placa foi mensurado a cada 30 minutos, sendo que a dinâmica da proliferação celular (índice celular em função do tempo) foi analisada utilizando o software RTCA (Roche/ACEA). Este ensaio foi realizado em septuplicata.

\subsection{Análise Estatística}

Os dados foram avaliados por meio de estatística paramétrica ou não paramétrica de acordo com a distribuição da normalidade. Para os dados paramétricos foram realizada ANOVA. O programa estatístico utilizado foi o GraphPad Prims 6 (GraphPad software, EUA).

\section{RESULTADOS}

\subsection{Caracterização coloidal das micelas de Pluronic ${ }^{\circledR}$ F127 com Alumínio-Cloro- Ftalocianina (NP F127/AICIPC)}

$\mathrm{Na}$ caracterização das diferentes amostras das micelas de Pluronic ${ }^{\circledR}$ F127 com Alumínio-Cloro-Ftalocianina (NP F127/AICIPc) foram avaliados, logo após o preparo, as seguintes propriedades coloidais: diâmetro hidrodinâmico (DH), o índice de polidispersão (IPD), o potencial zeta (Pz) e o potencial hidrogeniônico $(\mathrm{pH})$.

Os valores das propriedades coloidais avaliadas estão expressos na tabela 05. Observa-se que a formulação de micelas contendo $1 \mu \mathrm{g} / \mathrm{mL}$ de AICIPc apresentou 
um ligeiro aumento no diâmetro hidrodinâmico com a incorporação do fotossensibilizante quando comparado com a formulação de micelas sem AICIPc (NP F127). O índice de polidispersão também permaneceu bastante próximo ao da amostra de micelas sem o fotossensibilizante, indicando que esta quantidade de AICIPc incorporada nas micelas não alterou a monodispersão da formulação.

Como esperado, nas maiores concentrações de AICIPc incorporada nas micelas, 5 e $10 \mu \mathrm{g} / \mathrm{mL}$, observou-se um aumento significativo no diâmetro hidrodinâmico $(\mathrm{DH})$, quando comparado com as micelas sem o fotossensibilizante. Um aumento significativo do índice de polidispersão também foi observado na amostra com $5 \mu \mathrm{g} / \mathrm{mL}$ de AICIPc, mostrando que nesta concentração do fotossensibilizante incorporado, a formulação tornou-se polidispersa, após a preparação das amostras de micelas de Pluronic ${ }^{\circledR}$ F127 com Alumínio-CloroFtalocianina (NP F127/AICIPc) ou sem o fotossensibilizante (NP F127).

Tabela 06: Valores médios do diâmetro hidrodinâmico (DH), do índice de polidispersão (IPD), do potencial zeta ( $\mathrm{Pz}$ ) e do potencial hidrogeniônico $(\mathrm{pH})$ logo após o preraro das formulações.

\begin{tabular}{|c|c|c|c|c|}
\hline Formulações & $\mathrm{DH}(\mathrm{nm})$ & IPD & $\mathrm{Pz}(\mathrm{mV})$ & $\mathrm{pH}$ \\
\hline NP F127 & $25,88 \pm 0,42$ & $0,35 \pm 0,05$ & $-0,73 \pm 0,88$ & 6 \\
\hline $\begin{array}{l}\text { NP F127/AICIPC } \\
1 \mu \mathrm{g} / \mathrm{mL}\end{array}$ & $27,35 \pm 0,21$ & $0,34 \pm 0,02$ & $-2,52 \pm 0,01$ & 6 \\
\hline $\begin{array}{l}\text { NP F127/AICIPC } \\
5 \mu \mathrm{g} / \mathrm{mL}\end{array}$ & $71,33 \pm 3,16$ & $0,66 \pm 0,02$ & $-1,53 \pm 0,01$ & 7 \\
\hline $\begin{array}{l}\text { NP F127/AICIPc } \\
10 \mu \mathrm{g} / \mathrm{mL}\end{array}$ & $52,09 \pm 2,17$ & $0,33 \pm 0,17$ & $-0,37 \pm 0,01$ & 7 \\
\hline
\end{tabular}

Quanto ao potencial zeta $(\mathrm{Pz})$, observou-se na tabela 06 que as micelas mantêm a carga negativa após a incorporação do fotossensibilizante, até mesmo 
nas maiores concentrações de ALCIPc . Ainda pode-se observar que o potencial hidrogeniônico $(\mathrm{pH})$ das micelas nas duas maiores concentrações, tornou-se ligeiramente mais alcalino quando o fotossensibilizante foi incorporado.

\subsection{Avaliação da estabilidade coloidal das micelas de Pluronic ${ }^{\circledR}$ F127 com Alumínio-Cloro-Ftalocianina (NP F127/AICIPc)}

A determinação da estabilidade coloidal das micelas de Pluronic ${ }^{\circledR}$ F127 com diferentes concentrações de Alumínio-Cloro-Ftalocianina (NP F127/AICIPc), assim como das micelas sem o fotossensibilizante (NP F127) acondicionadas em diferentes temperaturas $\left(4{ }^{\circ} \mathrm{C}, \pm 25{ }^{\circ} \mathrm{C}\right.$ e $\left.37^{\circ} \mathrm{C}\right)$ foi realizada ao longo de 63 dias, sendo analisadas as mesmas propriedades coloidais: o diâmetro hidrodinâmico (DH), o índice de polidispersão (IPD), o potencial zeta (Pz) e o potencial hidrogeniônico $(\mathrm{pH})$.

A Figura 12 mostra a variação do diâmetro hidrodinâmico $(\mathrm{DH})$ das micelas de Pluronic ${ }^{\circledR}$ F127 sem o fotossensibilizante (NP F127, figura 12A) e com diferentes concentrações de Alumínio-Cloro-Ftalocianina (NP F127/AICIPc, figuras 12B, C e D) armazenadas ao longo de 42 dias, nas temperaturas de $4, \sim 25$ e $37^{\circ} \mathrm{C}$. Os valores obtidos entre 42 e 63 dias não foram inseridos, pois todas as amostras, sob as três diferentes temperaturas de armazenamento, tiveram o seu $\mathrm{DH}$ aumentado, em média, mais de 100 vezes, inviabilizando uma apresentação gráfica adequada. 

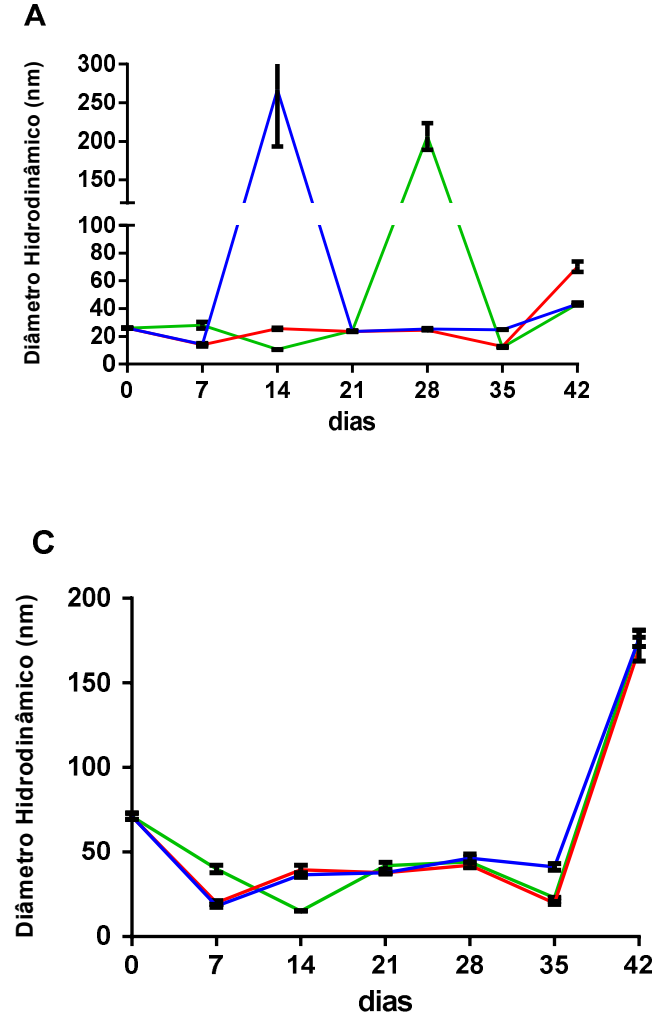

B

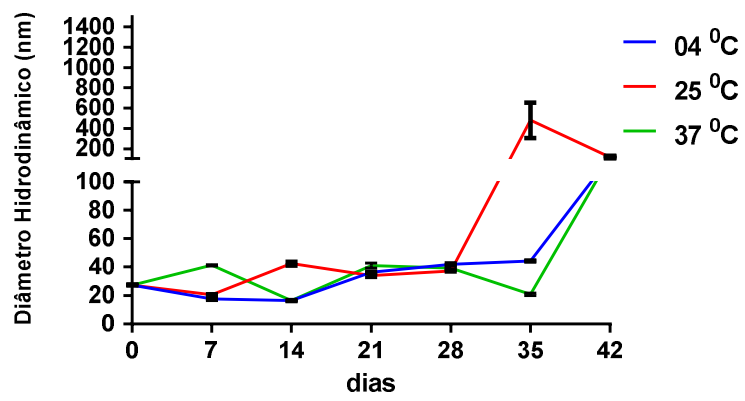

D

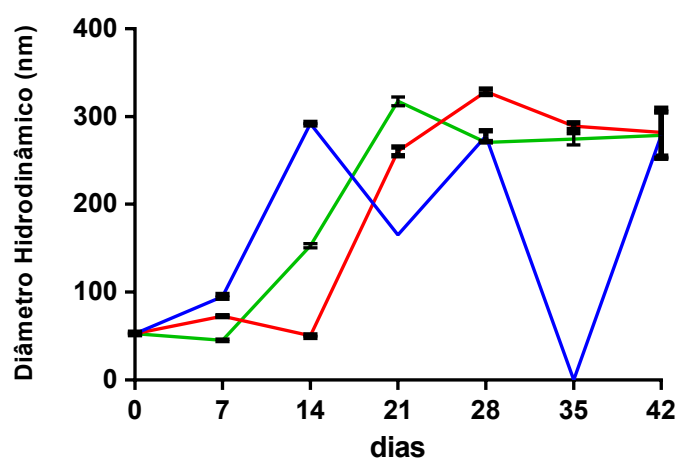

Figura 12. Variação do Diâmetro Hidrodinâmico (DH) por dispersão dinâmica de luz (DLS) das micelas de Pluronic ${ }^{\circledR} \mathrm{F} 127$, com ou sem fotossensibilizante armazenadas, sob as condições de $4{ }^{\circ} \mathrm{C}$ (linha azul), $\sim 25^{\circ} \mathrm{C}$ (linha vermelha) e $37^{\circ} \mathrm{C}$ (linha verde) ao longo de 42 dias. A- micelas sem AICIPc (NP F127). B- micelas com $1 \mu \mathrm{g} / \mathrm{mL}$ de AICIPc. C- micelas com $5 \mu \mathrm{g} / \mathrm{mL}$ de AICIPC. D- micelas com $10 \mu \mathrm{g} / \mathrm{mL}$ de AICIPC. Os dados estão representados como média \pm E.P.M. para triplicatas $(\mathrm{AICIPc}=$ Alumínio-Cloro-Ftalocianina).

Observou-se que na amostra contendo micelas sem AICIPc (Figura 12A), quando armazenada a $37{ }^{\circ} \mathrm{C}$, houve uma variação significativamente maior do valor médio do $\mathrm{DH}$, após 28 dias de estocagem. Esta variação não foi observada na amostra estocada a $\sim 25{ }^{\circ} \mathrm{C}$, comparado ao valor determinado logo após a preparação da amostra, ou seja, esta manteve-se em torno de $25 \mathrm{~nm}$. Após 14 dias, a amostra mantida a $4{ }^{\circ} \mathrm{C}$ também teve um aumento significativo do $\mathrm{DH}$, porém a partir do $21^{\circ}$ 
dia o seu valor médio de $\mathrm{DH}$ manteve-se próximo ao que foi determinado após a preparação da amostra, no período de até 42 dias.

A amostra contendo a menor concentração de fotossensibilizante incorporado às micelas (Figura 12B), quando mantida a $25^{\circ} \mathrm{C}$, teve uma variação não significativa do DH até 28 dias. Contudo, após 35 dias, seu diâmetro foi alterado significativamente, aumentando mais de 40 vezes em comparação ao valor inicial $(p<0,0001)$. Quando comparado ao valor de $\mathrm{DH}$ determinado após a preparação, as amostras estocadas a 4 e $37{ }^{\circ} \mathrm{C}$ mantiveram-se estáveis ao longo dos 42 dias, com variações não significativas, apesar de, após 42 dias, os valores médios de $\mathrm{DH}$, de ambas as amostras, terem aumentado (Figura 12).

Micelas com $5 \mu \mathrm{g} / \mathrm{mL}$ de AICIPc incorporado (Figura 12C), armazenadas em qualquer das temperaturas, tiveram diminuição significativa $(p<0,0001)$ dos valores médios de DH logo após 7 dias de estocagem. No entanto, em seguida as amostras a 4 e $25{ }^{\circ} \mathrm{C}$, mostraram um aumento significativo $(p<0,001)$ de $\mathrm{DH}$, mas ainda assim bem inferior ao determinado inicialmente. Esses valores médios de $\mathrm{DH}$ menores mantêm-se, significativamente, estáveis por 2 e 3 semanas, quando a 25 e $4{ }^{\circ} \mathrm{C}$, respectivamente. Este mesmo comportamento é observado nas amostras armazenadas a $37^{\circ} \mathrm{C}$, porém o ligeiro aumento do $\mathrm{DH}$ ocorre somente após 21 dias e manteve-se assim estável por 2 semanas. Após 42 dias, todas as amostras já se desestabilizaram com o aumento significativo $(p<0,0001)$ do $\mathrm{DH}$, quando comparado ao valor determinado logo após a preparação (Figura 12).

Já as micelas com $10 \mu \mathrm{g} / \mathrm{mL}$ de fotossensibilizante (Figura 12D), mantiveram o $\mathrm{DH}$ estável, por até 2 semanas, apenas quando estocadas a $25{ }^{\circ} \mathrm{C}$, quando comparado ao valor determinado inicialmente. Esta estabilidade foi somente de 1 semana para amostras estocadas a 4 e $37^{\circ} \mathrm{C}$. Após estes períodos, os valores médios de $\mathrm{DH}$ aumentaram significativamente $(p<0,0001)$ para amostras estocadas em todas as temperaturas.

De um modo geral, a temperatura de $\sim 25{ }^{\circ} \mathrm{C}$ foi a que melhor manteve os $\mathrm{DH}$ das formulações, ou seja, próximo ao observado logo após a preparação, por pelo menos uma semana, no máximo duas semanas (Figura 12). 
Na Figura 13 é mostrado a variação do Índice de Polidispersão (IPD) das micelas de Pluronic ${ }^{\circledR}$ F127 sem o fotossensibilizante (NP F127, Figura 13A) e com diferentes concentrações de Alumínio-Cloro-Ftalocianina (NP F127/AICIPc, Figuras 13B, C e D) armazenadas ao longo de 42 dias, nas temperaturas de $4, \sim 25$ e $37^{\circ} \mathrm{C}$. Os valores obtidos entre 42 e 63 dias não foram inseridos, pois para todas as amostras, sob as três diferentes temperaturas de armazenamento, o equipamento zetasizer apresentou valores que indicavam alta heterogenidade da amostra, inviabilizando uma apresentação gráfica adequada.
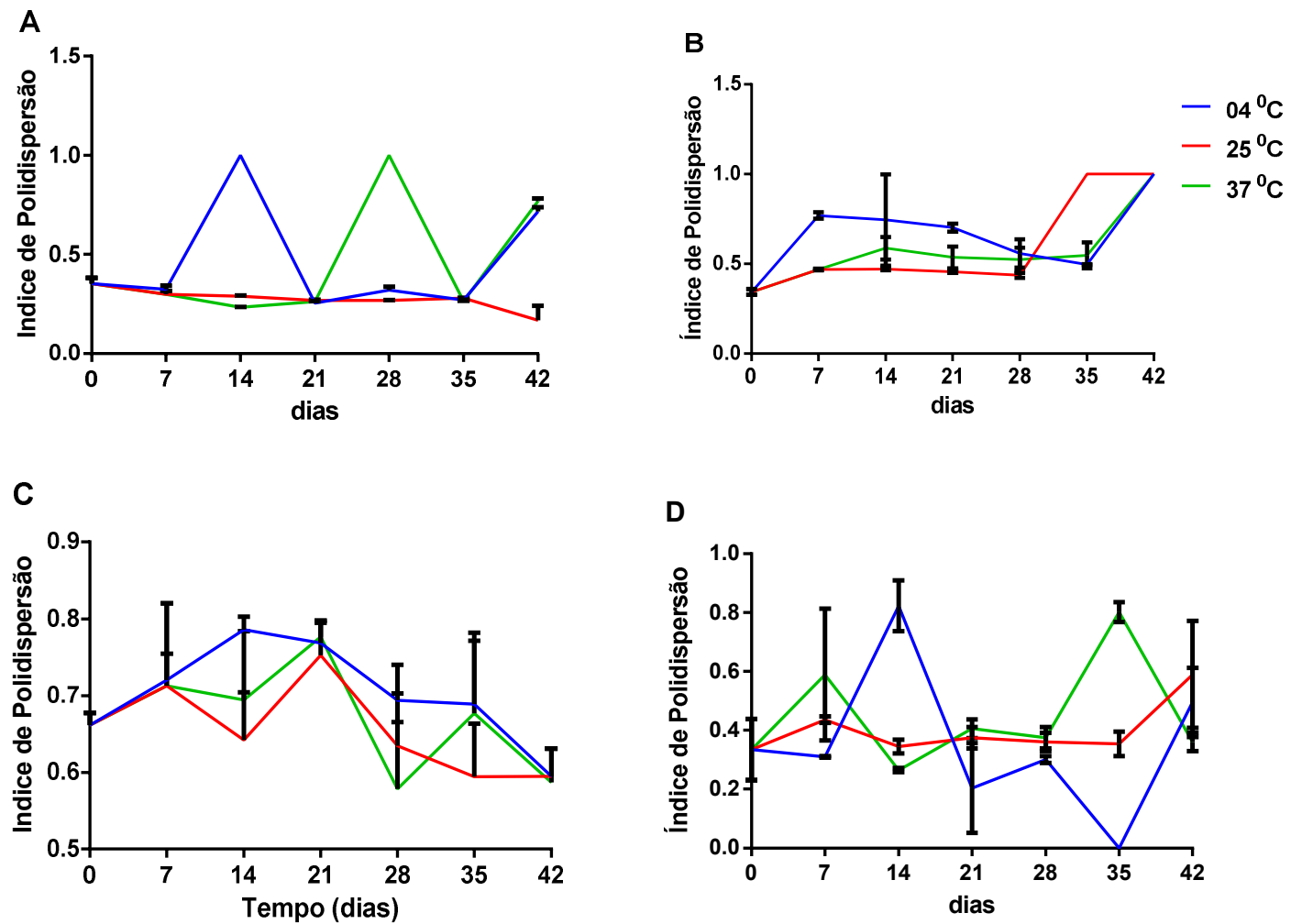

Figura 13. Variação do Índice de Polidispersão (IPD) por dispersão dinâmica de luz (DLS) das micelas de Pluronic ${ }^{\circledR} \mathrm{F} 127$, com ou sem fotossensibilizante armazenadas, sob as condições de $4{ }^{\circ} \mathrm{C}$ (linha azul), $\sim 25^{\circ} \mathrm{C}$ (linha vermelha) e $37^{\circ} \mathrm{C}$ (linha verde) ao longo de 42 dias. A - micelas sem fotossensibilizante (NP F127). B - micelas com $1 \mu \mathrm{g} / \mathrm{mL}$ de AICIPc. C - micelas com $5 \mu \mathrm{g} / \mathrm{mL}$ de AICIPc. D - micelas com 10 $\mu \mathrm{g} / \mathrm{mL}$ de AICIPc. Os dados estão representados como média \pm E.P.M. para triplicatas (AICIPc = Alumínio-Cloro-Ftalocianina). 
Observou-se que as amostras contendo micelas sem AICIPC (Figura 13A) mantiveram o índice de polidispersão (IPD) com variação não significativa até 21 e 35 dias, somente quando mantidas a $37 \mathrm{e} 25^{\circ} \mathrm{C}$, respectivamente, permanecendo como soluções monodispersas. A amostra armazenada a $4{ }^{\circ} \mathrm{C}$ mostrou-se estável apenas por 7 dias.

Amostra de micelas contendo $1 \mu \mathrm{g} / \mathrm{mL}$ de fotossensibilizante (Figura 13B) tornou-se significativamente $(p<0,001)$ polidispersa já com uma semana de armazenamento, quando mantida a $4{ }^{\circ} \mathrm{C}$, comparado ao valor inicial. Já as amostras mantidas a $\sim 25$ e $37{ }^{\circ} \mathrm{C}$ mantiveram-se monodispersas, com variações de IPD não significativas, por 28 e 35 dias de estocagem, respectivamente; comparadas com o valor determinado logo após a preparação.

Amostra de micelas contendo $5 \mu \mathrm{g} / \mathrm{mL}$ de AICIPc (Figura 13C) manteve, com variações não significativas, seu índice de polidispersão ao longo dos 42 dias, em todas as condições de temperatura de armazenamento. Para a amostra com 10 $\mu \mathrm{g} / \mathrm{mL}$ de fotossensibilizante (Figura 13D) incorporado nas micelas, o armazenamento a 4 e $37^{\circ} \mathrm{C}$, ao longo dos 42 dias, não teve variação significativa do IPD. No entanto, amostra mantida a $\sim 25{ }^{\circ} \mathrm{C}$ manteve-se monodispersa somente por uma semana, quando comparado ao IPD determinado no início.

De forma semelhante ao Diâmetro Hidrodinâmico (DH), a temperatura de $\sim 25^{\circ} \mathrm{C}$ foi a que melhor manteve os IPDs das formulações próximos ao observado logo após a preparação, por pelo menos uma semana.

$\mathrm{Na}$ Figura 14 é mostrada a variação do Potencial Zeta $(\mathrm{Pz})$ das micelas de Pluronic $^{\circledR}$ F127 sem o fotossensibilizante (NP F127, Figura 14A) e com diferentes concentrações de Alumínio-Cloro-Ftalocianina (NP F127/AICIPc, Figuras 14 B, C e D) armazenadas ao longo de 42 dias, nas temperaturas de $4, \sim 25$ e $37{ }^{\circ} \mathrm{C}$. A fim de manter o mesmo padrão de apresentação de dados de DH e IPD, os valores de Pz obtidos entre 42 e 63 dias não foram inseridos.

Observou-se na Figura 14 que ao longo dos 42 dias de armazenamento, nas três diferentes temperaturas, o Potencial Zeta $(\mathrm{Pz})$ das micelas sem o fotossensibilizante, com $1 \mu \mathrm{g} / \mathrm{mL}, 5 \mu \mathrm{g} / \mathrm{mL}$ e $10 \mu \mathrm{g} / \mathrm{mL}$ de AICIPc não teve variação significativa, mantendo-se, em boa parte do tempo, com carga negativa. 

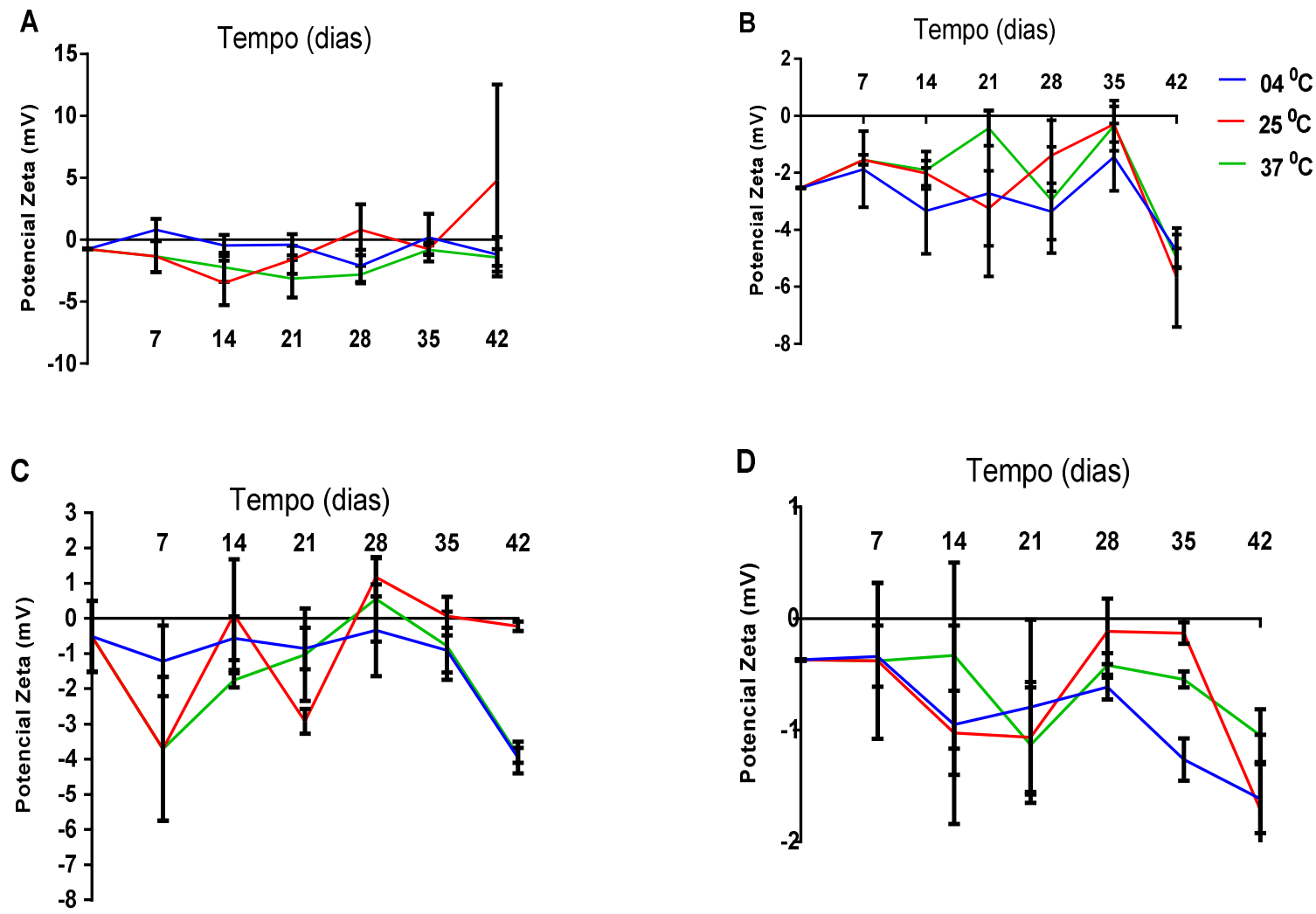

Figura 14. Variação do Potencial Zeta $(\mathrm{Pz})$ por dispersão de luz eletroforética das micelas de Pluronic ${ }^{\circledR}$ F127, com ou sem fotossensibilizante armazenadas, sob as condições de $4{ }^{\circ} \mathrm{C}$ (linha azul), $\sim 25^{\circ} \mathrm{C}$ (linha vermelha) e $37^{\circ} \mathrm{C}$ (linha verde) ao longo de 42 dias. A - micelas sem fotossensibilizante (NP F127). B - micelas com 1 $\mu \mathrm{g} / \mathrm{mL}$ de AICIPc. C - micelas com $5 \mu \mathrm{g} / \mathrm{mL}$ de AICIPC. D - micelas com $10 \mu \mathrm{g} / \mathrm{mL}$ de AICIPc. Os dados estão representados como média \pm E.P.M. para triplicatas (AICIPc = Alumínio Cloro Ftalocianina).

Quanto ao valor do potencial hidrogeniônico $(\mathrm{pH})$ das micelas de Pluronic ${ }^{\circledR} \mathrm{F} 127$ (Figura 15A,B,C) sem fotossensibilizante e com a menor concentração de AlumínioCloro-Ftalocianina $(1 \mu \mathrm{g} / \mathrm{mL})$ não foi observado nenhuma variação, permanecendo em 6 ao longo dos 63 dias, sob as três diferentes temperaturas de armazenamento. Já a formulação com $5 \mu \mathrm{g} / \mathrm{mL}$ de AICIPc, após uma semana de armazenamento em qualquer das temperaturas, teve o valor de $\mathrm{pH}$ medido em 6 , sendo que inicialmente este era de 7. As micelas de Pluronic ${ }^{\circledR} \mathrm{F} 127 \mathrm{com} 10 \mu \mathrm{g} / \mathrm{mL}$, que também apresentavam inicialmente um $\mathrm{pH}$ de 7 , passou a 6 após uma semana, apenas 
quando armazenada a $4{ }^{\circ} \mathrm{C}$ (Figuras A) e após duas semanas quando armazenadas a 25 (Figura B) e $37^{\circ} \mathrm{C}$ (Figura C). Apesar da ligeira acidificação das formulações com maior concentração de fotossensibilizante, elas ainda estavam dentro da neutralidade.
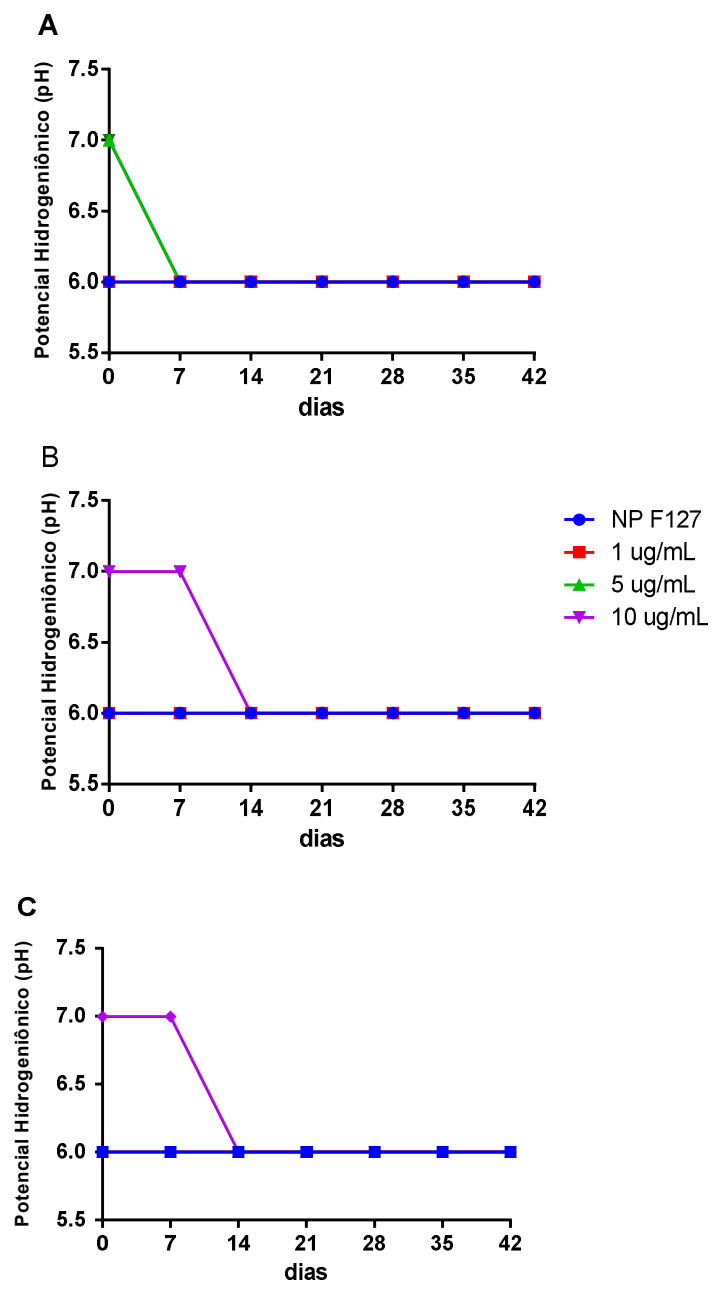

Figura 15. Variação do Potencial Hidrogeniônico $(\mathrm{pH})$ das micelas de Pluronic ${ }^{\circledR} \mathrm{F} 127$, com ou sem fotossensibilizante armazenadas, sob as condições de $4{ }^{\circ} \mathrm{C}(\mathbf{A}), \sim 25{ }^{\circ} \mathrm{C}$ (B) e $37^{\circ} \mathrm{C}$ (C) ao longo de 42 dias. Os dados estão representados como média \pm E.P.M. para triplicatas $(\mathrm{AICIPC}=$ Alumínio-Cloro-Ftalocianina $)$ e $(\mathrm{NP}$ F127 $=$ micela sem Alumínio-Cloro-Ftalocianina).

Diante dos resultados expostos acima, observou-se que, de um modo geral, as micelas de Pluronic $^{\circledR}$ F127 com diferentes concentrações de Alumínio-Cloro- 
Ftalocianina (NP F127/AICIPc) mantiveram uma melhor estabilidade coloidal quando armazenadas a temperatura ambiente $\left(\sim 25{ }^{\circ} \mathrm{C}\right)$ por até 14 dias. Assim, para os estudos in vitro, decidiu-se utilizar amostras que tenham sido armazenadas nesta condição até duas semanas após a sua preparação, quando então um novo lote de micelas era preparado.

\subsection{Caracterização fotofísica das micelas de Pluronic ${ }^{\circledR}$ F127 com Alumínio- Cloro-Ftalocianina (NP F127/AICIPc)}

A caracterização fotofísica por espectroscopia das micelas de Pluronic ${ }^{\circledR} F 127$ com $1 \mu \mathrm{g} / \mathrm{mL}$ de Alumínio-Cloro-Ftalocianina (NP F127/AICIPc), assim como das micelas sem o fotossensibilizante (NP F127) mostrou picos de absorção e de emissão de luz na região do comprimento de onda do vermelho. Na Figura 16A, observa-se o espectro de absorbância com um único pico de absorção a $670 \mathrm{~nm}$ para a formulação com fotossensibilizante incorporado na concentração de $1 \mu \mathrm{g} / \mathrm{mL}$, semelhante a uma amostra padrão de AICIPc. Na figura 16B, observa-se o espectro de emissão de fluorescência (excitação em $360 \mathrm{~nm}$ ) da NP F127/AICIPc com 1 $\mu \mathrm{g} / \mathrm{mL}$ de fotossensibilizante com um pico de fluorescência a $680 \mathrm{~nm}$, diferentemente das micelas sem fotossensibilizante (NP F127) que não apresentam pico de emissão. 

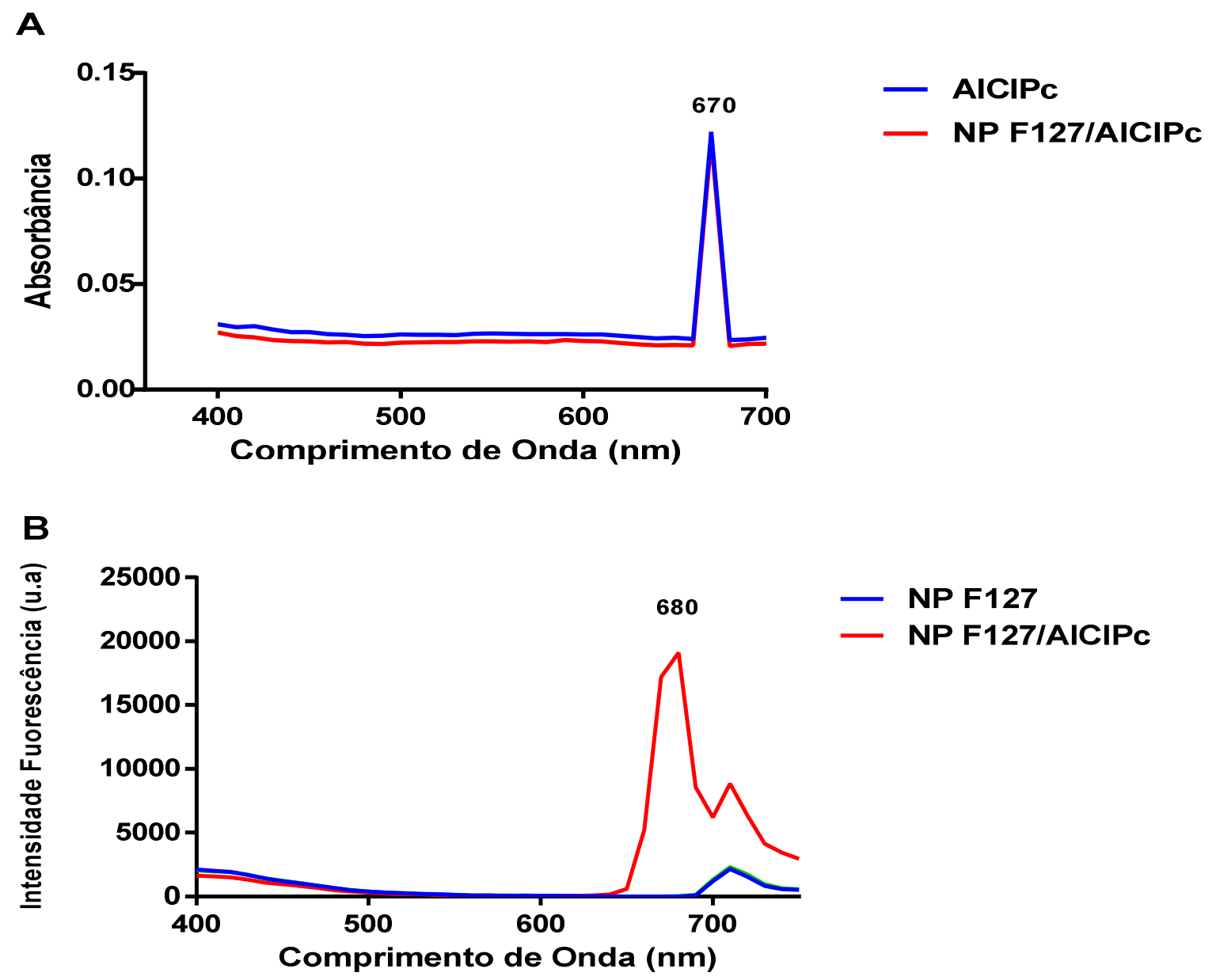

Figura 16. Espectro de absorção (A) e de emissão de fluorescência (B) com excitação a $360 \mathrm{~nm}$ de micelas de Pluronic ${ }^{\circledR} \mathrm{F} 127$ sem fotossensibilizante e com 1 $\mu \mathrm{g} / \mathrm{mL}$ de Alumínio-Cloro-Ftalocianina (NP F127/AICIPC), após a preparação. Em Apico único de absorção de $670 \mathrm{~nm}$ para a formulação com $1 \mu \mathrm{g} / \mathrm{mL}$ de AICIPc. Em B- pico de emissão de fluorescência a $680 \mathrm{~nm}$ para micelas de Pluronic $^{\circledR}$ F127 contendo $1 \mu \mathrm{g} / \mathrm{mL}$ de AICIPc e ausência de emissão de luz para Pluronic ${ }^{\circledR} \mathrm{F} 127 \mathrm{em}$ PBS.

4.4 Avaliação da Geração de Oxigênio Singleto pelas micelas de Pluronic ${ }^{\circledR}$ F127 com Alumínio-Cloro-Ftalocianina (NP F127/AICIPc) 
As micelas de Pluronic ${ }^{\circledR}$ F127 com diferentes concentrações de Alumínio-CloroFtalocianina (NP F127/AICIPc) foram capazes de gerar espécies reativas de oxigênio (ERO) segundo a técnica de decaimento do 1,3-difenil-isobenzofurano (DBF). Vale ressaltar que esta técnica é uma avaliação indireta da produção de ERO, pois é mensurada a absorbância que decai de forma diretamente proporcional à geração $\mathrm{de}^{1} \mathrm{O}_{2}$, e não a produção em si de ERO.

Observa-se na Figura 17 que há um decaimento da absorbância do DBF de forma mais acentuada para a formulação que contém a maior concentração de AICIPc incorporada nas micelas, quando comparada com as formulações que contêm as menores concentrações do fotossensibilizante, em relação ao tempo de exposição ao LED. Todas as concentrações de fotossensibilizante apresentaram produção de ERO significativa $(p<0,0001)$ tanto em relação ao início da exposição ao LED quanto em relação ao controle $(p<0,0001)$. Apenas as micelas sem AICIPc não apresentaram decaimento de absorbância significativa, o que demonstra que não houve produção de ERO.

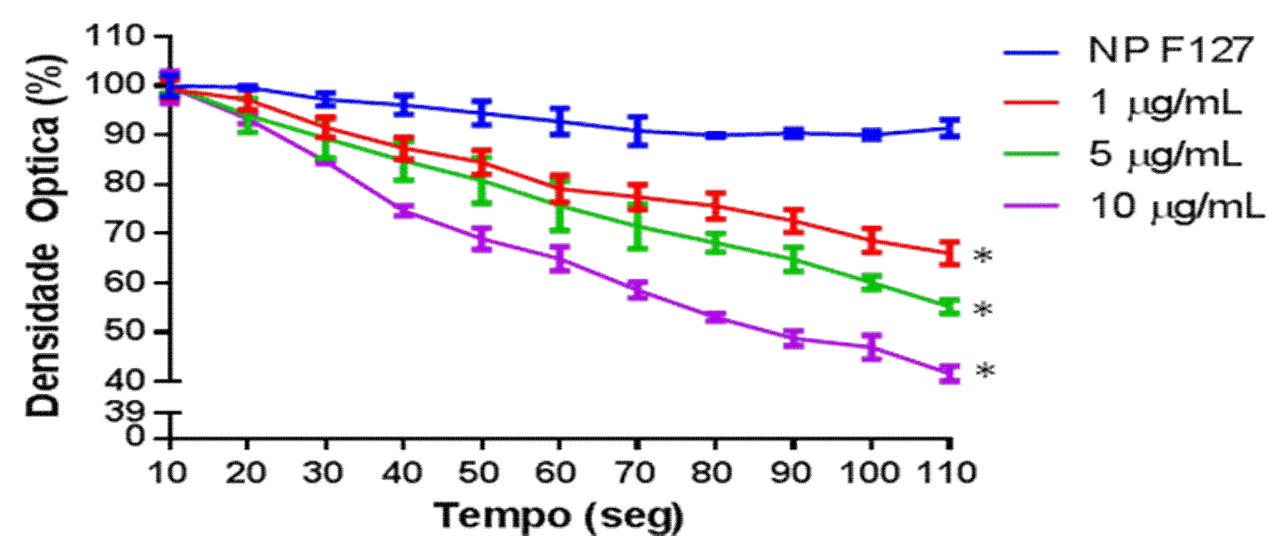

Figura 17. Valores percentuais da densidade óptica referente ao decaimento da absorbância do 1,3-difenil-isobenzofurano (DBF) em relação ao tempo de exposição ao LED de micelas de Pluronic $^{\circledR}$ F127 sem (NP F127) e com diferentes concentrações de Alumínio-Cloro-Ftalocianina (NP F127/AICIPc a 1, 5 e $10 \mu \mathrm{g} / \mathrm{mL}$ ). Os dados estão representados como média \pm E. P. M. para triplicatas. indica diferença estatística significativa com $p<0,0001$. 


\subsection{Determinação da toxicidade do LED na viabilidade celular}

Na Figura 18 é mostrado se a irradiação de luz LED, sem a presença de micelas de Pluronic ${ }^{\circledR}$ F127 com Alumínio-Cloro-Ftalocianina (NP F127/AICIPc) era capaz de induzir citotoxicidade e assim conduzir à morte tanto de células de melanoma (B16F10) quanto de melanoma modificado para expressar luciferase (B16F10FF).

Pode-se observar que não houve diferença estatisticamente significativa $(p>0,05)$ na viabilidade de ambos os tipos celulares, após 10 minutos de irradiação do LED, quando comparada com as células que não foram irradiadas.

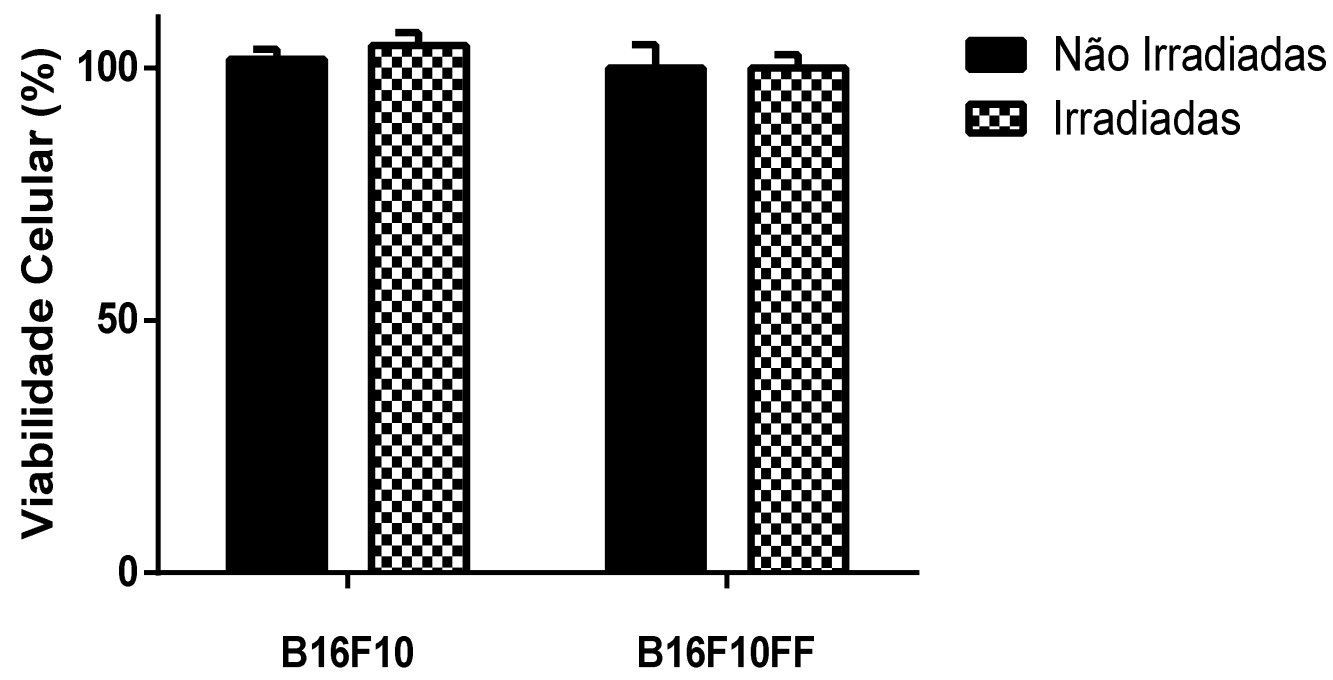

Figura 18. Viabilidade de células de melanoma murino (B16F10) e de melanoma modificada para expressar luciferase (B16F10FF) expostas ou não por 10 minutos de irradiação de diodo emissor de luz (LED) a $85,1 \mathrm{~J} / \mathrm{cm}^{2}$, avaliada posteriormente pelo método MTT. Os dados estão representados como média $\pm \mathrm{E}$. P. M. Foram realizados três experimentos em triplicata. Não houve diferenças estatisticamente significativas $(p>0,05)$.

4.6 Determinação da toxicidade das micelas de Pluronic ${ }^{\circledR}$ F127 com AlumínioCloro-Ftalocianina (NP F127/AICIPc) na viabilidade celular 
Na Figura 19 é mostrada se apenas as exposições de células de melanoma murino - B16F10 (Figura 19A) e melanoma murino modificada com FireFly Luciferase - B16F10FF (Figura 19B) às formulações de micelas de Pluronic ${ }^{\circledR}$ F127 com diferentes concentrações de Alumínio-Cloro-Ftalocianina (NP F127/AICIPc), ou às micelas de Pluronic ${ }^{\circledR}$ F127 sem o fotossensibilizante (NP F127) e ainda, apenas ao Alumínio-Cloro-Ftalocianina (AICIPc), por 15, 20 ou 25 minutos, sem qualquer irradiação da luz LED, para avaliar se eram capazes de induzir citotoxicidade e assim conduzir à morte destas células.

Observa-se na Figura 19A que apenas 73\% $(p<0,05)$ das células de melanoma murino (B16F10) permaneceram viáveis após 20 minutos de exposição a micelas de Pluronic $^{\circledR}$ F127 com $10 \mu \mathrm{g} / \mathrm{mL}$ de AICIPc, quando comparado com as células mantidas por 15, 20 e 25 minutos sem incubação com qualquer tipo de formulação (controle) e com a exposição por 20 minutos tanto de Alumínio-Cloro-Ftalocianina quanto de micelas sem AICIPc. As demais exposições não alteraram significativamente a viabilidade destas células, tanto comparado aos controles quanto entre as formulações, nos diferentes tempos estudados.

Em relação às células de melanoma murino modificada com FireFly Luciferase - B16F10FF (Figura 19B), verificou-se que não houve alteração significativa $(p>0,05)$ na viabilidade destas células em nenhuma das exposições às formulações, por qualquer dos tempos estudados, quando comparado aos controles (células não expostas) e entre as formulações. 

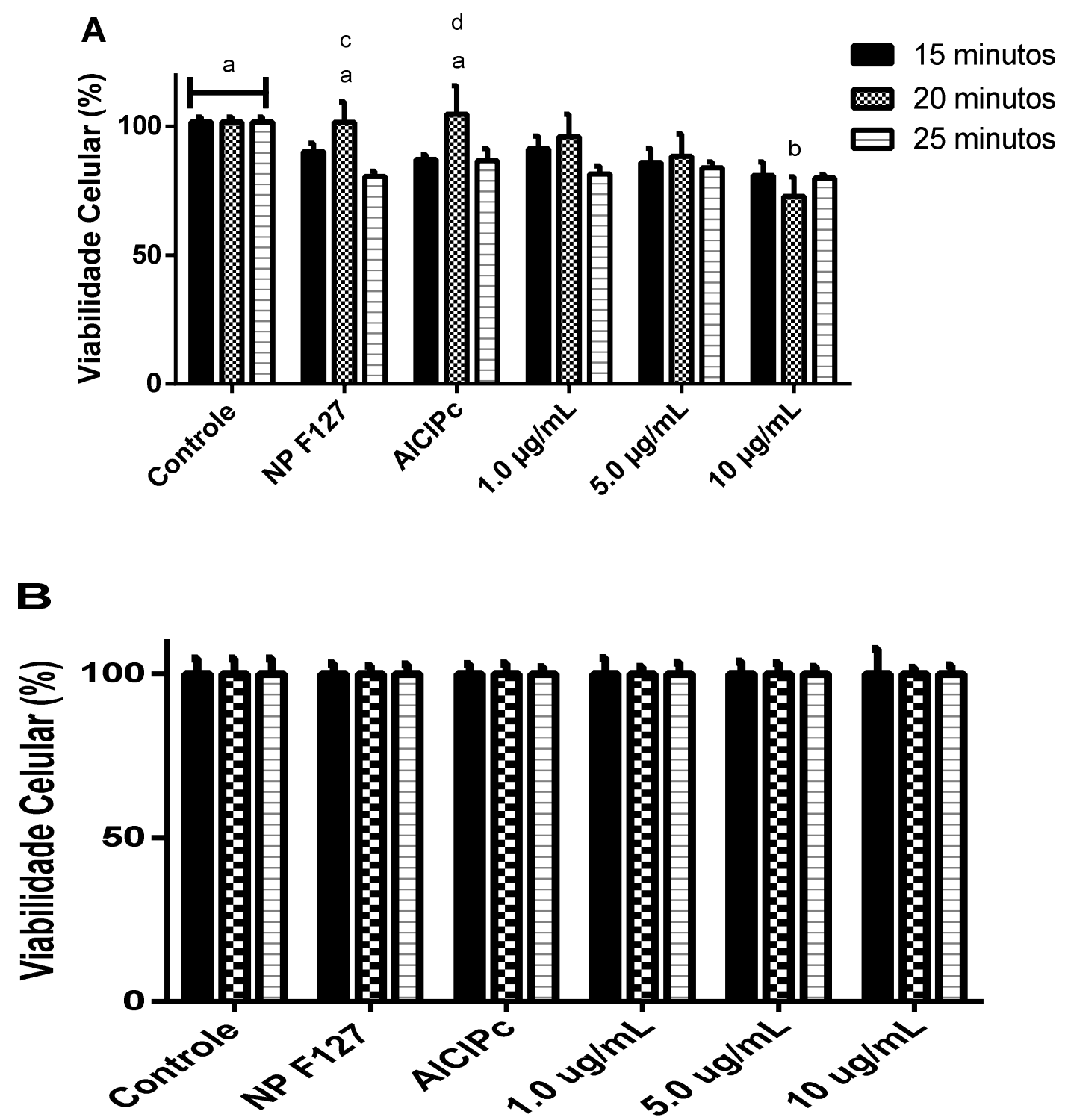

Figura 19. Viabilidade de células de melanoma murino, B16F10 (A) e de melanoma modificada para expressar luciferase, B16F10FF (B) expostas ou não (controle) às formulações de micelas de Pluronic $^{\circledR} \mathrm{F} 127$ com diferentes concentrações de Alumínio-Cloro-Ftalocianina (NP F127/AICIPc à 1, 5, $10 \mu \mathrm{g} / \mathrm{mL}$ ), ou às micelas de Pluronic ${ }^{\circledR}$ F127 sem o fotossensibilizante (NP F127) e ainda, apenas ao alumínioloro-ftalocianina (AICIPc), por 15, 20 ou 25 minutos, sem qualquer irradiação da luz LED, avaliada posteriormente pelo método MTT. Os dados estão representados como média $\pm \mathrm{E}$. P. M. Foram realizados três experimentos em triplicata. Letras diferentes significam diferenças estatisticamente significativas $(p<0,05)$. 


\subsection{Avaliação da Terapia Fotodinâmica mediada por micelas de Pluronic ${ }^{\circledR}$ F127 com Alumínio-Cloro-Ftalocianina (NP F127/AICIPc)}

Uma vez determinado que somente a irradiação do LED ou a exposição, por diferentes tempos, às formulações de micelas sem e com o fotossensibilizante, porém sem irradiação do LED, não causaram efeitos citotóxicos, de significância biológica, nas células B16F10 e B16F10FF, a terapia fotodinâmica mediada por micelas de Pluronic ${ }^{\circledR}$ F127 com Alumínio-Cloro-Ftalocianina (NP F127/AICIPc) foi avaliada.

Na Figura 20 é mostrado se as exposições de células B16F10 (Figura 20A) e B16F10FF (Figura 20B) às formulações de micelas de Pluronic ${ }^{\circledR}$ F127 com diferentes concentrações de Alumínio-Cloro-Ftalocianina (NP F127/AICIPC), ou às micelas de Pluronic ${ }^{\circledR}$ F127 sem o fotossensibilizante (NP F127) e ainda, apenas ao Alumínio-Cloro-Ftalocianina (AICIPc), por 15, 20 ou 25 minutos, e 10 minutos de irradiação da luz LED a $85,1 \mathrm{~J} / \mathrm{cm}^{2}$, eram capazes de induzir citotoxicidade e assim conduzir à morte destas células.

Observa-se na Figura 20A que houve uma diminuição significativa de $24 \%$ $(p<0,001)$, na viabilidade de células B16F10 após a exposição por 25 minutos à NP F127 sem o fotossensibilizante quando comparada aos controles.O fotossensibilizante (AICIPc) sozinho, também reduziu significativamente $(p<0,0001)$ a viabilidade destas células, independente do tempo de exposição, quando comparado aos controles, com redução da viabilidade entre 27 e $46 \%$. 

Amostra de micelas de Pluronic ${ }^{\circledR} \mathrm{F} 127$ com $1 \mu \mathrm{g} / \mathrm{mL}$ de AICIPc, independente do tempo de exposição, também reduziu significativamente $(p<0,0001)$ a viabilidade de B16F10 entre 47 e 65\%, quando comparado aos controles (Figura 20A). Porém, a análise comparativa desta formulação com o efeito citotóxico causado pelo fotossensibilizante sozinho $(\mathrm{AICIPC})$, mostrou uma diferença significativa $(p<0,05)$ na viabilidade celular somente na comparação da exposição das células por 15 minutos. Ou seja, nesta concentração de fotossensibilizante somente nos primeiros 15 minutos de exposição é que o AICIPc incorporado em micelas foi mais eficaz. A partir de 20 min de exposição o efeitos citotóxicos são iguais, mostrando que a citotoxicidade é dose-dependente.

Da mesma forma, amostra de micelas de Pluronic ${ }^{\circledR} \mathrm{F} 127 \mathrm{com} 5 \mu \mathrm{g} / \mathrm{mL}$ de AICIPc, independente do tempo de exposição, também reduziu significativamente $(p<0,0001)$ a viabilidade de B16F10 entre 62 e 69\%, quando comparado aos controles (figura 20A). Quando o efeito citotóxico desta formulação foi comparado com a exposição a AICIPC sozinho, independente do tempo de exposição, a viabilidade celular média diminui significativamente $(p<0,0001)$, de $67 \%$ (AICIPc) para 34\% (NP F127/AICIPc a $5 \mu \mathrm{g} / \mathrm{mL}$ ). No entanto, a comparação da citotoxicidade desta formulação com a de micelas contendo $1 \mu \mathrm{g} / \mathrm{mL}$ mostrou diferença significativa $(p<0,05)$ somente quando as células foram expostas por 25 minutos (viabilidade de $31 \%$ ) em relação a exposição por $20 \mathrm{~min}$ a NP F127/AICIPc a $1 \mu \mathrm{g} / \mathrm{mL}$ (viabilidade de $53 \%)$.

Células de B16F10 (Figura 20A) quando expostas tanto por 15, 20 ou 25 minutos a amostra de micelas de Pluronic ${ }^{\circledR} \mathrm{F} 127 \mathrm{com} 10 \mu \mathrm{g} / \mathrm{mL}$ de AICIPc tiveram sua viabilidade reduzida significativamente $(p<0,0001)$ entre 68 e $75 \%$, nos dois maiores tempos, quando comparado aos controles. Esta formulação foi significativamente $(p<0,0001)$ mais eficiente que o fotossensibilizante sozinho em qualquer dos tempos de exposição, tendo reduzido o percentual de células viáveis de 67 para 29\%. Quando o efeito citotóxico desta formulação foi comparado com a exposição a micelas de Pluronic $^{\circledR} \mathrm{F} 127 \mathrm{com} 1 \mu \mathrm{g} / \mathrm{mL}$ de AICIPc, houve significativamente $(p<0,05)$ mais morte do que das células, quando expostas a maior 
concentração de fotossensibilizante por 25 minutos quando comparado a exposição por 15 minutos a NP F127/AICIPc com $1 \mu \mathrm{g} / \mathrm{mL}$, a mesma significância foi observada na redução da viabilidade quando expostas por 20 minutos, porém a morte celular foi mais significativa $(p<0,001)$ quando as células foram expostas por 25 minutos a maior concentração do que por 20 minutos na concentração de $1 \mu \mathrm{g} / \mathrm{mL}$. Quando os efeitos citotóxicos das formulações NP F127/AICIPc a 5 e $10 \mu \mathrm{g} / \mathrm{mL}$ foram comparadas, não foi observada nenhuma diferença significativa $(p>0,05)$ na viabilidade destas células.

Em relação às células B16F10FF (Figura 20B), verificou-se que, comparado ao controle, não houve alteração significativa $(p>0,05)$ na viabilidade destas células quando expostas, independente do tempo à NP F127, fotossensibilizante e NP F127/AICIPc na dose de 1 e $5 \mu \mathrm{g} / \mathrm{mL}$. Também foi observado adiminuição na viabilidade celular quando expostas por 15 e 20 minutos a NP F127/AICIPc a 10 $\mu \mathrm{g} / \mathrm{mL}$. A viabilidade somente foi reduzida significativamente $(p<0,0001), 64 \%$, quando as células foram expostas, por 25 minutos, a maior concentração de AICIPC em micelas, comparado ao controle e aos demais grupos.

\subsection{Avaliação da eficácia de duas sessões de Terapia Fotodinâmica mediada por micelas de Pluronic $^{\circledR}$ F127 com Alumínio-Cloro-Ftalocianina (NP F127/AICIPc)}

Uma vez determinado que as células de melanoma murino modificadas com FireFly Luciferase (B16F10FF) não tinham a sua viabilidade celular alterada, significativamente, seja apenas pela irradiação do LED, pela exposição por diferentes tempos, às formulações de micelas sem e com o fotossensibilizante, com uma única sessão de TFD ou com as formulações mas sem irradiação do LED, uma nova abordagem terapêutica foi realizada, já que este era o tipo celular de interesse de uso em futuros estudos de diagnóstico de câncer por imagens de bioluminescência.

Assim, a terapia fotodinâmica mediada por micelas de Pluronic ${ }^{\circledR}$ F127 com Alumínio-Cloro-Ftalocianina (NP F127/AICIPC) em diferentes concentrações foi avaliada, em duas sessões, onde após 24 horas da primeira sessão de TFD, foi 
realizada uma segunda sessão afim de avaliar o comportamento e a viabilidade celular, uma vez que apenas uma sessão não foi suficiente para eliminar totalmente as células tumorais.

Na Figura 21 é mostrada se as exposições de células de melanoma murino modificada com FireFly Luciferase - B16F10FF (Figura 19) às formulações de micelas de Pluronic ${ }^{\circledR}$ F127 com diferentes concentrações de Alumínio-CloroFtalocianina (NP F127/AICIPc), ou às micelas de Pluronic ${ }^{\circledR}$ F127 sem o fotossensibilizante (NP F127) e ainda, apenas ao Alumínio-Cloro-Ftalocianina (AICIPC), por 15, 20 ou 25 minutos, e 10 minutos de irradiação da luz LED a 85,1 $\mathrm{J} / \mathrm{cm}^{2}$, seguida de uma nova exposição às diferentes formulações, pelos mesmos tempos, assim como uma segunda sessão de TFD, nas mesmas condições da anterior, com um intervalo de 24 horas entre elas, eram capazes de induzir uma maior citotoxicidade.

Observa-se na figura 21 que houve uma diminuição significativa, 44\% $(p<0,0001)$, na viabilidade de B16F10FF após a exposição por 20 e 25 minutos à NP F127 sem o fotossensibilizante, e de $17 \%(p<0,05)$ quando expostas por 15 , comparadas aos controles. De forma similar, o fotossensibilizante (AICIPC) sozinho, também reduziu significativamente $(p<0,0001)$ a viabilidade destas células, principalmente após 20 e 25 minutos de exposição, quando comparado aos controles, com redução da viabilidade de 65 e 58\%, respectivamente. Da mesma forma, a exposição por 15 minutos causou uma redução menor, apenas de 82,5\% $(p<0,05)$. Interessantemente, NP F127/AICIPc com as três diferentes concentrações de fotossensibilizante, independente do tempo de exposição, causaram a morte, de forma igualmente significativa ( $p<0,0001$ ), de 93,2 a 97,5\% das células, o que não foi observado com a aplicação de uma única TFD. 


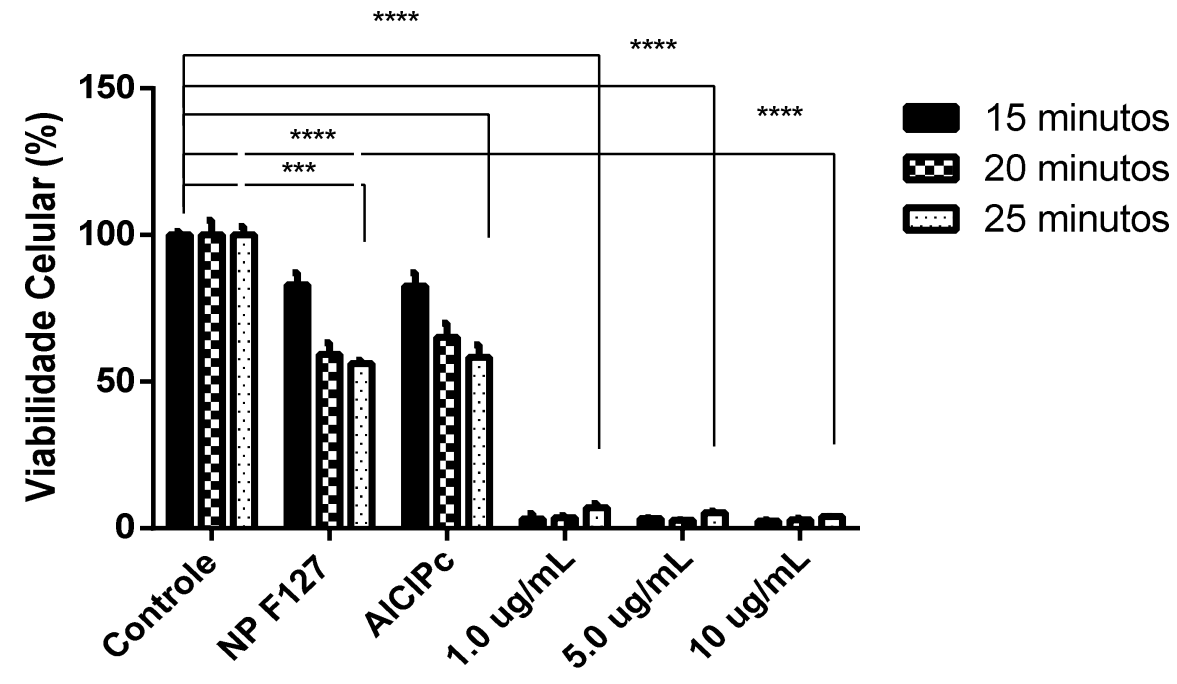

Figura 21. Viabilidade de células de melanoma murino modificadas para expressar luciferase, B16F10FF expostas ou não (controle) às formulações de micelas de Pluronic $^{\circledR}$ F127 com diferentes concentrações de Alumínio-Cloro-Ftalocianina (NP F127/AICIPC à $1,5,10 \mu \mathrm{g} / \mathrm{mL}$ ), ou às micelas de Pluronic ${ }^{\circledR} \mathrm{F} 127$ sem o fotossensibilizante (NP F127) e ainda, apenas ao Alumínio-Cloro-Ftalocianina (AICIPC), por 15, 20 ou 25 minutos, após irradiação por 10 minutos de diodo emissor de luz (LED) a $85,1 \mathrm{~J} / \mathrm{cm}^{2}$, seguida de uma nova exposição às diferentes formulações, pelos mesmos tempos, assim como uma segunda sessão de irradiação de LED, nas mesmas condições da anterior, com um intervalo de 24 horas entre elas, avaliada posteriormente pelo método MTT. Os dados estão representados como média \pm E. P. M. Foram realizados três experimentos em triplicata. * $=$ diferença estatística com $p<0,05 ;{ }^{* * *}=$ diferença estatística com $p<0,001 \mathrm{e}^{* * * *}=$ diferença estatística com $p<0,0001$.

4.9 Avaliação da eficácia de duas sessões de Terapia Fotodinâmica mediada por micelas de Pluronic $^{\circledR}$ F127 com Alumínio-Cloro-Ftalocianina (NP F127/AICIPc), analisando a dinâmica de proliferação celular. 
Para confirmar a eficácia do tratamento de melanoma murino de células transformadas para a expressão de luciferase (B16F10FF) com duas sessões de terapia fotodinâmica medicada por NP F127/AICIPc, a capacidade de proliferação destas células foi analisada, utilizou-se o sistema xCELLigence ${ }^{\mathrm{TM}}$ (Roche/ACEA). Vale ressaltar que este ensaio foi realizado somente com a exposição das células a NP F127/AICIPc $10 \mu \mathrm{g} / \mathrm{mL}$, por 25 minutos; e em duas sessões de TFD.

$\mathrm{Na}$ Figura 22 é mostrado se as exposições de células de melanoma murino modificada com FireFly Luciferase (B16F10FF) a micelas de Pluronic ${ }^{\circledR}$ F127 com 10 $\mu \mathrm{g} / \mathrm{mL}$ de Alumínio-Cloro-Ftalocianina (NP F127/AICIPc), por 25 minutos, e 10 minutos de irradiação da luz LED a $85,1 \mathrm{~J} / \mathrm{cm}^{2}$, seguida de uma nova exposição a mesma formulação e igual tempo de incubação, assim como uma segunda sessão de TFD, nas mesmas condições da anterior, com um intervalo de 24 horas entre elas, eram capazes de alterar a sua proliferação.

Observa-se na figura 22 que nas primeiras 24 horas as células proliferam igualmente em todos os poços conforme as células controle, pois em todos os poços só estão presentes as células, não houve exposição a NP F127/AICIPc e nem irradiação com LED. Passadas 24 horas, algumas células foram expostas por 25 minutos a $10 \mu \mathrm{g} / \mathrm{mL}$ NP F127/AICIPc e aplicada a primeira TFD - irradiadas, outras células foram apenas irradiadas pelo LED, sem o fotossensibilizante - controle irradiadas; outras células expostas ao AICIPc mas não irradiadas pelo LED - não irradiadas; e células sem exposição ao fotossensibilizante e também não irradiadas - controle não irradiada. Observa-se que logo após a aplicação da $1^{\text {a }}$ TFD, há uma maior diminuição do índice celular das células irradiadas, quando comparado ao controle não irradiada. Cerca de quatro horas após a TFD, estas células conseguem recuperar a sua capacidade proliferativa, tanto as células do controle não irradiadas quanto as células irradiadas, porém as irradiadas têm uma recuperação ligeiramente menor (não significativa $-p>0,05$ ) que o controle.

Na figura 22 também é mostrado que 24 horas após a $1^{\text {a }}$ TFD as diferenças nos índices celulares dos grupos são pequenas, não significativas ( $p>0,05)$. Uma nova exposição ao fotossensibilizante em micelas e a aplicação de uma segunda TFD causou um efeito similar ao da primeira aplicação da TFD, ou seja, uma queda 
no índice celular, principalmente das células expostas e irradiadas. Novamente, estas células recuperam a capacidade de proliferar, sendo que as células expostas e irradiadas aparentam uma recuperação menor, porém esta não difere significativamente $(p>0,05)$ do controle não irradiadas. Após 80 horas, as células do controle não expostas e nem irradiadas têm 0 índice celular reduzido significaticamente mais do que as demais células, pois as células entram em confluência mais rápido, o que causa um número maior de células mortas, quando comparado aos demais grupos, onde o método utilizado avalia qualitativamente.

O RTCA das células B16F10FF, gerou perfis de resposta celular dependente de tempo após o tratamento com TFD. A premeira sessão de TFD ocorreu 24 horas após o plaqueamento, onde pode-se observar o decaimento do IC, seguido de uma recuperação do crescimento. Na segunda sessão de TFD ocorreu 24 horas apósa premeira sessão de TFD, onde se observa novamente um decaimento do IC, também seguido de uma recuperação da proliferação celular.

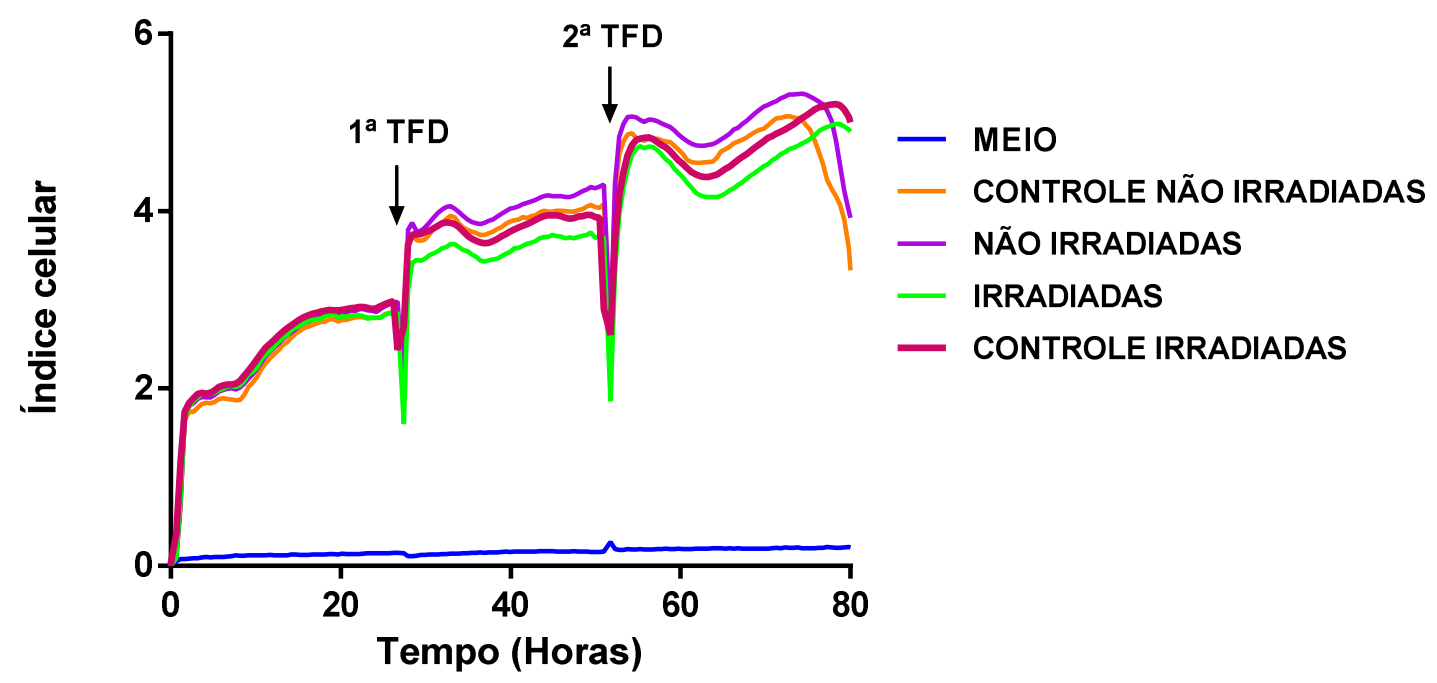

Figura 22. Avaliação de duas sessões de TFD com duas incubações de 25 minutos com micelas de NP F127/AICIPc $10 \mu \mathrm{g} / \mathrm{mL}$. A $1^{\text {a }}$ aplicação após 24 horas e a $2^{\mathrm{a}}$ após a primeira aplicação de TFD, ilustram o decaimento da proliferação celular nos grupos controle de células irradiadas e células irradiadas. e analisandos pela dinâmica de proliferação celular. 


\section{DISCUSSÃO}

A Organização Mundial de Saúde estima que, no ano de 2030, haverá 27 milhões de casos de câncer, 17 milhões de mortes por câncer. A cada ano,

globalmente, ocorrem cerca de 2,5 milhões de casos de câncer não-melanoma e aproximadamente 132.000 casos de melanoma. Em muitos países o melanoma é considerado um problema de saúde pública, sendo ele então responsável por 75$80 \%$ das mortes relacionadas ao câncer de pele (NCBI, 2015). Segundo estimativas de câncer no Brasil, foram previstos para 2014, 2.960 novos casos de melanoma em homens e 2.030 em mulheres (INCA, 2016). Para este mesmo ano, foi previstos aproximadamente, 76.100 novos casos nos Estados Unidos (NATIONAL CANCER INSTITUTE, 2015).

O melanoma cutâneo é um câncer de fácil detecção por ser facilmente visualizado. Quando um melanoma é detectado em seus estágios iniciais ele apresenta um bom prognóstico. Contudo, após o processo de progressão tumoral, gerando metástases, ele se torna um tumor de difícil tratamento (FIDLER, 2003). Sendo assim, apesar da sua baixa taxa de incidência, sua letalidade é elevada, pois a taxa de sobrevida de cinco anos dos pacientes com metástase em linfonodos varia de 13 a 69\% dos casos, dependendo da quantidade de linfonodos afetados. Quando há a metastização em outros órgãos, o tempo médio de sobrevida é estimado em oito meses, sendo que somente $10 \%$ dos pacientes sobrevivem mais de cinco anos após o diagnóstico (CHUDNOVSKY et al., 2005; GARBE et al., 2011; NATIONAL CANCER INSTITUTE, 2015; CANCER RESEARCH UK, 2015).

A terapêutica mantem-se de certa forma estacionária nos últimos 30 anos, baseando-se na terapia convencional química e/ou radiação, bem como na cirurgia (FARRELL, et al. 2011). A remoção cirúrgica de um tumor sólido e do tecido de margem de segurança é das opções eletivas para o tratamento quando a localização e o tamanho da neoplasia permitem a remoção cirúrgica do tumor. No entanto, este procedimento não elimina metastização e é ineficaz contra tumores não-sólidos. Adicionalmente, estudo de SHAPIRO \& FUNGMAN (1957) mostrou a ineficácia das 
terapias convencionais quando usadas individualmente, a multiterapia, ou seja, a combinação de ciclos de quimioterapia, radioterapia e imunoterapia (após cirurgia ou sem cirurgia), uma escolha assertiva (FENG et al., 2003; GU et al., 2007).

A nanotecnologia vem sendo utilizada como meio de diagnóstico ou terapêutica e, recentemente, com uma co-função de ambos. Como forma de tratamento, a nanotecnologia pode se valer de nanosistemas como as micelas poliméricas carreadoras de fotossensibilizantes para aplicação da terapia fotodinâmica (TFD) em patogenias como cânceres dos tipos: bucal, bexiga, pulmão, pele (primário e metastático do seio), intestino, trato digestivo superior, bexiga, dentre outros, assim como também na detecção e delineamento de lesões por fluorescência (MACHADO, 2000). Estes resultados correlacionam-se com diversos estudos anteriores que afirmam a importância da nanotecnologia no aumento da biodisponibilidade e farmacocinética de terapias oncológicas clássicas (FONSECA, et al. 2002; MANDAL, et al. 2009; YONCHEVA, et al. 2012; ZHANG, et al. 2013).

A proposta desse trabalho foi avaliar a utilização de micelas de Pluronic ${ }^{\circledR} \mathrm{F} 127$ para o carreamento de AICIPc, sendo o Pluronic ${ }^{\circledR}$ F127 um copolímero tri-bloco de poli(óxido de etileno) (PEO) e poli(óxido de propileno) (PPO), também chamado de polaxamer (Figura 07) (SCHMOLKA, 1972) com tamanho maior que $100 \mathrm{~nm}$ (TAILLEFER et al., 2000). O segmento PPO é relativamente hidrofóbico comparado aos segmentos de PEO circundantes. Graças à diferença de hidrofobicidade entre o PEO e o PPO, esse copolímero rapidamente configura-se em micelas quando em água, se a quantidade de polímero estiver acima da $\mathrm{CMC}$, que neste trabalho, foi de 0,15:3\% (peso/volume).

Devido ao estudo in vitro, que necessitava das micelas em um baixo grau de gelificação para que fosse possível o processo de internalização das mesmas pelas células tumorais B16F10 e B16F10FF em cultivo e, portanto, não possuem o mesmo sistema encontrado in vivo, foi utilizado nesse trabalho a CMC do Pluronic ${ }^{\circledR} \mathrm{F} 127$.

Em função de sua natureza, dificuldades técnicas são encontradas na caracterização físico-química das nanopartículas poliméricas. A caracterização das micelas engloba a avaliação da distribuição de tamanho das partículas (o diâmetro hidrodinâmico), do índice de polidispersão e a determinação do potencial zeta e do 
pH e, ainda, a avaliação da estabilidade em função do tempo e da temperatura de armazenamento (MAGENHEIM \& BENITA 1991; LEGRAND et al., 1999).

Neste trabalho, os valores médios do diâmetro hidrodinâmico (DH), encontrados ao longo do período de avaliação da estabilidade, foram maiores do que os determinados logo após a síntese, para a maioria das formulações armazenadas tanto a 4 quanto a $37^{\circ} \mathrm{C}$. As formulações mantidas a $25{ }^{\circ} \mathrm{C}$ tiveram este parâmetro mais conservado ao longo do tempo.

Os valores médios do diâmetro hidrodinâmico observados no período de 42 dias, indicam que o aumento nos tamanhos micelares observado quando as formulações foram armazenadas a $4^{\circ} \mathrm{C}$, foi acompanhada por um aumento da hidratação do núcleo micelar de AICIPc, segundo relata BASAK \& BANDYOPADHYAY (2013). Mas, o aumento da temperatura também provoca desidratação micelar pronunciada, de acordo com os achados de RAISING et al., (1984), pois a temperatura elevada promove a expulsão das moléculas de água da rede de polímeros, que mudam a sua configuração espacial podendo deixar a micela com DH aumentado. Isso acontece com todos os Pluronics, já que a agregação de F127 está igual e fortemente influenciada pela temperatura (PRASAD et al., 1979; TURRO \& CHUNG, 1984; RASSING \& MCKENNA, 1984; WANKA et al., 1994; HOLLAND et al., 1995; CHU \& ZHOU, 1996;). Portanto, o ocorrido na avaliação da estabilidade para as micelas de NP F127/AICIPc está dentro do esperado. Outro fator que pode estar ocasionando o aumento do $\mathrm{DH}$ é um provável aprisionamento de moléculas de água pelas cadeias poliméricas, a partir das ligações de hidrogênio com as correntes de poli (oxietileno) (SCHERLUND et al., 2000; LIN \& ALEXANDRIDIS, 2002; FOSTER \& COSGROVE, 2009).

Vale ressaltar que um fenômeno interessante acontece com vários copolímeros de polioxietileno. Eles apresentam o chamado "cloud point" ou "clouding temperature" ("ponto de turvação" ou "temperatura de nuvem"). O "cloud point" ocorre à medida que a temperatura do sistema aumenta, sua solubilidade em água diminui devido à quebra das ligações de hidrogênio entre o polioxietileno e a água, e o sistema começa a formar uma segunda fase que lhe confere turbidez; a 
temperatura a partir da qual o sistema forma essa nova fase faz com que as propriedades do surfactante possam ser perdidas a partir de então (MYERS, 1992).

Em relação ao índice de polidispersão (IPD), nas três temperaturas de armazenamento, a avaliação da estabilidade das formulações mostrou que os valores de IPD aumentam conforme a concentração do fotossensibilizante AICIPc aumenta também, a exceção da formulação NP F127 $10 \mu \mathrm{g} / \mathrm{mL}$, que apresentou valores quase idênticos nas três temperaturas, sendo que estes valores são menores do que os das NP F127 $1 \mu \mathrm{g} / \mathrm{mL}$ e NP F127 $5 \mu \mathrm{g} / \mathrm{mL}$. A temperatura que teve um melhor IPD foi a de $\sim 25{ }^{\circ} \mathrm{C}$. Porém, pelos valores apresentados, todas as formulações em todas as temperaturas, apresentaram-se polidispersas ou tendendo à polidispersão (ANTON \& VANDAME, 2009; SOLÈ et al., 2012; FRYD \& MASON, 2012).

Outro parâmetro igualmente importante na avaliação da estabilidade é o potencial zeta $(\mathrm{Pz})$, que reflete o potencial de superfície das partículas. O Pz é influenciado pelas mudanças na interface com o meio dispersante, em razão da dissociação de grupos funcionais na superfície da partícula ou da adsorção de espécies iônicas presentes no meio aquoso de dispersão (MAGENHEIM \& BENITA 1991; MOSQUEIRA et al., 2000). Os valores encontrados neste trabalho, ao longo do período de avaliação da estabilidade, mostram que as micelas com o fotossensibilizante, em diferentes concentrações, permanecem com uma carga de superfície resultante ainda negativa, tendendo a neutra, como quando recémpreparadas, independente da temperatura de armazenamento.

Os poloxameros, os tensoativos não-iônicos, como o Pluronic $F 127^{\circledR}$, tendem a reduzir o valor absoluto deste parâmetro (LEGRAND et al., 1999). Em módulo, um valor de potencial zeta relativamente alto é importante para uma boa estabilidade físico-química da suspensão coloidal, pois grandes forças repulsivas tendem a evitar a agregação em função das colisões ocasionais de nanopartículas adjacentes (SCHAFFAZICK et al., 2003). Os resultados apresentados para o potencial zeta (Figura 8A, B,C,D) demonsmostram que a NP F127/AICIPC apresentou uma superfície relativamente neutra, mesmo com a adição de alumínio-cloro-ftalocianina, que é considerada levemente positiva. Os valores do potencial zeta, se comparados 
com a NP F127 sem AICIPc, apresentaram pouca variação quanto a sua carga. Isso demonstra que esse sistema não tem muita estabilidade, mas em contrapartida, possui uma ótima atividade biológica.

Em estudo sobre carga de nanopartículas foi demonstrado que partículas com um potencial entre $-30 \mathrm{mV}$ e $+30 \mathrm{mV}$ são mais estáveis em suspensão e apresentam menor agregação, assim como também foi demonstrado que partículas neutras apresentam menor taxa de opsonização se comparadas às partículas altamente carregadas (SWAMI et al., 2012). Estes dados foram confirmados por um estudo de XIAO et al., (2011) que avaliou o efeito de partículas com o mesmo tamanho, mas cargas diferentes, quando incubadas com macrófagos de rato. Os autores mostraram que partículas com um potencial muito negativo ou muito positivo eram facilmente internalizadas pelos macrófagos (XIAO et al., 2011).

Portanto, as partículas devem apresentar uma superfície neutra ou relativamente negativa, para não interagir com o sistema imunitário ou com proteínas do soro, garantindo uma atividade biológica máxima (AGGARWAL et al. 2009).

Os valores de $\mathrm{pH}$ encontrados nas formulações de NP F127/AICIPc apresentaram uma basicidade (ph 7) para a F127/AICIPC $10 \mu \mathrm{g} / \mathrm{mL}$ a $\sim 25{ }^{\circ} \mathrm{C}$, na leitura inicial (logo após o preparo) que permaneceu até o sétimo dia, a partir de então, todas as concentrações da F127/AICIPc, em todas as três temperaturas avaliadas, apresentaram $\mathrm{pH}$ igual a seis, que permaneceu ao longo de todo o período de avalialção da estabilidade, indicando que nem o polímero utilizado, nem o alumínio-cloro-ftalocianina, alteraram esse parâmetro.

No trabalho realizado por Calvo e colaboradores (1992) foi observada a alteração do $\mathrm{pH}$, que pode ser um indício de degradação do polímero e que em suspensões de nanocápsulas e de nanoesferas, após seis meses de armazenamento, ocorre a diminuição do pH destas formulações (CALVO et al., 1992).

No presente estudo, os espectros de absorção e de emissão de fluorescência encontram-se na faixa do visível de 650-700 nm (EDWARDS \& GOUTERMAN, 1970), característicos das ftalocianinas em etanol, no estado não agregado (RICO et al., 2013). Tem sido relatado que, ao utilizar solventes com polaridade mais elevada, 
observou-se o deslocamento das bandas de emissão deslocam-se no espectro de absorção (RAUF et al., 2012), mas isto não ocorreu em nosso trabalho, mesmo sendo o fotossensibilizante alumínio-cloro-ftalocianina solubilizado em etanol, pois as concentrações do fotossensibilizante utilizadas foram baixas (POZO-INSFRAN et al., 2004).

Segundo a técnica de decaimento do 1,3-difenil-isobenzofurano (DBF), ocorreu um decaimento da absorbância do DBF de forma mais acentuada para a formulação que contem a maior concentração de AICIPc incorporada nas micelas, quando comparada com as formulações que contêm as menores concentrações do fotossensibilizante, em relação ao tempo de exposição ao LED. Todas as concentrações de fotossensibilizante utilizadas apresentaram produção de ERO significativa tanto em relação ao início da exposição ao LED quanto em relação ao controle, as micelas sem AICIPc, que não apresentou decaimento de absorbância significativa (Figura 15).

A capacidade de geração de ERO pela alumínio-cloro-ftalocianina juntamente com o perfil de absorção e emissão mostram que as amostras da NP F127/AICPc testadas apresentam propriedades fotofísicas ideais para seu uso como mediador da TFD no tratamento de células neoplásicas.

O Melanoma é um tipo de tumor que favorece a aplicação de TFD utilizando o fotossensibilizador alumínio-cloro-ftalocianina (AICIPc). O alumínio-cloro-ftalocianina é um fotossensibilizante hidrofóbico que atua principalmente na organela mitocôndria. Por ter atividade nesta organela, KESSEL \& LUO (1998) demonstraram que o fotossensibilizante AICIPc é um rápido indutor de apoptose, contrastando assim, com outros fotossensibilizantes que agem nos lisossomos ou na membrana plasmática.

A toxicidade das formulações NP F127/AICIPc foi averiguada por meio do ensaio de MTT, para as linhagens celularesde melanoma murino e melanoma murino modificada com FireFly Luciferase. A determinação da toxicidade do LED na viabilidade celular mostrou que não houve diferença na viabilidade de ambos os tipos celulares, após 10 minutos de irradiação do LED, quando comparada com as células que não foram irradiadas. Estudos prévios que indicam que as matrizes das 
nanopartículas (principalmente os poloxâmeros) são mais tóxicas para células normais do que para células tumorais como as células B16 F10 e B16F10FF (WEI et al. 2009).

As células B16F10 e B16F10FF expostas às micelas com diferentes concentrações de alumínio-cloro-ftalocianina (NP F127/AICIPc), ou às micelas sem o fotossensibilizante (NP F127) e ainda, apenas a lumínio-cloro-ftalocianina (AICIPC), por 15, 20 ou 25 minutos, sem qualquer irradiação da luz LED, mostrou que apenas 73\% das células B16F10 permaneceram viáveis após 20 minutos de exposição. Verificou-se também que não houve alteração na viabilidade das células B16F10FF em nenhuma das exposições às formulações, por qualquer dos tempos estudados, quando comparado às células não expostas.

A TFD com micelas com concentração de $1 \mu \mathrm{g} / \mathrm{mL}$ de fotossensibilizante, independente do tempo de exposição, reduziu significativamente a viabilidade de B16F10 entre 47 e 65\%, em relação ao controle, sendo mais eficaz no tempo de incubação de 15 minutos e com $5 \mu \mathrm{g} / \mathrm{mL}$ de AICIPC, independente do tempo de exposição, a micela também reduziu significativamente a viabilidade de B16F10 entre 62 e 69\%, quando comparadas ao controle sem TFD. A viabilidade somente foi reduzida significativamente a 64\%, quando as células foram expostas, por 25 minutos, a maior concentração de AICIPc em micelas, comparado ao controle e aos demais grupos.

Células B16F10FF tratadas com duas TFD e duas exposições a NP F127/AICIPC, apresentaram para as três diferentes concentrações de fotossensibilizante, independente do tempo de exposição, morte celular de 93,2 a $97,5 \%$ o que não foi observado com a aplicação de uma única terapia.

Contudo, as células de melanoma murino (B16F10) demonstraram ser mais sensíveis à TFD com micelas (NP F127/AICIPC) em todas as concentrações se comparada a célula B16F10FF, que apresentou uma pequena porcentagem de morte celular apenas para a NP F127 $10 \mu \mathrm{g} / \mathrm{mL}$, em todos os tempos de incubação aplicados.

A terapia fotodinâmica que utiliza altas concentrações de fotossensibilizantes e valores de fluência que permitem a viabilidade de $10 \%$ das células tumorais tratadas, 
são consideradas como terapias de altas doses (PIETTE et al., 2003). O resultado deste trabalho nos mostrou exatamente isso: a viabilidade das células B16F10próximo de 15\%, para as células B16F10FF com viabilidade de $7 \%$, ambas tratadas com duas aplicações de TFD.

Contudo, vale ressalta que o melanoma aqui tratado contém um alto conteúdo de melanina, sendo esse um fator que complica o tratamento com TFD, visto que, o sistema é fotoativado em um comprimento de onda dentro da faixa de absorção da melanina (LANGMACK et al.,2001). Assim, a habilidade da luz em penetrar o tumor para ativar a NP F127/AICIPc pode ter sido parcialmente diminuída devido ao alto conteúdo de melanina presente das células B16F10 e B16F10FF. Além disso, a melanina possui um efeito antioxidante (DAVIDS e KLEEMAN, 2011) que atua como mais um mecanismo de resistência à TFD. Ciente deste fator complicador, foi importante ter realizado os experimentos nestes modelos de melanoma, considerando que a maioria dos melanomas são melanóticos, contendo diferentes graus e tipos de melanina e pigmentação (BECHET et al., 2008; CAMERIN et al., 2010; KANO et al., 2013; MASTER et al., 2012)

O fato das células B16F10FF terem um grande percentual de morte após uma segunda aplicação de TFD, contrapõe-se aos estudos de VARRIALE et al., 2002, que ralata a eficiência da TFD em uma única aplicação. Na maioria dos estudos descritos na literatura, não foi relatado dados correspondentes a duas terapias fotodinâmicas aplicadas em células modificadas com FireFly Luciferase.

Em trabalhos em que se utilizaram valores de fluência semelhantes com TFD mediada por outros FS foram observarados resultados parecidos em células de melanoma B16F10 (CARVALHO, 2013; PIETTE et al., 2003). Um estudo realizado por ZHAO e colaboradores (2009), onde foram utilizado várias concentrações de silicone ftalocianina (Pc4) livre e encapsulada em partículas de sílica, que foram aplicadas e posteriormente irradiadas na fluência de $22,5 \mathrm{~J} / \mathrm{cm}^{2}$, mostrou uma viabilidade celular de aproximadamente $20 \%$. Alguns trabalhos com fluências menores (MADURAY et al., 2011) veicularam tetra-sulfoftalocianinas de alumínio para o tratamento de células de fibroblastos e melanoma. A fluência de $4,5 \mathrm{~J} / \mathrm{cm}^{2}$ mostrou viabilidade de $48 \%$ para as células de melanoma e $78 \%$ para os 
fibroblastos. Para os resultados apresentados, foi possível observar que a toxicidade nas células tumorais foi um evento dependente tanto da concentração de FS utilizado quanto da dose de energia aplicada, o que está de acordo com a literatura (KOLAROVA et al., 2007; KASTLE et al., 2011).

Os reultados apresentados do RTCA indicam que quando foi aplicada a primeira TFD, ocorreu um decaimento do índice celular, seguido de uma recuperação das células. Quando foi aplicada a segunda terapia fotodinâmica, novamente, ocorreu um de caimento do índice. As células que não foram expostas à NP F127/AICIPc, tiveram sua morte ocasionada por confluência, enquanto as células que receberam a TFD, tiveram uma recuperação seguida do decaimento do índice celular.

A metodologia desse ensaio utiliza a impedância, que é uma medida da total oposição ao fluxo de corrente elétrica em um circuito de corrente alternada, feita por dois componentes: resistência óhmica e reactância. A Utilização da impedância para uma leitura celular foi descrita por GIAEVER \& KEESE, em 1993. Contudo, mais dados precisam ser gerados com um grande conjunto de compostos para provar a boa correlação entre medidas celulares de impedância e parâmetros de toxicidade clássicos (ATIENZAR et al., 2011).

O RTCA foi usado para reunir informações sobre diferentes processos celulares, incluindo a proliferação celular e a citotoxicidade da NP F127/AICIPc (ABASSI et al., 2009), como no trabalho de FRANKE et al., 2010, que observou a análise realizada em tempo real (RTCA), em células de melanoma tratadas com N69 (fator indutor de apoptose), foi utilizado para indicar os efeitos da citosina-ferro contendo análogos N69 e avaliar o envolvimento da caspase na rota do processo de apoptose. Os resultados do RTCA revelaram uma diminuição dependente da dose de N69 e da densidade celular.

Nesse estudo observou-se que a NP F127 ALCIPc in vitro é capaz de causar morte celular nas células B16F10, enquanto as células B16F10FF, mostraram-se mais resistentes à TFD. Por isso, foi nescessária a repetição da TFD com nova exposição às micelas de ALCIPc para que houvese uma diminuição da viabilidade celular. Os efeitos da NP F127 ALCIPc nas células B16F10FF, com duas exposições 
às micelas e duas aplicações de TFD, levaram ao aumento da citotoxicidade que foi de $7 \%$.

Os estudos in vitro foram utilizados para guiar o estabelecimento de uma nova terapêutica antes da realização de estudos de toxicologia in vivo (MACDONALD \& ROBERTSON, 2009) e proporcionaram informações relevantes sobre a potencial toxicidade das formulações empregadas.

\section{CONCLUSÃO}

- Os resultados da caracterização das amostras mostraram que: 1) nas maiores concentrações de AICIPc incorporada às micelas foi observado um aumento significativo no diâmetro hidrodinâmico $(\mathrm{DH})$, quando comparado com as micelas sem o fotossensibilizante; 2) a temperatura de $25{ }^{\circ} \mathrm{C}$ foi a que melhor manteve os DH das formulações por pelo menos uma semana, no máximo duas semanas; 3 ) as amostras mantidas a $\sim 25$ e $37^{\circ} \mathrm{C}$ mantiveram-se monodispersas, com variações de IPD não significativas por 28 a 35 dias de estocagem, ao longo de 42 dias de armazenamento, 4) o Potencial zeta das micelas sem o fotossensibilizante e com as diferentes concentrações de AICIPc manteve-se, em boa parte do tempo, com carga negativa.

- Portanto, os resultados indicaram que, a temperatura de $\sim 25^{\circ} \mathrm{C}$ escolhida para a execução dos ensaios in vitro, foi a que melhor manteve os parâmetros ao longo do tempo de avaliação. porém ajustes na formulação são nescessários para que haja uma maior estabilidade do sistema.

- Quanto ao valor do potencial hidrogeniônico $(\mathrm{pH})$ das micelas de Pluronic ${ }^{\circledR} \mathrm{F} 127$, apesar de uma ligeira acidificação das formulações com maior concentração de fotossensibilizante, elas estavam dentro da neutralidade. Uma vez que a literatura descreve que nanopartículas com pH levemente ácidas, quase neutras, são ideiais para o uso in vivo. 
- A mímina concentração de polímero para que ocorra a formação de micelas (CMC) foi útil para os estudos in vitro. Porém, altera os parâmetros responsáveis por uma melhor estabilidade do sistema. Para possíveis estudos in vivo, a CMC ideal deve ser utilizada no preparo das formulações da NP F127/AICIPc, ou seja, uma maior quantidade de polímero F127 dará ao sistema de micelas um maior grau de gelificação e consequentemente, uma maior estabilidade e um possível uso por via tópica.

- A caracterização fotofísica por espectroscopia das micelas de Pluronic ${ }^{\circledR}$ mostrou picos de absorção e de emissão de luz na região do comprimento de onda do vermelho. Foi observado que o espectro de absorbância apresentou um pico de absorção a $670 \mathrm{~nm}$ para a formulação com fotossensibilizante. Também foi observado o espectro de emissão de fluorescência (excitação em $360 \mathrm{~nm}$ ) da NP F127/AICIPc com um pico de fluorescência a $680 \mathrm{~nm}$, diferentemente das micelas sem fotossensibilizante (NP F127) que não apresentam pico de emissão. Os resultados estão de acordo com a descrição da literatura para a alumínio-cloroftalocianina.

- As micelas de Pluronic ${ }^{\circledR}$ F127 com diferentes concentrações de a-cloro-ftalocianina (NP F127/AICIPc) foram capazes de gerar espécies reativas de oxigênio (ERO) segundo a técnica de decaimento do 1,3-difenil-isobenzofurano (DBF). Todas as concentrações de fotossensibilizante apresentaram produção de ERO significativa $(p<0,0001)$ tanto em relação ao início da exposição ao LED quanto em relação ao controle $(p<0,0001)$.

- A determinação da toxicidade do LED na viabilidade celular mostrou que a TFD não foi capaz de induzir citotoxicidade e conduzir à morte tanto de células de melanoma (B16F10) quanto de melanoma modificado para expressar luciferase (B16F10FF).

- A determinação da toxicidade das micelas com $10 \mu \mathrm{g} / \mathrm{mL}$ de AICIPc, , mostrou que apenas $73 \%$ das células de melanoma murino (B16F10) permaneceram viáveis após 20 minutos de exposição. 
- Em relação às células de melanoma murino modificada com FireFly Luciferase ( B16F10FF), verificou-se que não houve alteração significativa na viabilidade destas células em nenhuma das exposições às formulações, por qualquer dos tempos estudados, quando comparado aos controles (células não expostas) e entre as formulações sem aplicação da TFD.

- As células B16F10, após a TFD mediada por micelas de Pluronic ${ }^{\circledR}$ F127 com Alumínio-Cloro-Ftalocianina (NP F127/AICIPc), apresentaram dinminuição da viabilidade celular por dose dependente, com redução da viabilidade entre 27 e 46\%. independente do tempo de exposição, quando comparado aos controles.

- As células B16F10FF, após a TFD mediada por micelas de Pluronic ${ }^{\circledR}$ F127 com Alumínio-Cloro-Ftalocianina (NP F127/AICIPc), demonstrou que a viabilidade somente foi reduzida a $64 \%$, quando as células foram expostas, por 25 minutos, a maior concentração de AICIPc em micelas, comparado ao controle e aos demais grupos, diferentemente das células B16F10.

- Interessantemente, a NP F127/AICIPc com as três diferentes concentrações de fotossensibilizante, após duas aplicações da TFD, nas células B16F10FF, independente do tempo de exposição, causaram a morte de 93,2 a $97,5 \%$ das células, o que não foi observado com a aplicação de uma única TFD, para a mesma linhagem celular.

- Células modificadas com FireFly Luciferase (B16F10FF) apresentam um padrão que difere das células B16F10. Alguns estudos relacionados à biologia molecular dessa linhagem poderiam esclarecer certas questões como a possibilidade da TFD interferir ou não na expressão da bioluminescência, e/ou possíveis diferenças relacionadas ao processo de modificação para expressão de luciferase.

- Os resultados apontam que a TFD mostra-se mais eficiente em células de melanoma murino do que em células de melanoma moficadas. Esses resultados mostram uma maior sensibilidade das células tumorais B16F10, talvez por produzirem uma menor quantidade de melanina. Esse fator permanece obscuro e deve ser explorado a fim de orientar uma nova e melhor terapêutica. 
- Uma variação interessante e potencialmente útil na libreração da luz é fracionar a dose total de luz em séries de duas ou mais exposições separadas, cada uma delas pontuada porintervalos de tempo definidos. $O$ efeito potencial do fracionamento da dose total de luz é alcançar um maior efeito geral da TFD, mesmo sem aplicar uma quantidade maior de FS (BOLOGNIA et al., 2015). Os dados de viabilidade celular da linhagem B16F10 em séries de duas exposições separadas de TFD, mostraram que essa metodologia proporciona uma aplicação de maior quantidade de exposição a luz, sem o aumento da quantidade do FS, embora também ocorra a relação dose $x$ tempo de incubação das micelas. 


\section{REFERÊNCIAS BIBLIOGRÁFICAS}

ABASSI, Y. A.; XI, B.; ZHANG, W.; YE, P.; KIRSTEIN, S. L.; GAYLORD, M. R.; FEINSTEIN, S. C.; WANG, X.; XU, X. Kinetic Cell-Based Morphological Screening: Prediction of Mechanism of Compound Action and Off-Target Effects. Chem. Biol. 16, 712-723, 2009.

AGGARWAL, B. B.; BANERJEE, S.; BHARADWAJ, U.; SUNG, B.; SHISHODIA, S.; , G. Curcumin induces the degradation of cyclin $E$ expression through ubiquitindependent pathway and up-regulates cyclin-dependent kinase inhibitors p21 and p27 in multiple human tumor cell lines. Biochem Pharmacol., v. 73, pp. 1024-1032, 2007.

ALEXANDRIDIS, P.; HOLZWARTH, J.; HATTON, T., Macromolecules 27, 2414, 1994.

ALTAN-BONNET, G.; KRAMER, F. R. Nucleic acid hybridization: Robust sequence

ANTON, N.; VANDAMME, T.F. The universality of low-energy nano-emulsification. Int. J. Pharm. v. 377, p. 142-147, 2009.

ATIENZAR, F. A.; TILMANT, K.; GERETS, H. H.; TOUSSAINT, G.; SPEECKAERT, S.;HANON, E.; DEPELCHIN, O.; DHALLUIN,S. The Use of Real-Time Cell Analyzer Technology in Drug Discovery: Defining Optimal Cell Culture Conditions and Assay Reproducibility with Different Adherent Cellular Models. Society for Laboratory Automation and Screening, 2011.

ATTWOOD, D.; COLLETT, J.H.; TAIT, C.J. The Micellar Properties of The Poly( oxyethylene) -poly( oxypropylene) Copolymer Pluronic F127 in Water and Electrolyte Eolution. Internutionul Journal of Pharmaceutics, 26 25-33, 1985.

BADER, H.; RINGSDORF, H.; SCHMIDT, B. Water soluble polymers in medicine, Angew. Makromol. Chem. 123/124 (1984) 457-485.

BARNHILL, R. L.; LEVY, M. A. Regressing thin cutaneous malignant melanomas (< or $=1.0 \mathrm{~mm}$ ) are associated with angiogenesis. Am J Pathol. v. 143, n.1, pp. 99-104, 1993.

BASAK, R.; BANDYOPADHYAY, R. Encapsulation of Hydrophobic Drugs in Pluronic F127 Micelles: Effects of Drug Hydrophobicity, Solution Temperature, and Ph. Langmuir, v. 29, p. 4350 4356, 2013. 
BATRAKOVA, E. V.; Li, S.; ELMQUIST, W. F.; MILLER, D. W.; ALAKHOV, V. Y.; KABANOV,A. V. Mechanism of sensitization of MDR cancer cells by Pluronic block copolymers: Selective energy depletion. British Journal of Cancer., v. 85, n. 12, p. 1987-199, 2001.

BATRAKOVA, E.; LI, S.; BRYNSKIKH, A. M.; SHARMA, A. K.; LI, Y.; BOSKA, M.; GONG, N.; MOSLEY, R. L.; ALAKHOV, V. Y.; GENDELMAN, H. E.; KABANOV, A. V. Effects of pluronic and doxorubicin on drug uptake, cellular metabolism, apoptosis and tumor inhibition in animal models of MDR cancers. Journal of Controlled Release., v. 143, n. 3. pp. 290-301, 2010.

BATRAKOVA, E. V.; KABANOV, A. V. Review Pluronic block copolymers: Evolution of drug delivery concept from inert nanocarriers to biological response modifiers. / Journal of Controlled Release., v. 130, pp. 98-106, 2008.

BECHET, D.; COULEAUD, P.; FROCHOT, C.; VIRIOT, M.L.; GUILLEMIN, F.; BARBERI-HEYOB, M. Nanoparticles as vehicles for delivery of photodynamic therapy agents. Trends Biotechnol. v. 26, n.11, pp. 612-621, 2008.

BRAKMANE, G.; WINSLET, M.; SEIFALIAN, A. M. Systematic review: the applications of nanotechnology in gastroenterology. Alimentary Pharmacology \& Therapeutics, v. 36, n. 3, p. 213-221, 2012.

BOHORQUEZ, M.; KOCH, C.; TRYGSTAD, T.; PANDIT, N. A Study of the Temperature-Dependent Micellization of Pluronic F127. Journal of Colloid and Interface Science, v, 216,pp. 34-40, 1999.

BOLOGNIA, J; JOSEPH L.; JORIZZO, JULIE V. SCHAFFER. Dermatologia. Medical, pp.135, 2015.

BONETT, R. M.; HOOPFER, E. D.; DENVER, R. J. Molecular mechanisms of corticosteroid synergy with thyroid hormone during tadpole metamorphosis. General and Comparative Endocrinology, v. 168, In. 2, pp. 209-219, 2010.

BOISSY, R. E. The melanocyte. Its structure, function, and subpopulations in skin, eyes, and hair. Dermatologic Clinics.,v. 6(2), p. 161-173, 1988.

CALVO, P.; REMUNAN-LOPEZ, C.; VILA-JATO, J. L.; ALONSO, M. J.; Colloid Polym. Sci., v. 275, n. 46, 1997.

CALVO, P.; VILA-JATO, J. L.; ALONSO, M. J.; J. Pharm. Sci., v. 85, pp. 530, 1996.

CALZAVARA-PINTON, P.; VENTURINI, M.; SALA, R. Photodynamic therapy: update 2006 Part 2: Clinical results. Journal of the European Academy of Dermatology and Venereology., 2007. 
CANCER

RESEARCH

UK

MANCHESTER

INSTITUTE.

www.cruk.manchester.ac.uk/.

CARINA SILVA DE PAULA. Desenvolvimento e Caracterizacao Fotofisica de Nanoestruturas Contendo AICIPc para a Terapia Fotodinâmics, 2014.

CHEN, W.; PENG, J.; SU, Y.; ZHENG, L.; WANG, L.; JIANG, Z. Separation of oil/water emulsion using Pluronic F127 modified polyethersulfone ultrafiltration membranes Separation and Purification Technology, v. 66, n. 3,7 , pp. 591597, 2009.

CHEN, W.; PENG, J.; SU, Y.; ZHENG, L.; WANG, L.; JIANG, Z. Separation of oil/water emulsion using Pluronic F127 modified polyethersulfone ultrafiltration membranes Separation and Purification Technology, v. 66, n. 3, 7 , pp. 591597, 2009.

CHIN, L.; MERLINO, G.; DEPINHO, R. A. Malignant melanoma: modern black plague and genetic black box. GENES \& DEVELOPMENT, v. 12, pp. 34673481, 1998.

CHU, B.; ZHOU, Z. Surf. Sci. Ser. 60, 67, 1996.

CILIA, R.; KO, J. H.; CHO, S. S.; VAN EIMEREN, T.; MAROTTA, G.; PELLECCHIA, G.; PEZZOLI, G.; ANTONINI, A.; STRAFELLA, A. P. Reduced dopamine transporter density in the ventral striatum of patients with Parkinson's disease and pathological gambling. Neurobiology of Disease., v. 39, p. 98-104, 2010.

CHUDNOVSKY, Y.; KHAVARI, P. A.; ADAMS, A. E. Melanoma genetics and the development of rational therapeutics. The Journal of Clinical Investigation, $v$. 115, n. 4, 2005.

COGHLIN, C.; MURRAY, G. I. Review Current and emerging concepts in tumour metastasis. The Journal of Pathology., v. 222, n. 1, p. 1-15, 2010.

CUENCA, C. M. R. Trabalho de Conclusão de Curso em Química como requisito parcial à obtenção do título de Bacharel em Química. Micelas Poliméricas Termorreverssíveis como Sistemas para Liberação Modificada de Fármacos por via Tópica. Centro de Ciências Naturais e Humanas- UFABC, 2013.

CZERSKA, M.; MIKOLAJEWSKA, K.; ZIELINSKI, M.; GROMADZINSKA, J.; WASOWICZ, W. Współczesne markery stresu oksydacyjnego. Med $\operatorname{Pr}, \mathrm{v}$. 66, n. 3, pp. 393-405, 2015. 
DAVIDS, L. M.; KLEEMANN, B. Combating melanoma: The use of photodynamic therapy as a novel, adjuvant therapeutic tool. Cancer Treat. Rev. v. 37, pp. 465-475, 2011.

DETTY, M. R.; GIBSON, S. L.; WAGNER, S. JCurrent clinical and preclinical photosensitizers for use in photodynamic therapy. J Med Chem., v. 29, n.47(16), p. 3897-915, 2004.

DEUTSCH, G. B.; KIRCHOFF, D. D.; FARIES, M. B. Metastasectomy for Stage IV Melanoma. Surgical Oncology Clinics of North America., v. 24, n. 2, p. 279-298, 2015.

DING, H.; YU, H.; DONG, Y.; TIAN, R.; HUANG, G.; BOOTHMAN, D. A.; GAO, J. Photoactivation switch from type II to type i reactions by electron-rich micelles for improved photodynamic therapy of cancer cells under hypoxia. Journal of Controlled Release, 156(3), p. 276-280, 2011.

DONATI, P.; PAOLINO, G.; DONATI, M.; PANETTA, C. Cutaneous mastocytosis combined with eruptive melanocytic nevi and melanoma. Coincidence or a linkage in the pathogenesis? J Dermatol Case Rep, v. 3, pp. 70-74, 2014.

DURMUS, M.; AHSEN, V. Water-soluble cationic gallium(III) and indium(III) phthalocyanines for photodynamic therapy. Journal of Inorganic Biochemistry., $v$. 104, p. 297-309, 2010.

EDWARDS, L.; GOUTERMAN, M. Porphyrins XV. Vapor absorption spectra and stability: phthalocyanines. J. Mol. Specr. 33, 293-310, 1970.

ELDER, D. E. "Metastatic melanoma." Pigment cell, v. 8, pp. 182-204, 1987.

ESCOBAR-CHÁVEZ, J. J.; M. LÓPEZ-CERVANTES, A.; NAĪK, Y. N.; QUINTANARGUERRER, K. D.; GANEM-QUINTANAR, A. Pharm Pharmaceut Sci; v. 3, pp. 339-358, 2006.

FALEIROS, R. R.; LEISE, B. B.; WESTERMAN, T.; YIN, C.; NUOVO, G. J.; BELKNAP, J. K. In vivo and in vitro evidence of the involvement of CXCL1, a keratinocyte-derived chemokine, in equine laminitis. Journal of Veterinary Internal Medicine / American College of Veterinary Internal Medicine., v. 23(5), pp. 1086-96, 2009.

FAROKHZAD, O.; Langer, R. Impact of nanotechnology on drug delivery. Acs Nano, v. 3, n. 1, pp. 16-20, 2009.

FAYTER, D.; CORBETT, M.; HEIRS, M.; FOX, D.; EASTWOOD, A. A systematic review of photodynamic therapy in the treatment of pre-cancerous skin 
conditions, Barrett's oesophagus and cancers of the biliary tract, brain, head and neck, lung, oesophagus and skin. NIHR Journals Library, 2003.

FARRELL, T. S. C. Reflective Language Teaching: From Research to Practice, 2015.

FENG, S. S.; ZHAO, L.; ZHANG Z et al. "Chemotherapeutic engineering: vitamin E TPGS-emulsified nanoparticles of biodegradable polymers realized sustainable paclitaxel chemotherapy for $168 \mathrm{~h}$ in vivo," Chemical Engineering Science., v. 62, n. 23, pp. 6641-6648, 2007.

FERRARI, M.; ROCHA-FILHO, P. A. Multiple emulsions containing amazon oil: açaí oil (Euterpe oleracea). Braz. J. Pharmacog. v. 21, 2011.

FESSI, H.; PUISIEUX, F.; DEVISSAGUET, J-PH.; AMMOURY, N.; BENITA, S.; Int. J. Pharm. 1989, 55, r1.

FIDLER, I. J.; BUCANA, C. Lymphocytes Mechanism of Tumor Cell Resistance to Lysis by Syngeneic. Cancer Res; v. 37, pp. 3945-3956, 1977.

FIGUEIREDO, L. C.; CORDEIRO, L. N.; ARRUDA, A. P.; DENISE, M.; CARVALHO, F.; MARQUES, E.; COUTINHO, M. Câncer de pele: estudo dos principais marcadores moleculares do melanoma cutâneo Skin cancer: main molecular markers of cutaneous melanoma. Revisão de Literatura Câncer de Pele, 49(3), p. 179-183, 2003.

FINSEN, N. R. The red-light treatment of small-pox. is the trea tment of small-pox patients in broad daylight warrantablet. The British Medical Journal,1903.

FITZPATRICK. Tratado de Dermatologia. 7. Ed. Rio de Janeiro: Revinter, 2011.

FONSECA, C.; SIMOES, S.; GASPAR, R. Paclitaxel-loaded PLGA nanoparticles: preparation, physicochemical characterization and in vitro anti-tumoral activity. $J$ Control Release., v. 83, n. 2, pp. 273-286, 2002.

FOSTER, B.; COSGROVE, T.; ESPIDEL, Y. PFGSE-NMR study of pHtriggered behavior in Pluronic-lbuprofen solutions. Langmuir, v. 25, n. 12, pp. 6760, 2009.

FRANKE, J. C.; PLOTZ , M. A.; PROKOP, GEILEN, C. C.; SCHMALZ, H-G.; EBERLE, J. New caspase-independent but ROS-dependent apoptosis pathways are targeted in melanoma cells by an iron-containing cytosine analogue. Biochemical Pharmacology, v. 79, pp. 575-586, 2010.

FRYD, M. M.; MASON, T. G. Advanced Nanoemulsions. Annu. Rev. Phys. Chem. v. 
63, p. 493-518, 2012.

GARBE, C.; EIGENTLER, T. H.; KEILHOLZ, U.; HAUSCHILD, A.; KIRKWOOD, J. M. Systematic Review of Medical Treatment in Melanoma: Current Status and future Prospects. Oncologsti, v. 16, n. 1, pp. 5-24, 2011.

GARCIA-FUENTES, M.; ALONSO, M. J. Chitosan-based drug nanocarriers: Where do we stand? Journal of Controlled Release., v. (2), pp 496-504, 2012.

GEMMA, N.; JIAYI, P.; TORCHILIN, V. P. Micelle-like Nanoparticles as Carriers for DNA and siRNA. Mol. Pharmaceutics, v. 12,pp. 301 313, 2015.

GIL, E. S.; HUDSON, S. M. Stimuli-reponsive polymers and their bioconjugates. Progress in Polymer Science v. 29, n. 12, pp. 1173-1222, 2004.

GILISSEN, M. J.; VAN DE MERBEL-DE WIT, L. E.; STAR, W. M.; KOSTER, J. F.; SLUITER, W. Effect of photodynamic therapy on the endothelium-dependent relaxation of isolated rat aortas. Cancer Res. 53, 2548-52, 1993.

GON, A. S.; MINELLI, L.; GUEMBAROVSKI, A. L. Melanoma cutâneo primário em Londrina. An Bras Dermatol; v. 76, n. 4, pp. 413-26, 2001.

GONZÁLEZ, N.; PRIN, J. L.; BENÍTEZ, J. L.; RAMÍREZ, A.; GARCÍA, A.; RAMIREZ, M.;SABINO, M. A.; GÁSCUE, B. R. D. Estudio de la cinetica de difusion en hidrogeles sintetizados a partir de acrilamida-co-ácido acrílico con turba y almidón via calentamiento convencional y bajo radiación microondas. Rev. LatinAm. Metal. Mat., v. 32, n. 1, pp. 136-144, 2012.

GOYDOS, J. S.; MANN, B.; KI, H. J.; GABRIEL, E. M.; ALSINA, J.; GERMINO, F. J.; SHIH, W.; GORSKI, D. H. Detection of B-BRAF and N-RAS mutations in human melanoma. J. AM Coll Surg ., v. 200, n. 3, p. 362-370, 2005.

GMEINER, W. H.; GHOSH, S. Nanotechnology for cancer treatment. Nanotechnology Reviews., v. 3, n. 2, p. 111-122, 2014.

GROVER, G. J.; DZWONCZYK, S.; PARHAM, C. S.; The endothelin-1 receptor antagonist BQ-123 reduces infarct size in a canine model of coronary occlusion and reperfusion. Cardiovascular Research, v. 27, pp.1613-1618, 1993.

GUPTA, P. B.; KUPERWASSER, C.; BRUNET, J. P. The melanocyte differentiation program predisposes to metastasis after neoplastic transformation. Examines the melanocyte as the source of aggressiveness of melanoma. Nat Genet, v. 37 n. 10, pp. 1047-1054, 2005. 
HAASS, N. K.; HERLYN, M. Normal Human Melanocyte Homeostasis as Paradigm for Understanding Melanoma. J. Inventig Dermatol Symp Proc, v. 10, n. 2, pp. 153-163, 2005.

HOFFMAN, A. S.; STAYTON, P. S.; VOLGA, B.; CHEN, G.; CHEN, J.; CHEUNG, C.; CHILKOTI, A.; DING, L.; DONG, R.; FONG, C. A.; LACKEY, C. J.; LONG, M.; MIURA, J. E.; MORRIS, N.; MURTHY, Y.; NABESHIMA, T. G.; PARK, O. W.; PRESS, T.; SHIMOBOJI, S.; SHOEMAKER, H. J.; YANG, N.; MONJI, R. C.; NOWINSKI, C. A.; COLE, J. H.; PRIEST, J. M.; HARRIS, K.; NAKAMAE, T.; NISHINO, T.; MIYATA, T. Really smart bioconjugates of smart polymers and receptor proteins, J. Biomed. Mater. Res, v. 52, pp. 577-586, 2000.

HANAHAN, D.; WEINBERG, R. A. Review The Hallmarks of Cancer. Cell.; v. 100, n. 1,7 p. $57-70,2000$.

HOLLAND, R.; PARKER, E.; GUINEY, K.; ZELD, F.; J. Phys. Chem.,v. 99, pp. 11981, 1995.

HOU, J. L. B. A.; REED, K. B.; KNUDSON, R. M.; MIRZOYEV, S. A.; LOHSE, C. M.; FROHM, M. L.; BREWER, J. D.; OTLEY, C. C.;ROENIGK, R. K. Dermatologic Surgery., v. 41, n. 2 - p. 211-218, 2015.

HSU, M-Y.; MEIER, F.; HERLYN, M. Melanoma development and progression: a conspiracy between tumor and host. Differentiation, v. 70, n. 9-10, pp. 522536, 2002.

HU, C. M.; ZHANG, L. Nanoparticle-based combination therapy toward overcoming drug resistance in cancer. Biochem Pharmacol. v. 83, n.8, pp. 1104-1111, 2012.

INSTITUTO NACIONAL DE CÂNCER José Alencar Gomes da Silva (INCA). Estimativa 20146incidência de câncer no Brasil. Rio de Janeiro (2016).

ISO TC 229 (INTERNATIONAL, 2005),

JEMAL, A.; BRAY, F.; CENTER, M M.; FERLAY, J.; WARD, E.; FORMAN, D. Global Cancer statistics. CA: A Cancer Journal for Clinicians., v. 61, $\mathrm{n}$. 2, p. 69-90, 2011.

JHAVERI, A. M.; TORCHILIN, V. P. Multifunctional polymeric micelles for delivery of drugs and siRNA. FrontiersinPharmacology PharmacologyofAnti-CancerDrugs, v. 5, n. 77, pp. 1-26, 2014.

JIN, Y.; ZHANG, X.; ZHANG, B.; KANG, H.; DU, L.; LI, M. Nanostructures of an amphiphilic zinc phthalocyanine polymer conjugate for photodynamic therapy of psoriasis. Colloids and Surfaces B: Biointerfaces. , 128, p. 405-409, 2015. 
JONES, C.; COOPER, M.; MANG, T. S.; WILSON, B. D.; STOLL,H. L.; J. Am. Acad. Dermatol., v. 27, pp. 979, 1992.

JONES, M. C.; LEROUX, J.-C. Polymeric micelles - a new generation of colloidal drug carriers. Eur. J. Pharm. Biopharm., v. 48, pp. 101-111, 1999.

JORIS, F.; MANSHIAN, B. B.; PEYNSHAERT KAREN.; DE SMEDT, S. C.; BRAECKMANSAD, K.; SOENENA, S. J. Assessing nanoparticle toxicity in cellbased assays: influence of cell culture parameters and optimized models for bridging the in vitro-in vivo gap. Chem. Soc. Rev., v. 42, n.8339, 2013.

KANG, I-C.; KIM, D-S.; JANG, Y.; CHUNG, K-H. Suppressive Mechanism of Salmosin, a Novel Disintegrin in B16 Melanoma Cell Metastasis. Biochemical and Biophysical Research Communications., v. 275, n. 1, p. 169-173, 2000.

KANO, A.; TANIWAKI, Y.; NAKAMURA, I.; SHIMADA, N.; MORIYAMA, K. Tumor delivery of Photofrin ${ }^{\circledR}$ by PLL-g-PEG for photodynamic therapy. J. C ontrol. Release. v. 167, p. 315-21, 2013.

KÄSTLE, M.; GRIMM, S.; NAGEL,R.; BREUSING, N.; GRUNE, T. Combination of PDT and inhibitor treatment affects melanoma cells and spares keratinocytes. Free Radical Biology and Medicine, v. 50, n. 2, pp. 305-312, 2011.

KESSEL, D.; LUO, Y. Mitochondrial photodamage and PDT-induced apoptosis. J.Photochem. Photobiol. B: Biol. v. 42, p. 89-95, 1998.

KOLAROVA, H.; LENOBEL, R.; KOLAR, P.; STRNAD, M. Sensitivity of different cell lines to phototoxic effect of disulfonated chloroaluminium phthalocyanine. Toxicology in Vitro: An International Journal Published in Association with BIBRA, v. 21, n. 7, pp.1304-1306, 2007a.

KOLAROVA, H.; NEVRELOVA, P.; BAJGAR, R.; JIROVA, D.; KEJLOVA, K.; STRNAD, M. In vitro photodynamic therapy on melanoma cell lines with phthalocyanine. Toxicology in Vitro., v. 21, 2, pp. 249-253, 2007b.

LANGMACK, K.; MEHTA, R.; TWYMAN, P.; NORRIS, P. Topical photodynamic therapy at low fluence rates--theory and practice. J. Photochem. Photobiol. B: Biol. v. 60, p. 37-43 2001.

LEGRAND, P.; BARRATT, G.; MOSQUEIRA, V.; FESSI, H.; DEVISSAGUET, J-Ph.; S.T.P. Pharma Sci., v. 9, n. 411, 1999.

LEVY, A. P.; LEVY, N. S.; GOLDBERG, M. A. Post-transcriptional Regulation of Vascular Endothelial Growth Factor by Hypoxia. The Journal of Biological Chemistry, v. 271, pp. 2746-2753, 1996. 
LI, G.; SATYMOORTHY, K.; HERLYN, M. N-Cadherin-mediated Intercellular Interactions Promote Survival and Migration of Melanoma Cells. CANCER RESEARCH, v. 61,PP. 3819-3825, 2001.

LIM, J.; HIPPALGAONKAR, K.; ANDREWS, S. C.; MAJUMDAR, A.; YANG, P. Quantifying Surface Roughness Effects on Phonon Transport in Silicon Nanowires. Nano Lett., v. 12, n. 5, p. 2475-2482, 2012.

LIU, X. Partitioning of amphiphilic and charged molecules on polymeric surfaces by physisorption. A dissertation submitted to the Graduate Faculty of North Carolina State University, 2011.

LONGO, J. P. F.; LOZZI, S. P.; SIMIONI, A. R.; MORAIS, P. C.; TEDESCO, A. C., AZEVEDO, R. B. Photodynamic Therapy with aluminum-chloro-phtalocyanine induces necrosis and vascular damage in mice tongue tumors. Journal of Photochemistry and Photobiology B: Biology, v. 94, pp. 143-146, 2009.

MCCAUGHAN, JR.; J. S.; GUY, J. T.; HICKS, W.; LAUFMAN, L.; NIMS, T. A.; WALKER, J.; Arch. Surgery, v. 124, pp. 211, 1989.

MACDONALD, I. J.; DOUGHERTY, T. J. Basic principles of photodynamic therapy. Journal of Porphyrins and Phthalocyanines., 5, p. 105-129, 2011.

MACHADO, A. E. H. terapia fotodinâmica: princípios, potencial de aplicação e perspectivas. QUÍMICA NOVA, v. 23, n. 2, 2000.

MADURAY, K.; KARSTEN, A.; ODHAV, B.; NYOKONG, T. In vitro toxicity testing of zinc tetrasulfophthalocyanines in fibroblast and keratinocyte cells for the treatment of melanoma cancer by photodynamic therapy. J. Photochem. Photobiol. B: Biol., v.103, n. 2, p. 98-104, 2011.

MANDAL, B. B.; KUNDU, S. C. Self-assembled silk sericin/poloxamer nanoparticles as nanocarriers of hydrophobic and hydrophilic drugs for targeted delivery. Nanotechnology., v. 20, n. (35), pp. 355101, 2009.

MCMAHON, K. S.; WIEMAN, T. J.; MOORE, P. H.; FINGAR, V. H. Effects of photodynamic therapy using mono-l-aspartyl chlorin e6 on vessel constriction, vessel leakage and tumor response. Cancer Res. 54, 5374—5379, 1994.

MAFTOUM-COSTA, M.; NAVES, K.; OLIVEIRA, A.; TEDESCO, A.; DASILVA, N.,; PACHECO-SOARES, C. Mitochondria, endoplasmic reticulum and actin filament behavior after PDT with chloroaluminum phthalocyanine liposomal in HeLa cells. Cell Biology International., 32(8), p. 1024-1028, 2008. 
MAGDER, S. Reactive oxygen species: toxic molecules or spark life? Critical Care, v.10, n.1, 2006, p. 1-8, 2006.

MAGENHEIM, B.; BENITA; S.; S.T.P. Pharma Sci., v. 1, n. 221, 1991.

MAJUMDAR, A. Bioassays based on molecular nanomechanics. Disease Markers., 18(4), p. 167-174, 2002.

MANDAL, B. B.; KUNDU, S. C. (2009). Self-assembled silk sericin/poloxamer nanoparticles as nanocarriers of hydrophobic and hydrophilic drugs for targeted delivery. Nanotechnology. 20 (35): 355101.

MARITIM, A. C.; SANDERS, R. A.; WATKINS, J. B. Diabetes, oxidative stress, and antioxidants: a review. J Biochem Mol Toxicol., v.17, n. 1, pp 24-38, 2003.

MASTER, A. M.; QI, Y.; OLEINICK, N. L.; GUPTA A.S. EGFR-mediated intracellular delivery of Pc 4 nanoformulation for targeted photodynamic therapy of cancer: in vitro studies. Nanomedicine: Nanotechnology, Biology and Medicine. v. 8, p. 655-64, 2012.

MARTINS, J.; ALMEIDA, L.; LARANJINH, J. Simultaneous Production of Superoxide Radical and Singlet Oxygen by Sulphonated Chloroaluminum Phthalocyanine Incorporated in Human Low-density Lipoproteins: Implications for Photodynamic Therapy. Photochemistry and Photobiology., v. 80, n. 2, p. 267-273, 2004.

MEYER-BETZ, F. Research on the biological (photodynamic) action of hematoporphyrin and other derivatives of blood and bile pigments. Deutsches Archiv. fur Klinische. Medizin., v. 112, p. 476-503, 1913.

MACDONALD, J. S.; ROBERTSON, R. T. Toxicity Testing in the 21st Century: A View from the Pharmaceutical Industry. Toxicol. Sci., v. 110, pp. 40-46, 2009.

MOGHIMI, S. M.; HUNTER, A. C. (Poloxamers and poloxamines in nanoparticle engineering and experimental medicine. Trends Biotechnol., v.18, n. 10, pp. 412-420, 2000.

MOSMANN, T. Rapid colorimetric assay for cellular growth and survival: application to proliferation and cytotoxicity assays. J Immunol Methods., v. 65, pp. 55-63, 1983.

MODY, V.; SIWALE, R.; SINGH, A.; Mody, H. Introduction to metallic nanoparticles. J Pharm Bioallied Sci., v. 2(4), pp. 282-289, 2010. 
MONGE-FUENTES, V. TESE DE DOUTORADO. Terapia fotodinâmica mediada por nanoemulsão à base de óleo de açaí (Euterpe oleraceae Martius) para o tratamento de melanoma in vitro e in vivo, 2014.

MOSQUEIRA, V. C. F.; LEGRAND, P.; PINTO-ALPHANDARY, H.; PUISIEUX, F.; BARRATT, G.; J. Pharm. Sci., v. 89, n. 614, 2000.

MUELLER, D. W.; BOSSERHOFF, A.K. "Role of miRNAs in the progression of malignant melanoma". Br J Cancer, v. 101, n. 4, 2009.

NATIONAL CANCER INSTITUTE. New analysis of breast cancer subtypes could lead to better risk stratification; Annual Report to the Nation shows that mortality and incidence for most cancers continue to decline. NCI Press Release, 2015.

NUNES, X. P. Biological Oxidations and Antioxidant Activity of Natural Products. Phytochemicals as Nutraceuticals - Global Approaches to Their Role in Nutrition and Health, 1-21, 2012.

NURIMAR, C. F.; CALMON, R.; MACEIRA, J. P.; CUZZI, T.; CESAR, S. SILVA, C. Melanoma cutâneo: estudo prospectivo de 65 casos. An. Bras. Dermatol., v.80, n.1, 2005.

O'CONNOR, A. B.; DWORKIN, R. H. Treatment of Neuropathic Pain: An Overview of Recent Guidelines. The American Journal of Medicine, v. 122, n.10, S22-S32, 2009.

OCHEKPE, N. A.; OLORUNFEMI, P.O.; NGWULUKA, N. C. Nanotechnology and Drug Delivery Part 1: Background and Applications. Trop J Pharm Res, v. 8, n. 3, pp. 265-274, 2009.

Organização Mundial de Saúde (OMS). www. who.int.

PEER, D.; KARP J. M.; HONG, S.; FAROKHZAD, O. C.; MARGALIT, R.; LANGER, R. Nanocarriers as an emerging platform for cancer therapy. Nature Nanotechnology, v. 2, pp. $751-760,2007$.

PIETTE, J.; VOLANTI, C.; VANTIEGHEM, A.; MATROULE, J-Y.; HEBRAKEN, Y.; AGOSTINIS, P. Cell death and growth arrest in response to photodynamic therapy with membrane-bound photosensitizers. Apoptosis - from Signalling Pathways to Therapeutic Tools Biochemical Pharmacology, v. 66, n. 8, pp. 1651-1659, 2003.

PLAETZER, K.; KIESSLICH, T.; VERWANGER, T. KRAMMER, B. The Modes of Cell Death Induced by PDT: An Overview. Medical Laser Application, v. 18, 1, pp. 7-19, 2003. 
PORTILHO, F. A.; CAVALCANTI, C. E. D. O.; MIRANDA-VILELA, A. L.; ESTEVANATO, L. L. C.; LONGO, J. P. F.; ALMEIDA SANTOS, M. D. F. M.; LACAVA, Z. G. M. Antitumor activity of photodynamic therapy performed with nanospheres containing zinc-phthalocyanine. Journal of Nanobiotechnology, 11, 41, 2013.

PRASSAD, K.; LUONG, T.; FLORENCE, A.; PARIS, J.; VAUTION, C.; SEILLER, M.; AND PUISIEUX, F.; J. Colloid Interface Sci. 69, 225 (1979).

PREMI, S. et al. Chemiexcitation of melanin derivatives induces DNA photoproducts long after UV exposure. Science. v. 347, n. 6224, p. 842-47. 2015.

POZO-INSFRAN, D.; BRENES, C.H.; TALCOTT, S. T. Phytochemical Composition and Pigment Stability of Açai (Euterpe oleracea Mart.). J. Agric. Food Chem. v. 52,1539 1545, 2004.

PULIDO, J. Z. Melanoma Maligno. Rev. Bras. Oncologia Clínica., v. 4, n. 11, p. 2529, 2007.

RASSING, J.; MACKENNA, W.; BANDOPADHYAY,S.; EYRING, E. Ultrasonic and 13C-nmr studies on gel formation in aqueous solutions of the ABA block polymer Pluronic-127, J.Mol. Liquid., 27, 165-178, 1984.

RASSING, J.; ATWOOD, D. Ultrasonic velocity and ligth scattering studies on polyoxyethylene-polyoxypropylene copolymer Pluronic F-127 in aqueous solution, Int. J. Pharm., 13, 47-55, 1983.

RAUF, M. A.; HISAINDEE, S.; GRAHAM, J.P.; NAWAZ, M. Solvent effects on the absorption and uorescence spectra of $\mathrm{Cu}$ (II) - phthalocyanine and DFT calculations. J Mol Liq 168: 102-109, 2012.

RICO, C. I.; RODRÍGUEZ, J.; CONDE, C. A.; MANTILLA, J. C.; ESCOBAR, P. Skin permeation and biodistribution of chloroaluminum phthalocyanine (CIAIPC) nanoemulsion applied topically in Wistar rats. Rev. Argent. Dermatol., v .94, n. 2, 2013.

ROBERTSON, C. A. THE EFFICACY OF PHOTODYNAMIC THERAPY ON HUMAN MALIGNANT MELANOMA CELLS, 2010.

RONSEIN, G. E.; MIYAMOTO, S.; BECHARA, E.; DI MASCIO, P.; MARTINEZ, G. R. Oxidação de proteínas por oxigênio singleto: Mecanismos de dano, estratégias para detecção e implicações biológicas. Quimica Nova, 29(3), p. 563-568, 2006.

SANTA, C.F.; OSORIO, B. I. L. Materiales poliméricos en nanomedicina: transporte y liberación controlada de fármacos. Rev. Acad. Colomb. Cienc. v. 37, n. 142, pp. 115-124, 2013. 
SIBAUD,V.; RESSEGUIER, S.; RADUT, R.; ATTAL, J.; MEYER, N.; DELORD, J. P.Correction to "Nanovectorization of TRAIL with Single Wall Carbon Nanotubes Enhances Tumor Cell Killing". Acute skin reaction suggestive of pembrolizumab-induced radiosensitization. Melanoma Res, 2015.

SILVEIRA-LACERDA, E. P.; VILA-NOVA, C. A. S. T.; PEREIRA, F. C.; HAMAGUCHI, A.; PAVANIN, L. A.; GOULART, L. R.; HOMSIBRANDEBURGO, M. I.; SOARES, A. M.; SANTOS, W. B;NORMIZO, A. The ruthenium complex cis (chloro) tetraammineruthenium (III) chloride immune stimulatory activity on human peripheral blood mononuclear cells. Biol Trace Elme Res., 2009.

SCHAFFAZICK, S. R. ; GUTERRES, S. S.; FREITAS, L. DE L; POHLMANN, A. R. Caracterização e estabilidade físico-química de sistemas poliméricos nanoparticulados para administração de fármacos. Quim. Nova, v. 26, n. 5, pp. 737, 2003.

SCHERLUND, M.; BRODIN, A.; MALMSTEN, M. Micellization and gelation in block copolymer systems containing local anesthetics. Int. J.Pharm, v. 37, 2000.

SCHMOLKA, R. Physical basis for poloxamer interactions, Ann. N. Y. Acad. Sci.,720, pp. $-97,1994$.

SCHMERLING, R. A.; BUZAID, A. C. encontro anual da american society of clinical oncology (asco) Onco \&, 2013.

SCHWEITZER, V. G.; VISSCHER, D.; Otolaryngol. Head NeckSurg., v. 102, pp. 639, 1990.

SHAPIRO, D. M.; FUGMANN, R. A. A Role for Chemotherapy as an Adjunct to Surgery The Journal of Cancer Research, pp. 1098-1101, 1957.

SOCIEDADE BRASILEIRA DE DERMATOLOGIA. www. sbd. org.br

SOLĖ, I.; SOLANS, C.; MAESTRO, A.; GONZALEZ, C.; GUTIERREZ, J. M. Study of nano-emulsion formation by dilution of microemulsions. J. Colloid Interface Sci. v.376, p. 133-139, 2012.

SULAIMON, S. S.; KITCHELL, B. E. Review article the biology of melanocytes. Veterinary Dermatology, v. 14, 2, pp. 57-65, 2003a.

SULAIMON, S. S.; KITCHELL, B. E. The basic biology of malignant melanoma: molecular mechanisms of disease progression and comparative aspects. 
Journal of Veterinary Internal Medicine / American College of Veterinary Internal Medicine, v. 17, pp.760-772, 2003b.

SPILLER, W.; KLIESCH, H.; WOHRELE, D.; HACKBARTH, S.; RODER, B.; SCHNURPFEIL, G. Singlet oxygen quantum yields of different photosensitizers in polar solvents and micellar solutions. Journal of Porphyrin Phytalocianines, 2(2), pp.145-158, 1998.

SWAMI, A.; SHI, J.; GADDE, S.; VOTRUBA, A.; KOLISHETTI, N.; FAROKHZAD, O. Nanoparticles for Targeted and Temporally Controlled Drug Delivery. In: Svenson S, Prud'homme RK, eds. Multifunct ional Nanoparticles for Drug Delivery Applications: Springer US: 9-29, 2012.

TAILLEFER, J.; BRASSEUR, N.; VAN LIER, J. E.; LENAERTS, V.; LE GARREC D.; LEROUX, J.C. In-vitro and in-vivo evaluation of $\mathrm{pH}$-responsive polymeric micelles in a photodynamic cancer therapy model. Journal of Pharmacy and Pharmacology, v. 53, pp.155 $\pm 166,2001$.

TAILLEFER, J.; JONES, M. C.; BRASSEUR, N.; VAN LIER, J. E.; LEROUX, J. C. Preparation and characterization of $\mathrm{pH}$-responsive polymeric micelles for the delivery of photosensitizing anticancer drugs. J. Pharm. Sci., v. 89, pp. 52-62, 2000.

TANDON, V.; Bhagavatula, S. K.; Nelson, W. C.; Kirby, B. J.; Electrophoresis, v. 29, n. 109, 2008.

TORCHILIN, V.P. Structure and design of polymeric surfactant-based drug delivery systems. J Control Release., v. 73, n. (2-3), pp. 137-172, 2001.

TSAO, H.; CHIN, L.; GARRAWAY, L. A.; FISCHER, D. E. Melanoma: from mutations to medicine. Genes \& Development, v. 26, p. 1131-1155, 2015.

TURRO, N.; CHUNG, C. Macromolecules, v. 17, pp. 21231984.

VAN-BEEK, E.; BALM, A.; NIEWEG, O.; HAMMING-VRIEZE, O.; LOHUIS, P. C. KLOP, W. M. Treatment of Regional Metastatic Melanoma of Unknown Primary Origin. Cancers., 7(3), p. 1543-1553, 2015.

VROUENRAETS, M.B.; VISSER, G.W.M.; SNOW, G.B.; VAN DONGEN, G.A.M.S. Basic principles, applications in oncology and improved selectivity of photodynamic therapy, Anticancer Res., v. 23, pp. 505-522, 2003. 
WAINWRIGHT, M. Photodynamic Therapy: The Development of New Photosensitisers. Anti-Cancer Agents in Medicinal Chemistry (Formerly Current Medicinal Chemistry - Anti-Cancer Agents), v. 8, n. 3, pp. 280-291(12), 2008.

WANKA, G.; HOFFMANN, H.; ULBRICHT, W.Macromolecules, v. 27, pp. 4145, 1994.

WANG, M.; THANOUT, M. Review. Targeting nanoparticles to cancer. Pharmacological Research, v. 62, n. 2, p. 90- 99, 2010.

WILSON, B. D.; MANG, T. S.; COOPER, M.; STOLL, H.; FacialPlast. Surg. 1989, 6, 185.

WOJTOVICH, A. P.; FOSTER, T. H. Optogenetic control of ROS production. Redox Biology., 2(1), p. 368-376, 2014.

WORLD HEALTH ORGANIZATION. www.who.org.

XIAO, K.; LI, Y.; LUO, J.; LEE, J.S.; XIAO, W.; GONIK, A.M.; AGARWAL, R.G.; LAM, K.S. The effect of surface charge on in vivo biodistribution of PEG-oligocholic acid based micellar nanoparticles. Biomaterials. 32 (13): 3435-3446, 2011.

YAMAMOTO, N.; HOMMA, S.; NAKAGAWA, Y. Activation of mouse macrophages by in vivo and in vitro treatment with a cyanine dye, lumin. $J$ Photochem Photobiol B.13,295-306, 1992.

YANO, T.; HATOGAI, K.; Morimoto, H.; YODA, Y.; KANEKO, K. Photodynamic therapy for esophageal cancer. Ann Transl Med., v. 2, n. 3, p. 29, 2014.

YEE, D.; BUTTS, C.; JOY,A.; SMYLIE, M.; FENTON, D.; CHU, Q.; HANSON, J.; ROA, W. Clinical trial of post-chemotherapy consolidation thoracic radiotherapy for extensive-stage small cell lung cancer. Radiotherapy and Oncology., v. 102, n. 2, p. 234-238, 2012.

ZAKARIA, A.B.; PICAUD, F.; RATTIER, T.; PUDLO, M.; DUFOUR, F.; SAVIOT, L.; CHASSAGNON, R.; LHERMINIER, J.; GHARBI, T.; MICHEAU, O.; HERLEM, G. Antitumor activity of photodynamic therapy performed with nanospheres containing zinc-phthalocyanine. v. 12;15, n. 8, pp. 5664, 2015.

YONCHEVA, K.; CALLEJA, P.; AGUEROS, M.; PETROV, P.; MILADINOVA, I.; TSVETANOV, C.; IRACHE, J.M. Stabilized micelles as delivery vehicles for paclitaxel. Int J Pharm. v.436, n. (1-2), pp. 258-264, 2012.

SCHERLUND, M.; BRODIN, A.; MALMSTEN, M. Micellization and gelation in block copolymer systems containing local anesthetics. Int. J.Pharm., v. 211, pp. 37, 2000. 
YU, G.; DENG, Y.; DALTON, S.; ATWOOD, D.;PRICE, C.; BOOTH, C. J. Chem. Soc. Faraday Trans., 25, 2537, 1992.

PICAUD, F.; RATTIER, T.; PUDLO, M.; DUFOUR, F.; SAVIOT, L.; CHASSAGNON, R.; LHERMINIER, J.; GHARBI, T.; MICHEAU, O.; HERLEM, G. Antitumor activity of photodynamic therapy performed with nanospheres containing zincphthalocyanine., v. 12, n. 15(8), p. 5664, 2015.

ZHAO, BAOZHONG.; YIN, J- J.; BILSKI, P. J.; CHIGNELL, C. F.; ROBERTS,J. E.; HE,Y-Y. Enhanced Photodynamic Efficacy towards Melanoma Cells by Encapsulation of Pc4 in Silica Nanoparticles. Toxicol Appl Pharmacol, v. 241(2), pp. 163-172, 2009.

ZHANG, Y.; LAM, Y. M. Study of Mixed Micelles and Interaction Parameters for Polymeric Nonionic and Normal Surfactants Journal of Nanoscience and Nanotechnology, v. 6, 1-5, 2006. 